\title{
A taxonomic revision of Macrolenes (Melastomataceae)
}

\author{
A. Kartonegoro ${ }^{1,2}$, P. Hovenkamp ${ }^{1}$, P.C. van Welzen ${ }^{1,3}$ \\ ${ }^{1}$ Naturalis Biodiversity Center, P.O. Box 9517, \\ 2300 RA Leiden, The Netherlands \\ abdulrokhman.kartonegoro@naturalis.nl. \\ ${ }^{2}$ Research Center for Biology, Indonesian Institute of Sciences (LIPI), \\ Jl. Jakarta-Bogor KM.46, Cibinong 16911, Indonesia. \\ ${ }^{3}$ Institute of Biology Leiden (IBL), Leiden University, \\ P.O. Box 9505, 2300 RA Leiden, The Netherlands.
}

\begin{abstract}
Macrolenes (Melastomataceae: Dissochaeteae), a genus of woody climbers in Malesia, is taxonomically revised. Seventeen species are recognised, of which three are new to science. The genus is characterised by its scrambling habit, a pair of hair cushion domatia on the base of the leaves, axillary inflorescences, and fimbriate connective appendages on the alternipetalous stamens. An identification key, nomenclature, descriptions, typification, geographic distributions and taxonomic notes are provided. The affinities with Dissochaeta, also woody climbers, are discussed.
\end{abstract}

Keywords. Dissochaeta, Dissochaeteae, Macrolenes, Malesia, Melastomataceae, revision, taxonomy

\section{Introduction}

Macrolenes Naudin is a genus of woody climbers distributed strictly in the Malesian region. The genus is allied to Dissochaeta Blume; both are characterised by a scrambling growth habit, opposite phyllotaxy sometimes with interpetiolar outgrowths, flowers 4-merous, 2 whorls of dimorphic stamens and berry-like fruits. Macrolenes and Dissochaeta are classified in tribe Dissochaeteae (Naudin) Triana (Bakhuizen van den Brink, 1943; Maxwell, 1984; Clausing \& Renner, 2001), but are sometimes also considered to be part of tribe Miconieae (Naudin, 1851; Miquel, 1855; Renner, 1993). The last complete revision of Macrolenes was by Bakhuizen van den Brink (1943) and some notes were published by Nayar (1980). The species occurring in Thailand were revised by Renner et al. (2001), who regarded Macrolenes as a synonym of Dissochaeta.

A molecular phylogenetic study (Clausing \& Renner, 2001) showed that a woody climbing or scrambling growth habit evolved only once in the Southeast Asian Melastomataceae, and that the two species of Macrolenes analysed form a clade with two species of Dissochaeta and two of Diplectria. So far, however, only these six species were sampled for phylogenetic analysis and a denser sampling is required for a more confident differentiation between these three genera. 
Macrolenes can be distinguished from Dissochaeta by a combination of morphological characters (Table 1), e.g., axillary inflorescences (versus mainly, but not always, terminal in Dissochaeta), a pair of abaxial hair cushion domatia on the base of the leaf blades (versus cushion domatia absent), longer and distinct calyx lobes, e.g. half or more of hypanthium length (versus mainly shorter and often indistinct calyx lobes, e.g. less than half of hypanthium length) and several fimbriate, filiform appendages on the connective of the alternipetalous stamens (versus only a pair of filiform, non-fimbriate appendages on the connective of the alternipetalous stamens) (Kartonegoro et al., 2018). Some species of Dissochaeta have long calyx lobes, similar to those of Macrolenes, but they are usually erect, not reflexed, and mostly fall off when fruiting (Kartonegoro et al., 2018). Based on those constant morphological differences between Macrolenes and Dissochaeta, we here keep the genera separate, following a number of earlier authors (Bakhuizen van den Brink, 1943; Maxwell, 1980a, 1984; Nayar, 1980; Kartonegoro et al., 2018).

\section{Taxonomic history}

The genus Macrolenes was established by Naudin (1851) to accomodate a Javanese woody climber described as Maieta annulata by Ventenat (1803). Naudin regarded Maieta as Neotropical only, and considered the Palaeotropical species to belong to a new genus. The name Macrolenes is based on the Greek words 'makros', large, and 'lenos', wool, referring to the long and large, fimbriate, filiform appendages on the stamens (Backer, 1936; Maxwell, 1980a). Naudin regarded the genus to be morphologically very similar to Dissochaeta based on the climbing habit and characters of the flowers, but different in having larger calyx lobes and different connective appendages (Naudin, 1851; Bakhuizen van den Brink, 1943; Maxwell, 1980a, 1984; Kartonegoro et al., 2018).

For many years, the name Marumia Blume was used for species of Macrolenes (Triana, 1872; Clarke, 1879; Cogniaux, 1890, 1891; King, 1900; Ridley, 1922) until Bakhuizen van den Brink (1943) recognised that Marumia Blume (1831) is an illegitimate name under the Code (Turland et al., 2018) because it is a later homonym of Marumia Reinw. He then reestablished Macrolenes and also pointed out that the first legitimate name in the genus was published by Naudin (1851), and not by Miquel (1855) as had been assumed, as the short generic description by Naudin is sufficient for valid publication (Bakhuizen van den Brink, 1943; Veldkamp, (1979 ['1978']). This nomenclatural problem began when Blume (1823) took up Reinwardt's genus name of Marumia when he transferred four species of Saurauia Willd. into it. At that time, however, Marumia had itself still not been validly published as it lacked a description (Turland et al., 2018 - Art. 38.1). Unfortunately, Nees von Esenbeck (1825) did not rectify this, when he reviewed Blume's work. In 1828, Reinwardt validated the name Marumia and regarded the genus as close to Vanalphenia Lesch. and Scapha Noronha, two genera now included in Saurauia in the Actinidiaceae. Blume (1831), however, considered Marumia Reinw. to be a synonym of Reinwardtia Blume ex Nees (also Actinidiaceae), which is a later homonym of Reinwardtia Dumort. Blume (1831) 
Table 1. Differences in morphological characters between Macrolenes and Dissochaeta.

\begin{tabular}{lll}
\hline Structure/Character & Macrolenes & Dissochaeta \\
\hline Base of leaf blade & $\begin{array}{l}\text { Abaxially with a pair of hair } \\
\text { cushion domatia }\end{array}$ & $\begin{array}{l}\text { Abaxially without a pair of } \\
\text { hair cushion domatia }\end{array}$ \\
$\begin{array}{l}\text { Inflorescence } \\
\text { Hypanthium }\end{array}$ & $\begin{array}{l}\text { Distinct, sometimes with } \\
\text { branched tips }\end{array}$ & $\begin{array}{l}\text { Terminal or rarely axillary } \\
\text { tips }\end{array}$ \\
Calyx lobes & $\begin{array}{l}\text { Distinct, well-developed, half } \\
\text { to as long as the length of the } \\
\text { hypanthium }\end{array}$ & $\begin{array}{l}\text { Indistinct, not well- } \\
\text { developed, less than half the } \\
\text { length of the hypanthium }\end{array}$ \\
$\begin{array}{l}\text { Connective } \\
\text { appendages }\end{array}$ & $\begin{array}{l}\text { Fimbriate filiform on the } \\
\text { alternipetalous stamens }\end{array}$ & $\begin{array}{l}\text { A filiform pair or absent on } \\
\text { the alternipetalous stamens }\end{array}$ \\
\hline
\end{tabular}

decided to adopt the generic name as a distinct genus within the Melastomataceae based on a newly described species (Marumia zeylanica Blume) and three species transferred from Melastoma L. (M. muscosa (Blume) Blume, M. nemorosa (Jack) Blume and M. stellulata (Jack) Blume). Under today's Code, Blume's use of the name for another genus is illegitimate under article 53.1 (Turland et al., 2018).

Naudin (1851) was unaware of the relationship between Macrolenes and Marumia when he accepted both names and proposed the new species Marumia echinulata Naudin, thinking that Marumia could be distinguished by pentamerous instead of tetramerous flowers. Miquel (1855) considered Macrolenes as doubtfully distinct from Dissochaeta, an opinion shared by Bentham \& Hooker (1867) and other botanists (Triana, 1872; Clarke, 1879; Cogniaux, 1890, 1891; Krasser, 1893; King, 1900; Ridley, 1922)

In this revision, seventeen species are recognised. Thirteen were already known, one new combination is made and three species are described as new. All species are endemic to the Malesian region, especially to the western part including the southern part of the Peninsular Thailand. Macrolenes nemorosa (Jack) Bakh.f., M. pachygyna (Korth.) M.P.Nayar and M. stellulata (Jack) Bakh.f. are widespread but absent from Java. This revision is solely based on morphological features from herbarium specimens.

\section{Materials and methods}

Material for the study, including online specimen images (https://plants.jstor.org/ collection), was provided by the following herbaria: AAU, ANDA, BK, BM, BO, BR, E, G, K, KEP, L, M, P, PE, PNH, SING, and U (herbarium acronyms follow Thiers, 
2018). Measurements were made on representative herbarium specimens. Surface indumentum of the leaves, flowers and fruits were examined from dried specimens, flower and fruit colour in vivo were obtained from data on the labels; the latter were also the source for the ecological notes, vernacular names and local uses of a species.

Species delimitation in this revision is based mostly on the shape, size and indumentum of the calyx tube or the hypanthium. Some species have different types of hairs on branchlets, leaves and the hypanthium, e.g., Macrolenes dimorpha (Craib) J.F.Maxwell, M. hirsuta (Cogn.) J.F.Maxwell, and M. stellulata. Unlike Dissochaeta, the stamens and the depth of the extra-ovarial chambers are uniform among the species and, therefore, not useful as specific characters.

\section{General morphology}

\section{Habit}

The species of Macrolenes are, like those of Dissochaeta, woody climbers with a scrambling growth habit. Usually the plants climb in small trees or shrubs and very rarely climb into high trees. In some species, adventitious roots are common, which lignify and soon desiccate and become a hook-shaped structure (Clausing \& Renner, 2001). The branchlets may be terete and glabrous, or covered by a stellatefurfuraceous, tomentose to slightly setose indumentum. The nodes are usually swollen with a distinct interpetiolar ridge, sometimes with only an annular ridge or sometimes a crest-like appearance (e.g., Macrolenes annulata (Vent.) Naudin and M. stellulata).

\section{Leaves}

The phyllotaxis of all species of Macrolenes is opposite and, as in Dissochaeta, the leaves are arranged in two rows (Kartonegoro et al., 2018). The leaves of several species are coriaceous when dry. The shape of the blades varies from broadly ovate to elliptic to oblong. The apex of the blades is usually acuminate, the margin entire and the base subcordate to cordate. An acrodromal venation is common in Macrolenes with one pair of lateral veins arising from the base, just beside the midrib, and an additional pair of intramarginal veins also present. In general, the leaf blades have numerous secondary veins and the finer veins form a reticulate pattern; the midrib is sunken above and raised below (Maxwell, 1984). The upper surface is usually glabrous with a glossy green colour, while the lower part varies from glabrous, to puberulous to furfuraceous to tomentose with a brownish colour. On the lower surface of the leaf blade a pair of hair cushions (domatia) at the base is common (Fig. 1A), which are patches of simple or stellate hairs that are persistent when dry (Maxwell, 1984). This domatia feature is found in all species in the genus and can be used to distinguish it from Dissochaeta. This feature resembles a pair of glandular patches at the base of the leaf blades in some species of Dissochaeta, the function of which is also still unknown (Maxwell, 1984; Kartonegoro et al., 2018). Similar to Dissochaeta, the petiole in Macrolenes is terete or cylindrical with a dorsal groove that may give the petiole a flat appearance. The indumentum of the petiole is commonly similar to that of the branchlets (Kartonegoro et al., 2018). 


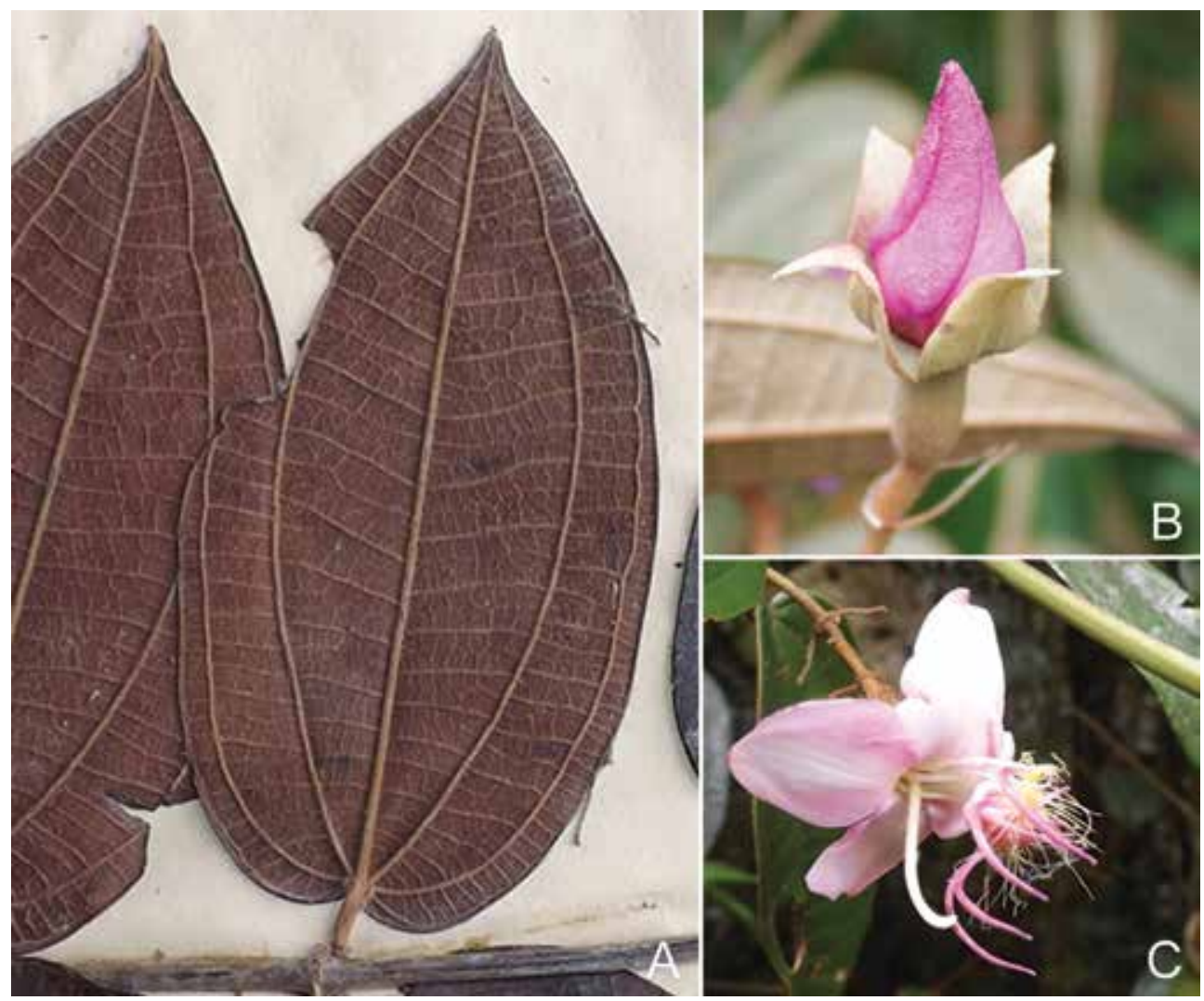

Fig. 1. Morphology of Macrolenes. A. Leaves with a pair of hair cushions at the base in Macrolenes stellulata. B. Hypanthium with well-developed and reflexed calyx lobes in Macrolenes nemorosa. C. Flower with fimbriate appendages on the connectives of the alternipetalous stamens in Macrolenes muscosa. A from Forbes 3008 (K); B from Kartonegoro 1070 (BO); C from Kartoneogoro 1108 (BO). (Photos: A. Kartonegoro)

\section{Inflorescences}

The inflorescences of Macrolenes are axillary and consist of few-flowered cymes with 1-15 flowers. The main axes of the cymes are usually terete, angular or 4-angled with distinctly swollen nodes. The indumentum is similar to that of the branchlets. Dissochaeta can have high order ramifications, up to 5 orders (Maxwell, 1984; Kartonegoro et al., 2018), but the ramifications in Macrolenes usually have 1-3 orders of opposite branches that end with 3-flowered cymules in the last ramification. Sometimes the inflorescence only consists of a single flower in the leaf axil. The central flower of the terminating cymules has one less order of ramification and has a pedicel longer than that of the two lateral ones (Maxwell, 1984). The central flower will mature and bloom first and is followed later by the two lateral ones simultaneously. Bracts and bracteoles are paired and vary from linear to ovate, but are usually caducous. The bracts are present on the nodes of each ramification, while the bracteoles are found on each pedicel, where they subtend a single flower. 


\section{Hypanthium and calyx}

The shape of the hypanthium varies from tubular to campanulate to suburceolate. The indumentum of the hypanthium is an important character for distinguishing the species in Macrolenes. There is a range from glabrous to tomentose to floccose or setose with or without dense bristle hairs, sometimes the surfaces are tuberculate. The bristle hairs vary from simple to branched, with or without a barbed tip. Several species, such as Macrolenes hirsuta, M. pachygyna and M. stellulata, are found with branched or barbed-tip bristle hairs. The size of the hypanthium can be used to distinguish Macrolenes from Dissochaeta as Macrolenes always has a larger hypanthium than Dissochaeta. Another important character is in the calyx lobes, which are usually welldeveloped, distinctly triangular or rounded and mostly have a length similar to the hypanthium (Fig. 1B).

\section{Petals}

The petals are thin, conspicuous, symmetric, colourful and have a visible venation. They are usually obovate or suborbicular with an obtuse apex and clawed base. The colour of the petals varies from white to pink to bright purple, but cannot be used to distinguish the species. The petals are not reflexed when mature.

\section{Stamens}

Unlike the similar genera Creochiton Blume and Dissochaeta, the characters of the stamens in Macrolenes are not considered to be of great taxonomic importance to distinguish the species. This is because in all species the stamens are uniform in shape and number (Mawell, 1984; Kartonegoro \& Veldkamp, 2010, 2013; Kartonegoro et al., 2018). All species have 8 heterantherous, fertile stamens in usually two, dimorphic staminal whorls, an outer, alternipetalous one, and an inner, oppositipetalous one (Maxwell, 1980a; Nayar, 1980). The alternipetalous stamens are known as pollinating stamens and the oppositipetalous ones are the feeding stamens (Kadereit, 2006; Kartonegoro \& Veldkamp, 2010). Staminodes are unknown in Macrolenes as all stamens are well-developed in the flowers.

All stamens have filaments that are equal in shape, they are flattened and curved sideways when mature. The length and direction of the filaments are uniform and they curve in the opposite direction to that of the style (Fig. 1C). The stamens are inserted within the hypanthium in the extra-ovarial chambers. Before anthesis, the filaments face towards the outside while the anthers face towards the inside, similar to Dissochaeta (Maxwell, 1984; Kartonegoro et al., 2018). The filaments that alternate with the petals are straight and the point of attachment with the anthers is clearly on the top, while those opposite to the petals are sharply bent and incurved before reaching the point of attachment with the anthers and the attachment to the anther is called the stipopodium (Veldkamp et al. (1979 ['1978’]); Maxwell, 1984; Kartonegoro et al., 2018). Both types of anthers are basifixed.

The anthers are elongated and glabrous and open distally with a single pore. In mature flowers the anthers reverse their orientation from being folded next to the filaments to bending upwards away from the filaments (Maxwell, 1984; Kartonegoro et al. 2018). 
When the flowers are mature, the anthers of the alternipetalous stamens are curved in a sickle-shape, while the anthers of the oppositipetlaous stamens are hooked or ' $\mathrm{S}$ '-shaped. The oppositipetalous anthers are usually thicker and shorter than the alternipetalous ones. The connective of the alternipetalous anthers is usually sterile in the basal part and lacks a theca. This sterile zone is known as the pedoconnective and is found in some taxa of the Melastomataceae and varies in size correlating with the size of the stamens (Kadereit, 2006; Wong, 2016; Kartonegoro et al., 2018). A pedoconnective in the oppositipetalous stamens is uncommon or not developed. The base of the pedoconnective usually has basal appendages or a crest that is prolonged into several fimbriate or capillary appendages (Fig. 1C). The connective in the oppositipetalous stamens extends from the lower part of the thecae and is adaxially bifid, or has ligular, erose or spuriform appendages and laterally or basally a pair of filiform appendages.

\section{Ovary}

The relative length of the ovaries varies from about $1 / 3$ the length of the hypanthium to nearly as long as the hypanthium. The ovary has a villous indumentum. The ovary tip is usually rounded or conical. The placentation of the ovules in Macrolenes is similar to the other genera in the tribe Dissochaeteae (except for a few Creochiton species), axillary with one placenta in each of the four locules; the placenta is attached to the middle of the central column (Maxwell, 1984). The style in bud is straight and at maturity slightly curved, especially at the tip. The direction of curve of the style is usually opposite to that of the curve of the filaments. The stigma of all species is minute and capitate to inconspicuous. There are 8 extra-ovarial chambers, which mostly extend from the top of the ovary to the middle or base. The anthers included to these chambers when immature and still in bud.

\section{Fruit}

Like in all other genera in tribe Dissochaeteae, the fruits of Macrolenes are berries, ovoid to urceolate and colourful when mature, with four persistent remnants of the calyx lobes. The indumentum of the fruits resembles that of the hypanthium and the colour is green at first, later ripening to dark blue to purple. Clausing et al. (2000) suggest that, unlike in Dissochaeta, in Macrolenes the hard berries are characterised by a persistent endocarp in which the ground tissues of the mesocarp and hypanthium are not fused and in both the ground tissue contains a dense ring of sclereids. Based on our observations, we cannot confirm this as a constant differentiating character. The seeds are cuneate, flat-topped and smooth.

\section{Distribution and ecology}

Macrolenes is mainly distributed in West Malesia: Malay Peninsula, Sumatra, Java and Borneo. Some species are also found in the southern part of Peninsular Thailand. The genus has never been recorded in Cambodia, Laos or Vietnam or further to the 
west. It is also absent in eastern Malesia (Philippines, Sulawesi, Lesser Sunda Islands, Moluccas and New Guinea).

Ecologically, Macrolenes resembles Dissochaeta, as the species are woody climbers in tropical evergreen and perpetually wet forest types with little or no seasonal variation in temperature and rainfall (Maxwell, 1984; Clausing \& Renner, 2001; Kartonegoro et al., 2018). The genus is predominantly found in secondary vegetation or in more open places within primary vegetation, such as tree fall gaps, river margins and roadsides. The plants climb several metres high and produce their flowering and fruiting branches over the tops of trees and larger shrubs. These woody climbers apparently only flower when the branchlets are in an exposed location. Branchlets that are not exposed to direct sunlight, regardless of their height in the forest or maturity, do not produce flowers (Maxwell, 1984).

Most species are confined to lowland and hilly areas up to $1500 \mathrm{~m}$ elevation and occur in a variety of lowland forest types, such as mixed dipterocarp forest, heath forest or swampy forest. Some taxa are found in montane forest, e.g. Macrolenes glabrata M.P.Nayar, M. muscosa (Blume) Bakh.f. and M. neglecta M.P.Nayar. There is no specific flowering and fruiting season and the plants flower and fruit throughout the year.

\section{Taxonomic treatment}

Macrolenes Naudin, Ann. Sci. Nat., Bot. sér. 3, 15: 311 (1851); Miquel, Fl. Ned. Ind. 1(1): 557 (1855); Bakhuizen van den Brink, Contr. Melastom. 203 (1943); Bakhuizen van den Brink in Backer \& Bakhuizen van den Brink, Fl. Java 1: 363 (1964); Veldkamp, Blumea 24: 445 (1979 ['1978’]); Nayar, J. Jap. Bot. 55: 45 (1980); Maxwell, Gard. Bull. Singapore 33: 321 (1980). - TYPE: Macrolenes annulata (Vent.) Naudin.

Marumia Blume, Flora 14: 503 (1831), nom. illeg., non Reinw. (1828); Don, Gen. Hist. 2: 731 (1832); Blume, Rumphia 1: 17 (1835); Endlicher, Gen. P1. 1220 (1840); Korthals in Temminck, Verh. Nat. Gesch. Ned. Bezitt., Bot. 240 (1844); Blume, Mus. Bot. 1(3): 33 (1849); Naudin, Ann. Sci. Nat. Bot. sér. 3, 15: 279 (1851); Miquel, Fl. Ned. Ind. 1(1): 532 (1855); Bentham \& Hooker, Gen. P1. 1: 757 (1867); Triana, Trans. Linn. Soc. London 28(1): 82 (1872); Clarke in Hooker, Fl. Brit. India 2: 541 (1879); Baillon, Hist. P1. 7: 52 (1877); Cogniaux in Boerlage, Handl. F1. Ned. Ind. 2: 517, 532 (1890); Cogniaux in de Candolle \& de Candolle, Monogr. Phan. 7: 548 (1891); Krasser in Engler \& Prantl, Nat. Pflanzenfam. 3, 7: 180 (1893); King, J. Asiat. Soc. Bengal, Pt. 2, Nat. Hist. 69(1): 47 (1900); Koorders, Exkurs.-Fl. Java 2: 694 (1912); Ridley, F1. Malay Penins. 1: 794 (1922); Merrill, Univ. Calif. Publ. Bot. 25: 223 (1929); Craib, F1. Siam. Enum. 10: 696 (1931); Furtado, Gard. Bull. Singapore 20: 114 (1963). TYPE: Marumia muscosa (Blume) Blume (=Macrolenes muscosa (Blume) Bakh.f.), lectotype designated here.

Maieta auct. non Aubl.: Ventenat, Choix P1. 32 (1803) (p.p., excl. type). 
Melastoma auct. non Burm. ex L.: Jack, Trans. Linn. Soc. London 14: 3 (1823); Blume, Bijdr. Fl. Ned. Ind. 17: 1067 (1826); de Candolle., Prodr. 3: 144 (1828) (all p.p., excl. type).

Huberia auct. non DC.: de Candolle, Prodr. 3: 167 (1828); Don, Gen. Hist. 2: 779 (1832) (all p.p., excl. type).

Dissochaeta auct. non Blume: Clausing in Renner et al., Fl. Thailand 7(3): 418 (2001) (p.p., excl. type).

Woody climbers, scrambling; bark tan to light brown, finely fissured. Branchlets terete; glabrescent to tomentose or floccose with minute stellate or simple glandular or eglandular bristle hairs; adventitious roots common; nodes swollen, with an interpetiolar annular line, ridge or crest. Stipules not present. Leaves opposite, simple; petioles terete, with a dorsal groove, glabrescent to tomentose; blades ovate to oblong, membranous to subcoriaceous, base shallowly cordate, margins entire, apex acute to acuminate, midvein with 1 pair of lateral veins and 1 pair of intramarginal veins, secondary venation reticulate; adaxially glabrous, greenish glossy, abaxially glabrous to densely brown tomentose, basally with a pair of hair cushion domatia of simple or stellate hairs. Inflorescences axillary, cymose, with 1-15 flowers, often paniculate thyrses with 1-3 ramifications, generally ending in 3-flowered cymules; main axis terete or quadrangular, indument similar to that of the branchlets; bracts and bracteoles distinct or minute, linear to ovate or suborbicular, densely stellate-tomentose, often ciliate or serrate, rarely inconspicuous and early caducous; pedicels longer in the central flower, shorter in the lateral ones, furfuraceous to tomentose, sometimes with bristle hairs. Flowers 4-merous. Hypanthium campanulate, urceolate or tubular, glabrous to densely tomentose or rarely floccose with minute brown stellate hairs, with or without simple or branched- or barbed-tip bristle hairs, usually covered by minute brown stellate hairs, sometimes tuberculate; calyx lobes distinct, triangular, ovate or lanceolate, generally at least half as long as the hypanthium, glabrous or densely tomentose, with or without bristle hairs, margin often ciliate, apex acute or rounded. Petals in bud conical, tip acute, blades half overlapping along one side, glabrous or tomentose; mature petals ovate, obovate or spathulate, symmetric, clawed, base thin, apex obtuse, glabrous or tomentose along the margin of the half overlapping dorsal margin, white, pink or violet. Stamens 8, heterantherous, dimorphic, in two rows, 4 alternipetalous and 4 oppositipetalous, all fertile, smooth, thecae with terminal pore; filaments flattened, straight in bud, curved sideways when mature, glabrous, white or yellowish; the alternipetalous ones longer and thinner than the oppositipetalous ones, when mature sickle-shaped, at base forming a pedoconnective, connective basal crest membranous, annular, prolonged into several fimbriate, filiform appendages, laterally sometimes an additional pair of filiform appendages, longer than the fimbriate appendages; the oppositipetalous stamens hooked or S-shaped when mature, connective ridge with erose, bifid or keeled appendages, basally extended with a pair of filiform appendages. Ovary half to $3 / 4$ as long as the hypanthium, 4-locular, apex generally 
villous and bristly; style curved at the tip when mature, curved in the opposite direction to the curve of the filaments; stigma minute, capitate; ovary concrescent with the hypanthium, with 8 longitudinal septa forming extra-ovarial chambers for the anthers, reaching to (nearly) the base of the ovary. Fruits baccate, ovoid to urceolate, glabrous to floccose, hairs similar to those on hypanthium; with four prominent reflexed calyx remnants. Seeds numerous, cuneate, smooth, flat-topped.

Distribution. Seventeen species found in the southern part of Peninsular Thailand, the Malay Peninsula, Sumatra, Java and Borneo (Fig. 2).

Habitat \& ecology. Predominantly found in secondary vegetation or more open places within primary vegetation, such as tree fall gaps, river margins and roadsides (Maxwell, 1984; Kadereit, 2006) in several types of everwet forest, of which the preferred habitats are evergreen forest, mixed dipterocarp forest, and submontane forest. They climb several metres high and produce their flowering and fruiting branches only in open space over the tops of small trees and larger shrubs or bushes.

Notes. Even though Macrolenes is similar in habit, flower merosity, stamen type and habitat preference to Dissochaeta, the genus can easily be distinguished by its combination of axillary inflorescences, leaf blades with an abaxial pair of hair cushion domatia at the base, large flowers, distinct calyx lobes, fimbriate filiform appendages on the connective of the alternipetalous stamens and a distinct bristle indumentum on the hypanthium. The number and type of stamens and their connective appendages are important for species recognition in Dissochaeta, but these characters are uniform in Macrolenes.

\section{Key to Macrolenes species}

1a. Branchlets covered with minute stellate hairs and dense simple bristle hairs ..... 2

1b. Branchlets glabrescent, stellate-furfuraceous or -tomentose, floccose, with or without scattered bristle hairs

2a. Branchlets covered with c. $0.75 \mathrm{~mm}$ long thick, brown and prominent bristle hairs [Borneo] 8. M. hirsuta

2b. Branchlets covered with 2-3 mm long simple slender, dark maroon bristle hairs [Malay Peninsula, Sumatra] 5. M. echinulata

3a. Petioles with scattered slender black bristle hairs, 3-5 mm long [Borneo] 2. M. bipulvinata

3b. Petioles without any bristle hairs 4

4a. Hypanthium and fruits without bristle hairs [Southern Thailand, Peninsular Malaysia, Sumatra \& Borneo] 10. M. nemorosa 
4b. Hypanthium and fruits (unknown for M. neglecta) covered with scattered or dense bristle hairs/tubercles ............................................................................. 5

5a. Bristle hairs on hypanthium glabrous, not covered with minute stellate hairs .... 6

5b. Bristle hairs/tubercles on hypanthium covered with minute stellate hairs ......... 8

6a. Leaf blades abaxially sparsely stellate-puberulous to glabrous; calyx lobes lanceolate [Sumatra \& Java] 1. M. annulata

6b. Leaf blades abaxially stellate-tomentose to pubescent; calyx lobes ovate or triangular 7

7a. Bracteoles ovate, margin serrate, glabrous, persistent [Sumatra]

10. M. neglecta

7b. Bracteoles subulate, margin entire, pubescent, caducous [Thailand] 6. M. esetosa

8a. Bristle hairs on hypanthium strongly and prominently branched or barbed at tip ..

8b. Bristle hairs/tubercles on hypanthium simple, not distinctly branched or barbed at tip, but capitate to some slightly branched at most

9a. Nodes with annular crest-like interpetiolar ridge; leaf blades abaxially stellatepuberulous; bracts ovate, 10-12 $\mathrm{mm}$ long, margin ciliate, persistent; hypanthium tubular, greyish when dry [Peninsular Malaysia, Sumatra, Borneo] .. 14. M. stellulata

9b. Nodes with simple interpetiolar ridge; leaf blades abaxially stellatetomentose; bracts linear or lanceolate, 5-8 mm long, margin not ciliate, caducous; hypanthium campanulate to suburceolate, brownish when dry 10

10a. Pedicels stellate-furfuraceous and without bristle hairs; hypanthium with branched- or barbed-tip bristle hairs which are covered with minute stellate hairs from apex to base [Sumatra, Borneo] 12. M. pachygyna

10b. Pedicels stellate-furfuraceous and covered with bristle hairs; bristle hairs of hypanthium with minute stellate hairs at apex only, base glabrous [Borneo] .... 17. M. veldkampii

11a. Leaf blades abaxially glabrous; petioles $15-25 \mathrm{~mm}$ long; hypanthium with 5-6 $\mathrm{mm}$ long bristle hairs with simple unbranched-tip or weakly branched at tip [Peninsular Malaysia] .............................................................. 7. . .. glabrata

11b. Leaf blade abaxially stellate-furfuraceous, tomentose or floccose; petioles 5-12 mm long; hypanthium with $0.5-5 \mathrm{~mm}$ long simple bristle hairs/tubercles with capitate or non-branched tip 
12a. Margin of calyx lobes with dense bristle hairs, ciliate ...................................... 13

12b. Margin of calyx lobes without dense bristle hairs, not ciliate ........................... 14

13a. Leaf blades subcoriaceous; petioles c. $10 \mathrm{~mm}$ long; bristles on hypanthium fully covered by minute stellate hairs; calyx lobes triangular, 5-6 $52-3 \mathrm{~mm}$; petals in bud brown tomentose or pubescent [Sumatra \& Java] 9. M. muscosa

13b. Leaf blades membranous; petioles 6-8 mm long; bristles on hypanthium covered by minute stellate hairs only at tip; calyx lobes slightly triangular, 9-11 $\times 4-6$ $\mathrm{mm}$; petals in bud glabrous [Sumatra] 15. M. subulata

14a. Hypanthium campanulate-cyathiform; calyx lobes triangular, $3.5-5 \mathrm{~mm}$ long; petals in bud stellate-furfuraceous; ovary $3 / 4$ as long as hypanthium 15

14b. Hypanthium campanulate or campanulate-tubular; calyx lobes triangular, 5-15 $\mathrm{mm}$ long; petals in bud glabrous (unknown for M. rufolanata); ovary $2 / 3$ as long as hypanthium

15a. Branchlet, petiole and inflorescence axes floccose; bracts and bracteoles oblong or lanceolate, persistent; hypanthium floccose and with scattered 1-2 mm long capitate bristle hairs [Borneo] 3. M. bruneiensis

15b. Branchlet, petiole and inflorescence axes tomentose; bracts and bracteoles minute, less than $1 \mathrm{~mm}$ long, caducous; hypanthium tomentose and with c. 0.5 $\mathrm{mm}$ long tubercles [Sumatra] 16. M. tuberculata

16a. Nodes with interpetiolar crest-like ridge; leaf blades membranous; bracteoles elliptic or elliptic-oblong, 10-12 mm long, persistent; hypanthium with up to $4 \mathrm{~mm}$ long bristle hairs; calyx lobes $9-15 \times 6-8 \mathrm{~mm}$ [Thailand, Peninsular Malaysia, Sumatra] 4. M. dimorpha

16b. Nodes with interpetiolar simple ridge; leaf blades subcoriaceous; bracteoles ovate, $2-3 \mathrm{~mm}$ long, caducous; hypanthium with up to $1.5 \mathrm{~mm}$ long bristle hairs; calyx lobes $5-7 \times$ c. $3 \mathrm{~mm}$ [Peninsular Malaysia] 13. M. rufolanata

1. Macrolenes annulata (Vent.) Naudin, Ann. Sci. Nat., Bot. sér. 3, 15: 311 (1851); Miquel, Fl. Ned. Ind. 1(1): 558 (1855); Bakhuizen van den Brink, Contr. Melastom. 213 (1943); Bakhuizen van den Brink in Backer \& Bakhuizen van den Brink, Fl. Java 1: 363 (1964). - Maieta annulata Vent., Choix Pl. 32 (1803). - Huberia annulata (Vent.) DC., Prodr. 3: 167 (1828). - Marumia annulata (Vent.) Triana, Trans. Linn. Soc. London 28(1): 82 (1872); Cogniaux in Boerlage, Handl. Fl. Ned. Ind. 2: 532 (1890); Cogniaux in de Candolle \& de Candolle, Monogr. Phan. 7: 550 (1891); Baker, J. Bot. 62, Suppl.: 39 (1924). - TYPE: Indonesia, Java, de Lahaye s.n. "2860" (holotype G-DC [G00341515, image seen]). (Fig. 3)

Marumia zeylanica Blume, Flora 14: 505 (1831); Blume, Rumphia 1: 19, t. 5 (1835); Naudin, Ann. Sci. Nat., Bot. sér. 3, 15: 283 (1851); Miquel, Fl. Ned. Ind. 1(1): 536 


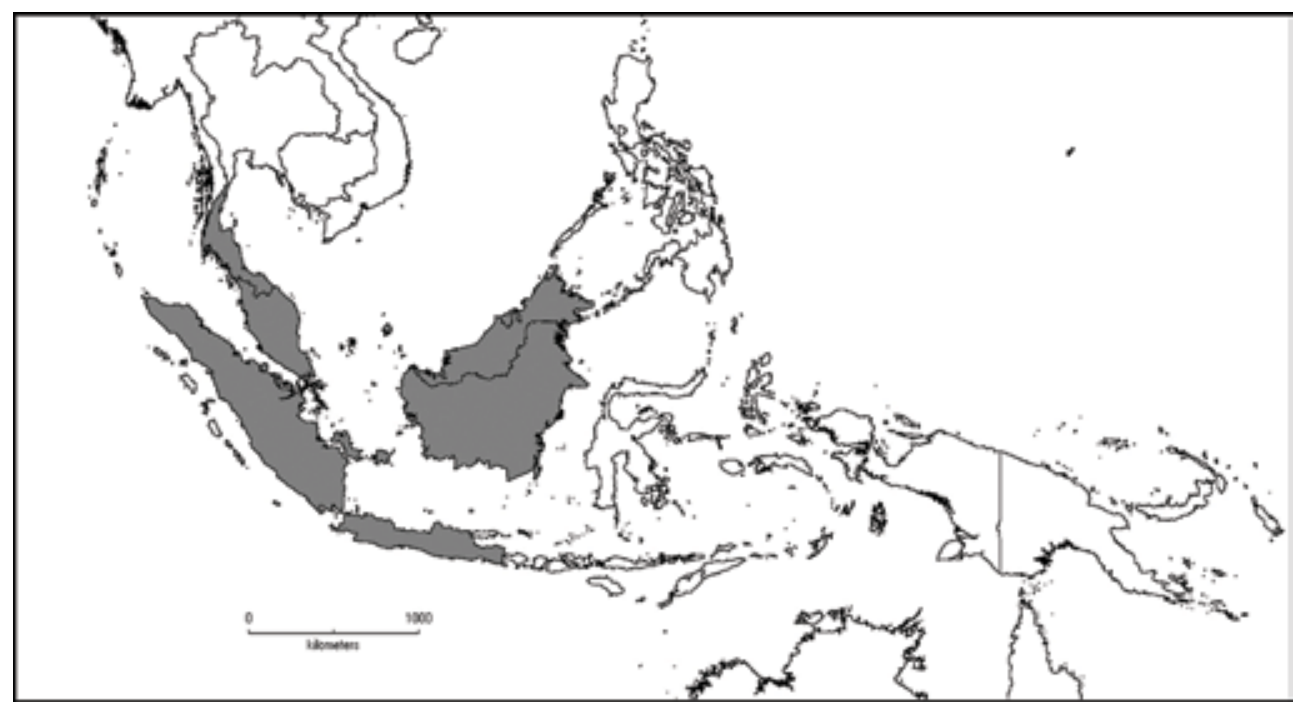

Fig. 2. Distribution of Macrolenes (grey).

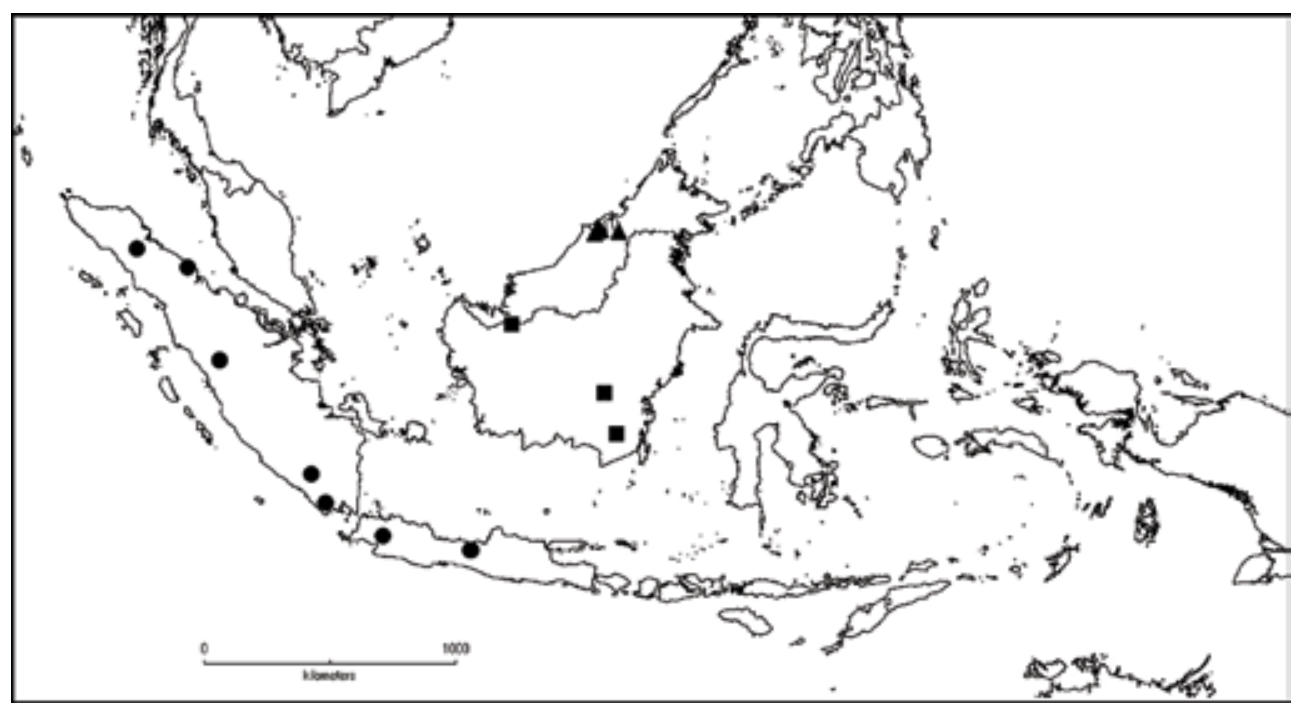

Fig. 3. Distribution of M. annulata (Vent.) Naudin (•); M. bipulvinata (Korth.) Bakh.f. (๘); and M. bruneiensis Karton. ( $\mathbf{\Delta})$.

(1855); Triana, Trans. Linn. Soc. London 28(1): 82 (1872). - Macrolenes zeylanica (Blume) Bakh.f., Contr. Melastom. 212 (1943); Bakhuizen van den Brink in Backer \& Bakhuizen van den Brink, Fl. Java 1: 363 (1964). - TYPE: Zeylania?, Leg. Ign. (Herb. Van Royen) (holotype L [L0537198]). 
Marumia horsfieldii Miq., Fl. Ned. Ind. 1(1): 536 (1855); Triana, Trans. Linn. Soc. London 28(1): 82 (1872); Cogniaux in Boerlage, Handl. Fl. Ned. Ind. 2: 532 (1890); Cogniaux in de Candolle \& de Candolle, Monogr. Phan. 7: 550 (1891); Koorders, Exkurs.-Fl. Java 2: 694 (1912). - TYPE: Indonesia, Java, G. Prahoe, T. Horsfield 19 (lectotype L [L0537199], designated by Bakhuizen van den Brink in Contr. Melastom. 213 (1943)); isolectotype K [K000867116]).

Climbing up to $30 \mathrm{~m}$ high. Branchlets terete, $3-5 \mathrm{~mm}$ in diameter, glabrous or glabrescent; nodes swollen, with a 1-3 mm wide annular crest-like interpetiolar ridge; internodes 3.8-5 cm long. Leaves: petioles terete, $5-8 \mathrm{~mm}$ long, stellate-furfuraceous; blades elliptic to oblong, $8-14 \times 2.5-5 \mathrm{~cm}$, membranous, base shallowly cordate, margin entire, apex acuminate, acumen $1-1.5 \mathrm{~cm}$ long, adaxially glabrous, dark green, abaxially sparsely stellate-puberulous to glabrous. Inflorescences $5-13 \mathrm{~cm}$ long, 1-3-flowered cymes to 10-20-flowered panicles; main axis angular, stellatefurfuraceous; primary axis $2-4 \mathrm{~cm}$ long with 1 node or in panicles up to $5 \mathrm{~cm}$ long with 2 nodes, secondary axis when developed $1-1.3 \mathrm{~cm}$ long or when in long panicles up to $2 \mathrm{~cm}$ long with 1 or 2 nodes, tertiary axis in panicles up to $1.5 \mathrm{~cm}$ long with 1 node; bracts linear, 5-6 mm long, stellate-furfuraceous, margin entire, caducous; bracteoles subulate to linear, c. $5 \mathrm{~mm}$ long, stellate-furfuraceous; pedicels stellate-furfuraceous and with scattered simple bristle hairs, 4-5 $\mathrm{mm}$ long in central flowers, $1-3 \mathrm{~mm}$ long in lateral flowers. Hypanthium campanulate-tubular, 7-8 × 3-4 mm, covered with stellate-furfuraceous hairs and $1.5-2 \mathrm{~mm}$ long simple glabrous bristle hairs; calyx lobes lanceolate with truncate base, $4-5 \times$ c. $2 \mathrm{~mm}$, sparsely stellate-furfuraceous, apex obtuse, margin entire, with short bristle hairs. Petals in bud conical, $8-10 \mathrm{~mm}$ long, glabrous; mature petals obovate, 10-14 × 9-10 mm, base clawed, apex obtuse, glabrous, pink. Stamens alternipetalous stamens with 10-11 mm long filaments, anther slender, sickle-shaped, thecae $15-17 \mathrm{~mm}$ long, pink to purplish, pedoconnective c. $5 \mathrm{~mm}$ long, connective basal crest small, annular, prolonged into several fimbriate, filiform appendages, 4-5 $\mathrm{mm}$ long, lateraly with paired, filiform appendages, 5-6 $\mathrm{mm}$ long; oppositipetalous stamens with $8-9 \mathrm{~mm}$ long filaments, anthers S-shaped, thick, thecae 14-15 mm long, connective with a pair of ridges or keels, c. $1 \mathrm{~mm}$ long, basally with paired, filiform lateral appendages, 4-6 $\mathrm{mm}$ long. Ovary half as long as hypanthium, apex villous; style 18-21 mm long, curved at apex, glabrous; stigma minute; extra-ovarial chambers extending from middle to base of the ovary. Fruits urceolate, 10-12 × 7-8 mm, sparsely covered with stellate-furfuraceous hairs and simple glabrous bristle hairs; calyx lobes persistent, reflexed. Seeds c. 0.5 mm long.

Distribution. Sumatra and Java.

Habitat \& ecology. Edge of primary lowland forest, disturbed forest or montane forest; at 350-1500 m elevation. 
Additional specimens examined. INDONESIA: Aceh: Mount Leuser Nat. Park., Gunung Bandahara, 800 m, 20 Mar 1975, de Wilde \& de Wilde-Duyfjes 15597 (K, L). Lampung: Kota Agung, 350 m, 19 May 1968, Jacobs 8499 (K, L). North Sumatra: Serdang, Penampang road, 10 Jul 1929, Coert 734 (L). South Sumatra: Forbes 1832 (BM); Forbes 2852 (BM, K, L). West Sumatra: Lima Puluh Kota, Atas Halaban, Bukit Ngalau Kasemeh, 580 m, 26 May 1994, Hendra 9 (ANDA); Lima Puluh Kota, Atas Halaban, Bukit Ngalau Kasemeh, 580 m, 26 May 1994, Nofril 69 (ANDA). Java: Horsfield s.n. (L).

Notes. Macrolenes annulata can easily be recognised by its simple, 1.5-2 mm long bristle hairs on the hypanthium, but the branchlets, leaves and petioles are rather glabrous to glabrescent and lack bristle hairs. The species resembles Macrolenes echinulata, which also has dark maroon bristles on all parts except the leaves. Macrolenes neglecta is also similar due to its bristle hairs on the hypanthium, but differs in having subcoriaceous leaf blades that are tomentose underneath.

Macrolenes annulata does not occur in Sri Lanka or South Coast India, therefore it is doubtful that the holotype of Marumia zeylanica with the annotation "herb. Van Royen", Zeylania, was really collected on Sri Lanka (formerly Ceylon) or South India. It more likely came from Sumatra or Java where all other collections came from. Perhaps the specimen was transferred via Sri Lanka/S India to the Netherlands as the Dutch had trading posts in those areas.

2. Macrolenes bipulvinata (Korth.) Bakh.f., Contr. Melastom. 218 (1943). - Dissochaeta bipulvinata Korth. in Temminck, Verh. Nat. Gesch. Ned. Bezitt., Bot. 239 (1844); Blume, Mus. Bot. 1(3): 36 (1849); Naudin, Ann. Sci. Nat., Bot. sér. 3, 15 : 79 (1851); Miquel, Fl. Ned. Ind. 1(1): 530 (1855). - Marumia bipulvinata (Korth.) Triana, Trans. Linn. Soc. London 28 (1): 82 (1872); Cogniaux in Boerlage, Handl. Fl. Ned. Ind. 2: 532 (1890); Cogniaux in de Candolle \& de Candolle, Monogr. Phan. 7: 553 (1891). - TYPE: Indonesia, Borneo, SE Borneo, G. Rantau, P.W. Korthals s.n. (lectotype L [L06346514], first step designated by Bakhuizen van den Brink in Contr. Melastom. 218 (1943); second step designated here; isolectotypes BR [BR519595, image seen], P [P05283656, P05283657, images seen]). (Fig. 3)

Climbing up to $2 \mathrm{~m}$ high. Branchlets terete, 3-6 $\mathrm{mm}$ in diameter, densely covered with brown stellate-furfuraceous to tomentose hairs and scattered, 3-5 mm long, simple, black bristle hairs; nodes swollen, with an annular crest on the interpetiolar ridges, densely brown tomentose; internodes 5-12 cm long. Leaves petioles terete, c. $5 \mathrm{~mm}$ long, densely stellate-furfuraceous and with scattered, simple, black bristle hairs of 3-5 mm long; blades ovate-elliptic, 8.5-14 × 3-6.5 cm, subcoriaceous, base shallowly cordate, margin entire, apex acuminate, acumen c. $5 \mathrm{~mm}$ long, adaxially glabrous or with scattered stellate hairs, abaxially brown tomentose. Inflorescences, flowers and fruits unknown.

Distribution. Borneo (Kalimantan). 
Habitat \& ecology. Lowland dipterocarp forest in open areas at c. $150 \mathrm{~m}$ elevation.

Additional specimens examined. INDONESIA: South Kalimantan: Dusun, Korthals s.n. (L). West Kalimantan: Sintang, Ketungau Tengah, Nanga Kelapan, 150 m, 15 Apr 2014, Kartonegoro \& Pratama 781 (BO).

Notes. This species was described by Korthals in 1844 (Korthals, 1842-1844) based on only two collections with only vegetative branches and lacking any generative parts. The presence of a pair of hair cushions on the base of the leaves is typical for Macrolenes, and not Dissochaeta. The appearance of its branchlets and leaves resembles Macrolenes pachygyna, but the latter usually lacks bristle hairs. The bristle hairs in Macrolenes hirsuta are more prominent, thicker and erect and different from those of M. bipulvinata. Macrolenes echinulata has denser bristle hairs on branchlets and petioles, which are rather scattered in M. bipulvinata.

\section{Macrolenes bruneiensis Karton., sp. nov.}

Macrolenes stellulata auct. non Bakh.f.: Bygrave \& Davis, Checkl. Fl. Pl. Gymnosperms Brunei Darussalam 187 (1996). (p.p. excl. type.)

Climber with dense floccose indumentum and also cyathiform hypanthium with rather short triangular calyx lobes, c. 5 by $3.5 \mathrm{~mm}$. Shape and size of the hypanthium closely resembles Macrolenes tuberculata Karton. but differs in indumentum type as $M$. tuberculata has a tuberculate indumentum. - TYPE: Brunei Darussalam, Belait District, Merangking-Buau Road, 10 August 1991, Nangkat 246 (holotype BO; isotypes BRUN n.v., K, L, SING n.v.). (Fig. 3-4)

Climbing up to $3 \mathrm{~m}$ high. Branchlets terete, 3-4 $\mathrm{mm}$ in diameter, floccose, densely covered with brown stellate-tomentose hairs; nodes swollen, with interpetiolar ridges, densely covered with brown stellate-tomentose hairs; internodes $4-4.5 \mathrm{~cm}$ long. Leaves : petioles terete, c. $5 \mathrm{~mm}$ long, floccose, with densely brown stellate-tomentose hairs; blades ovate to ovate-elliptic, $8-10 \times 3-4.5 \mathrm{~cm}$, subcoriaceous, base subcordate, margin entire, apex acuminate, acumen $0.7-1 \mathrm{~cm}$ long, adaxially sparsely stellatefurfuraceous, dark green with prominent nervation, abaxially floccose, with dense brown stellate-tomentose hairs. Inflorescences 6-8 cm long, with 3-9 flowers; main axis terete, floccose, densely brown tomentose; primary axis $2.5-3.5 \mathrm{~cm}$ long with 1 or 2 nodes, secondary axis $1.3-1.5 \mathrm{~cm}$ long with 1 node, tertiary axis not developed; bracts oblong or lanceolate, 6-7 $\times 2-3 \mathrm{~mm}$, stellate-tomentose; bracteoles lanceolate, 5-6 × c. $2 \mathrm{~mm}$, stellate-tomentose; pedicels floccose, densely stellatetomentose, 4-5 mm long in all flowers. Hypanthium campanulate-cyathiform, 9-12 $\times$ 6-7 mm, floccose, woolly, densely covered with dense brown stellate-tomentose hairs and scattered, 1-2 mm long capitate bristles; calyx lobes triangular with subacute tip, c. $5 \times 3.5 \mathrm{~mm}$, densely stellate-tomentose, margin entire. Petals in bud conical, 


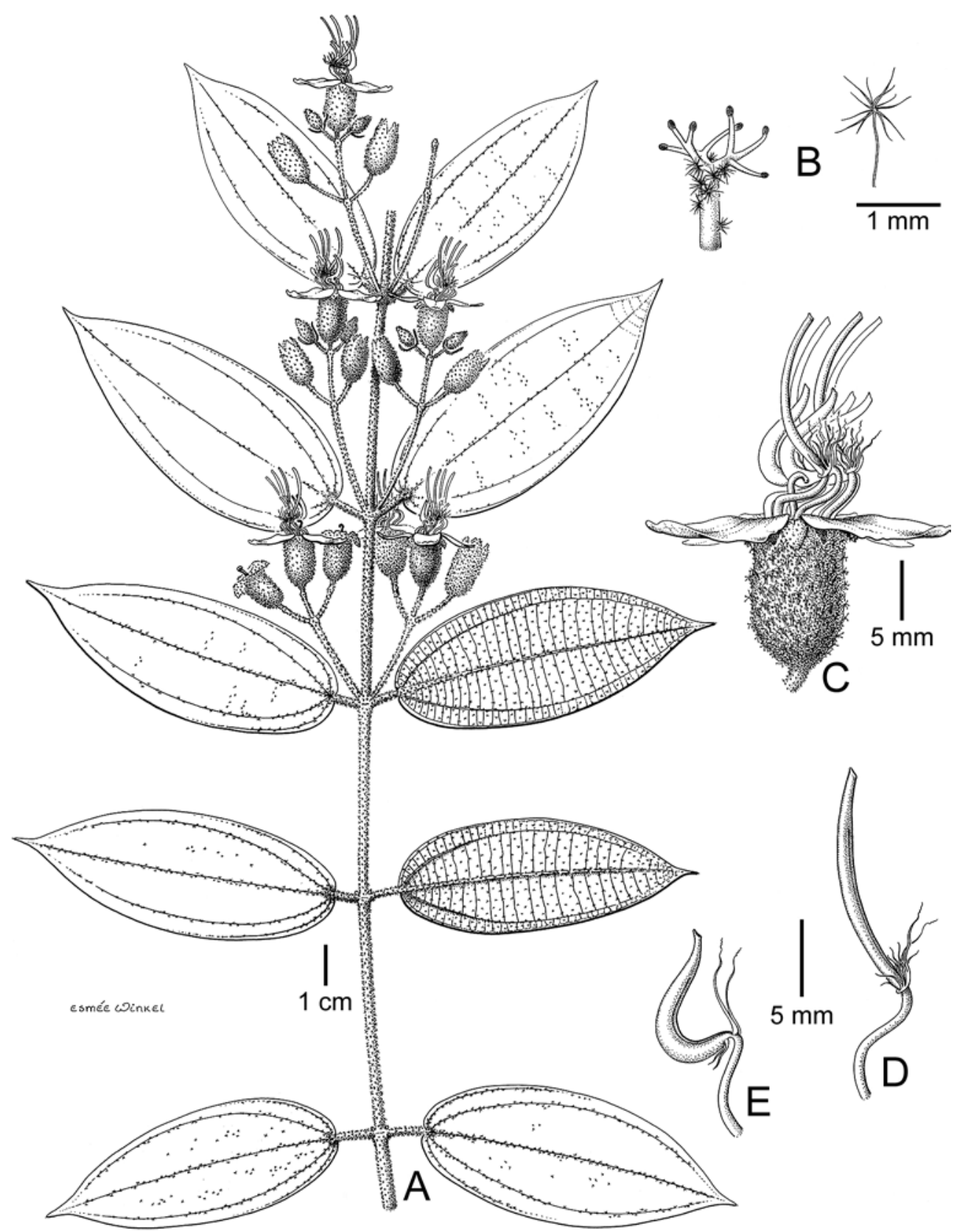

Fig. 4. Macrolenes bruneiensis Karton. A. Habit. B. Indumentum. C. Flower. D. Alternipetalous stamen. E. Oppositipetalous stamen. All from Nangkat 246 (L). Drawn by Esmée Winkel.

tip subacute, covered with stellate-furfuraceous hairs, 4-6 mm long; mature petals suborbicular, 7-9 × 7-8 mm, base clawed, apex obtuse, glabrous adaxially, half stellate-furfuraceous and half glabrous abaxially, white. Stamens : alternipetalous 
stamens with 4-5 mm long filaments, anthers curved, sickle-shaped, thecae 5-8 mm long, pedoconnective 3-4 $\mathrm{mm}$ long, connective basal crest thin, annular, prolonged into several fimbriate, filiform, 4-5 mm long appendages, laterally with paired, filiform appendages, 5-6 mm long; oppositipetalous stamens with 4-5 $\mathrm{mm}$ long filaments, anthers hooked- or S-shaped, 5-6 mm long, connective with a minute thin keel or with ligular crest, c. $0.3 \mathrm{~mm}$ long, basally with paired, filiform lateral appendages, 4-5 mm long. Ovary $3 / 4$ as long as hypanthium, apex pubescent; style 10-12 mm long, curved at tip, above glabrous, below stellate-tomentose; stigma minute, capitate; extra-ovarial chambers extending to the middle of the ovary. Fruits ovoid, 8-10 × 6-7 mm, brown, floccose, densely covered with c. $1 \mathrm{~mm}$ long erect bristle hairs covered with densely crowded, minute, brown stellate hairs; calyx lobe remnants persistent, reflexed. Seeds c. $0.5 \mathrm{~mm}$ long.

Distribution. Borneo (Brunei Darussalam).

Habitat \& ecology. Heath forest or secondary lowland dipterocarp forest at 30-300m elevation.

Etymology. Species epithet name is after the country of occurrence.

Additional specimens examined. BRUNEI: Belait: Bukit Sawat, 30 m, 11 Jul 1995, Hussain et al. BRUN 16866 (K, L); Labi, Bukit Teraja, 7 Dec 1991, Kirkup et al. 456 (K). Temburong: Amo, Bukit Tudal, 4 Oct 1994, Davis et al. 469 (K); Gunung Retak, 250 m, 26 Apr 1992, Johns et al. $7349(\mathrm{~K}, \mathrm{~L})$.

Notes. This species was initially believed to be Macrolenes pachygyna, but it differs in the bristle hairs on the hypanthium not being branched or barbed at the tip; the indumentum on the branchlets, leaves, petioles and hypanthium being rather floccose and very distinct when compared to other species; the shape of the hypanthium being rather cyathiform instead of tubular with short calyx lobes, c. $5 \mathrm{~mm}$ long, and thereby resembling $M$. tuberculata but which has a different indumentum. Macrolenes bruneiensis is known only from Brunei Darussalam, Borneo.

4. Macrolenes dimorpha (Craib) J.F.Maxwell, Gard. Bull. Singapore 33: 321 (1980). - Marumia dimorpha Craib, Bull. Misc. Inform. Kew 1930: 320 (1930); Craib, F1. Siam. Enum. 10: 696 (1931). - TYPE: Thailand, Yala, Bannang Sata, $50 \mathrm{~m}$ alt., 22 July 1923, A.F.G. Kerr 7283 (lectotype K [K000859521], designated here; isolectotypes AAU [image seen], BK [BK257159, image seen], BM [BM000944449], E [E00285930]). (Fig. 5)

Dissochaeta affinis auct. non Clausing: Clausing in Renner et al., Fl. Thailand 7(3): 421 (2001) (p.p. excl. type). 


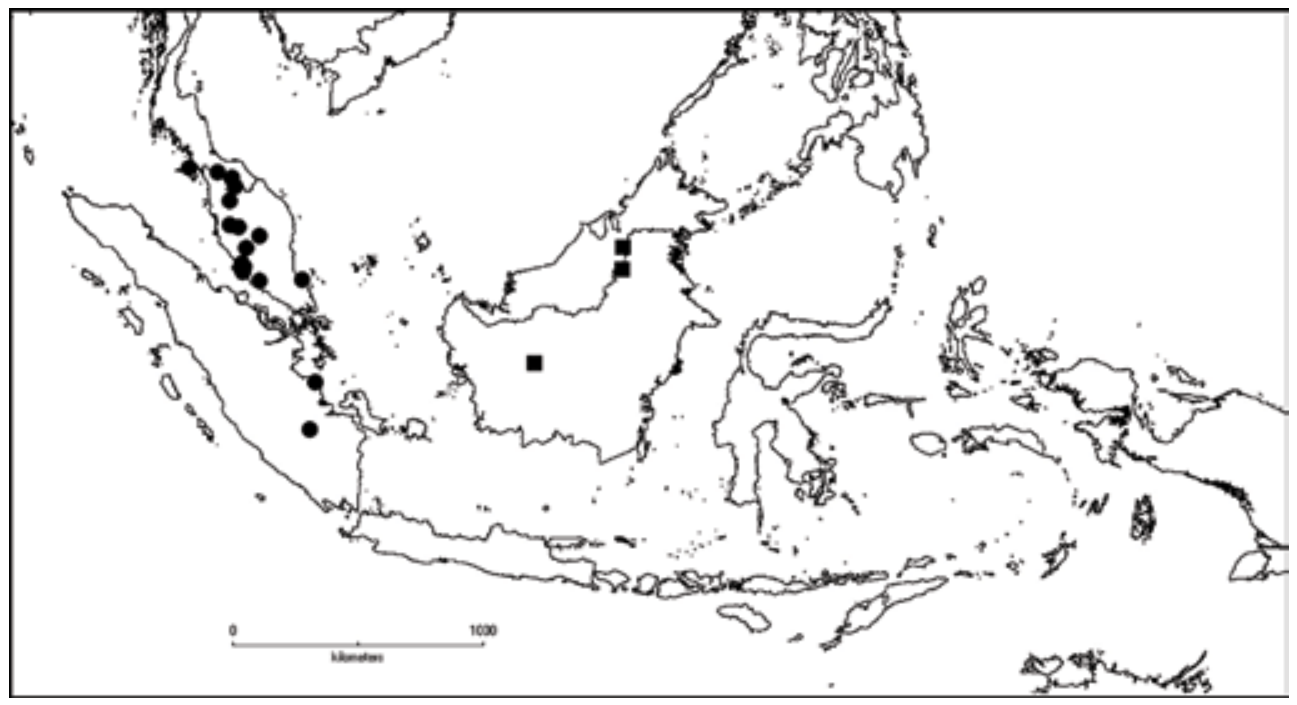

Fig. 5. Distribution of $M$. dimorpha (Craib) J.F.Maxwell (•); and M. hirsuta (Cogn.) J.F.Maxwell.

Climbing up to $6 \mathrm{~m}$ high. Branchlets terete, 3-5 $\mathrm{mm}$ in diameter, densely covered with brown stellate-tomentose hairs and scattered, c. $1 \mathrm{~mm}$ long, small, simple bristle hairs; nodes swollen, with an annular, crest-like, interpetiolar ridge; internodes 9.5-11 cm long. Leaves : petioles terete, c. $10 \mathrm{~mm}$ long, densely stellate-tomentose; blades ovate-elliptic to elliptic, 11-17 $\times 5.2-8.4 \mathrm{~cm}$, membranous, base cordate, margin entire, apex acuminate, acumen $1-1.5 \mathrm{~cm}$ long, adaxially glabrous, dark green, abaxially densely brown stellate-tomentose. Inflorescences up to $8 \mathrm{~cm}$ long, with 3-9 flowers; main axis angular, densely covered with stellate-tomentose hairs and scattered bristles; primary axis $4-8 \mathrm{~cm}$ long with $1-3$ nodes, secondary axis $0.7-1.5 \mathrm{~cm}$ long with 1 node, tertiary axis not developed; bracts ovate-elliptic, $12-17$ by $6-7 \mathrm{~mm}$, stellate-tomentose; bracteoles elliptic or elliptic-oblong, 10-12 × 4-5 mm, densely stellate-tomentose, persistent; pedicels densely brown stellate-tomentose, also with scattered bristle hairs covered with small brown stellate hairs, 3-4 mm long in central flowers, 1-2 mm long in lateral flowers. Hypanthium campanulate-tubular, 12-14 × 7-8 mm, covered with brown stellate-tomentose hairs and sparsely with 1-4 mm long simple bristle hairs completely covered with dense stellate hairs; calyx lobes slightly triangular, 9-15 × 6-8 mm, densely brown stellate-tomentose, apex acute. Petals in bud conical, 5-6 mm long, glabrous; mature petals obovate or suborbicular, 22-28 $\times$ 21-26 mm, reflexed, base clawed, apex obtuse, glabrous, white to pinkish. Stamens : alternipetalous stamens with 14-15 mm long filaments, anthers slender, sickle-shaped, thecae 22-25 mm long, white, pedoconnective 8-10 mm long, basal crest enlarged into an annular crest, prolonged into several fimbriate, filiform appendages, 9-10 mm long, laterally with paired, filiform appendages, 9-11 mm long, rarely branching at end; oppositipetalous stamens with 14-15 mm long filaments, anthers S-shaped, thick, 
thecae $18-20 \mathrm{~mm}$ long, connective with a pair of ridges or keels, c. $1 \mathrm{~mm}$ long, basally with paired, filiform lateral appendages, up to $10 \mathrm{~mm}$ long. Ovary half to $2 / 3$ as long as hypanthium, apex villous; style 20-22 mm long, curved at apex, glabrous, pink; stigma minute; extra-ovarial chambers extending from middle to base of the ovary. Fruits urceolate, c. $15 \times 10-12 \mathrm{~mm}$, densely covered with brown stellate-tomentose and simple bristle hairs covered with stellate hairs; calyx lobes persistent, reflexed. Seeds c. $0.75 \mathrm{~mm}$ long.

Distribution. Thailand (South), Peninsular Malaysia and Sumatra.

Habitat \& ecology. Disturbed lowland, swamp forest to low montane forest at road sides; 5-1550 m elevation.

Additional specimens examined. INDONESIA: Jambi: Sungai Pamusiran Dalam, 24 Feb1975, Apandi \& Undang (L). South Sumatra: Petaling, Sungai Lalang, 11 Dec 1979, Laumonier TFB 361 (L).

MALAYSIA: Johor: Mersing-Endau Road, 13 Sep 1969, Kochummen FRI 2797 (K, L). Kedah: Kroh, 120 m, 6 Aug 1941, Nauen SFN 38047 (K). Malacca: Hervey s.n. (BM). Pahang: Fraser's Hill, 1250 m, 25 Aug 1959, Burkill 2001 (K); Fraser's Hill, 1550 m, 27 Sep 1978, Maxwell 78-369 (L); Cameron Highlands, 1100 m, 21 Oct 1967, Iwatsuki et al. M-13702 (L); Cameron Highlands, 1550 m, 14 Apr 1978, Maxwell 78-140 (L); Cameron Highlands, Maxwell 78-141 (L); Rompin, Lesong FR., 200 m, Maxwell 80-77 (L). Perak: Grik, 20 Nov 1966, Ismail KEP 98508 (K, L). Selangor: Fraser's Hill, 19 Jun 1967, Carrick 1573 (K, L); Fraser's Hill, 9 Jul 1966, Stone 6402 (K, L); RRI Station, 60 m, 17 Jan 1966, Ng KEP 100016 (K, L); Klang, Bukit Changgang, 5 Oct 1937, Nur SFN 34017 (K, L, P); Puchong, 8 Feb 1968, Teo \& Purseglove 26 (K, L).

THAILAND: Satun: Teratao, 5 m, 18 Jan 1928, Kerr 14163 (BM, K). Songkhla: Ban Prakawp, 50 m, 20 Jul 1928, Kerr 15859 (BM, K, L). Yala: Bannang Sata, Khao Pok Yok, 950 m, 16 Jun 1992, Larsen et al. 42919 (P); Nikhom Kua Long, 100 m, 18 Dec 1972, Santisuk \& Nimanong 425 (K, L, P).

Notes. Macrolenes dimorpha can be distinguished by its short and unbranched bristle hairs on the hypanthium. The species resembles Macrolenes rufolanata, which also has short bristle hairs, but differs in also having dense bristle hairs on the calyx lobes, while $M$. dimorpha lacks bristles on the calyx lobes. Some specimens of Macrolenes dimorpha, collected in the montane forests of Peninsular Malaysia, have denser and longer bristle hairs on the surface of the hypanthium than the collections from the lowland.

5. Macrolenes echinulata (Naudin) Bakh.f., Contr. Melastom. 209 (1943). - Marumia echinulata Naudin, Ann. Sci. Nat., Bot. sér. 3, 15: 280 (1851); Miquel, Fl. Ned. Ind. 1(1): 534 (1855). - Dissochaeta echinulata (Naudin) Clausing in Renner et al., F1. Thailand 7(3): 425 (2001). - TYPE: Singapore, February 1837, C. GaudichaudBeaupré 79 (lectotype P [P02274823, image seen], designated here; isolectotypes G [G00319903, image seen], P [P02274821, P02274822, P02274825, P02274826, images seen]). (Fig. 6-7) 

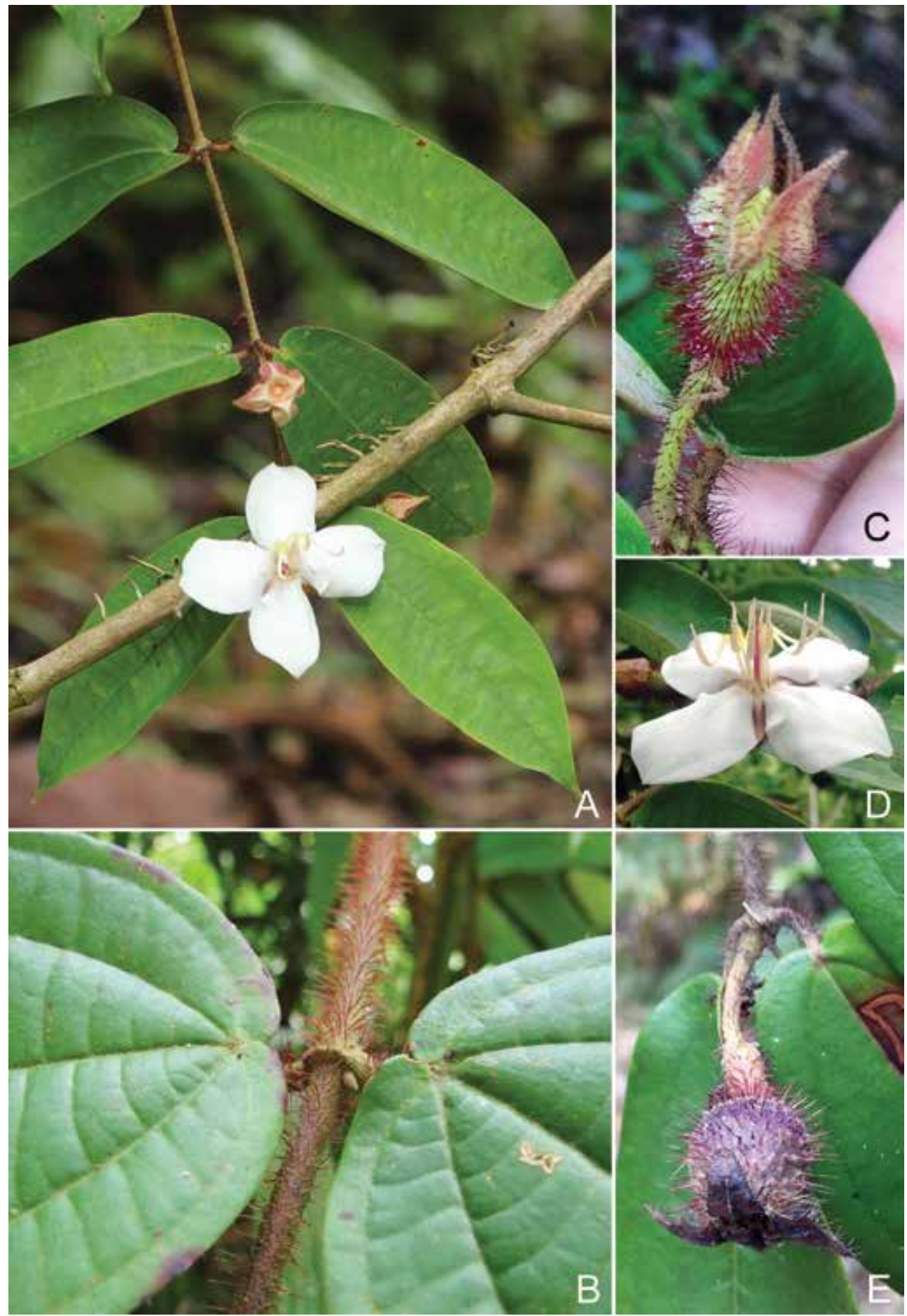

Fig. 6. Macrolenes echinulata (Naudin) Bakh.f. A. Habit. B. Branchlet. C. Hypanthium. D. flower. E. Mature fruits (Photos: C. Ng). 
Marumia rhodocarpa Wall. ex Cogn. in A.DC. \& C.DC., Monogr. Phan. 7: 550 (1891); King, J. Asiat. Soc. Bengal, Pt. 2, Nat. Hist. 69(1): 48 (1900); Koorders, Exkurs.-Fl. Java 2: 694 (1912); Ridley, Fl. Malay Penins. 1: 795 (1922). - TYPE: Singapore, N. Wallich 4045 (lectotype K-W [K000859533], designated here; isolectotype K-W [K000859532]).

Marumia sumatrana Boerl. \& Koord. in Koord.-Schum., Syst. Verz. 2: 46 (1911). - TYPE: Indonesia, Sumatra, Soengei Djati, 30 m alt., 10 March 1891, Koorders $22331 \beta$ (holotype BO [BO1294109]).

Marumia zeylanica Blume var. subglabrata C.B.Clarke in Hook.f., F1. Brit. India 2: 542 (1879). - Marumia rhodocarpa Wall. ex Cogn. var. subglabrata (C.B.Clarke) Cogn. in A.DC. \& C.DC., Monogr. Phan. 7: 551 (1891); King, J. Asiat. Soc. Bengal, Pt. 2, Nat. Hist. 69(1): 49 (1900). - TYPE: Singapore, October 1861, T. Anderson 64 (lectotype K [K000859534], designated here; isolectotypes BM [BM000944446], P [P05283589, image seen]).

Marumia zeylanica auct. non Blume: Triana, Trans. Linn. Soc. London 28(1): 82 (1872); Clarke in Hooker, Fl. Brit. India 2: 542 (1879) (all p.p. excl. type).

Climbing up to $3 \mathrm{~m}$ high. Branchlets terete, 3-4 $\mathrm{mm}$ in diameter, densely covered with stellate hairs and simple, dark maroon, 2-3 mm long bristle hairs; nodes swollen, with an interpetiolar ridge; internodes c. $4 \mathrm{~cm}$ long. Leaves: petioles flattened, 5-10 mm long, densely covered with stellate-tomentose hairs and simple bristle hairs; blades ovate to elliptic, $7.5-14 \times 3.8-5.8 \mathrm{~cm}$, subcoriaceous, base subcordate to cordate, margin entire, apex acuminate, acumen c. $1 \mathrm{~cm}$ long, adaxially glabrous, abaxially densely covered with brown stellate-tomentose hairs. Inflorescences 4-7 cm long, with 1-7 flowers; main axis angular, densely covered with stellate-tomentose hairs and bristles; primary axis $2.5-3 \mathrm{~cm}$ long with 1 or 2 nodes, secondary axis 1.5-2 $\mathrm{cm}$ long with 1 node, tertiary axis not developed; bracts leaf-like, elliptic-oblong, or linear, 4-5 × 1.2-1.6 cm when leaf-like, 5-7 mm long when linear, above glabrous, underneath stellate-tomentose; bracteoles linear or subulate, 2-4 $\mathrm{mm}$ long, densely stellate-tomentose, caducous; pedicels densely brown stellate-tomentose, 3-4 mm long in central flowers, 1-2 mm long in lateral flowers. Hypanthium campanulate, 10-12 × 5-6 mm, densely covered with brown stellate-tomentose hairs and 2-3 mm long, simple, glabrous bristle hairs; calyx lobes triangular-ovate, $7-10 \times$ c. $5 \mathrm{~mm}$, apex acute, densely brown stellate-tomentose and bristly. Petals in bud conical, c. $8 \mathrm{~mm}$ long; mature petals ovate to suborbicular, $15-18 \times 12-13 \mathrm{~mm}$, not reflexed, base clawed, apex obtuse, glabrous, white, pinkish. Stamens: alternipetalous stamens with 10-12 mm long creamy filaments, anthers slender, sickle-shaped, thecae c. $20 \mathrm{~mm}$ long, white, pedoconnective c. $5 \mathrm{~mm}$ long, connective basal crest enlarged into an annular crest with 5-7 fimbriate filiform appendages, 6-7 $\mathrm{mm}$ long, laterally with paired, filiform appendages, 6-8 $\mathrm{mm}$ long; oppositipetalous stamens with 


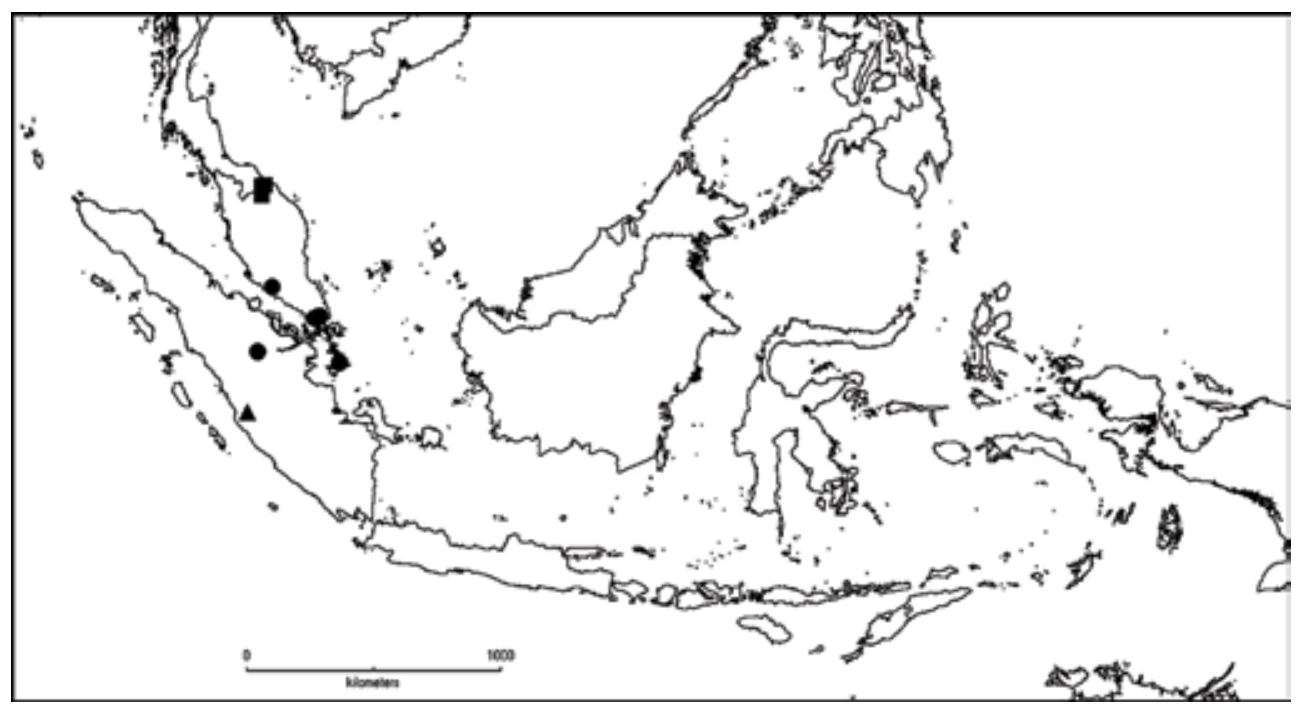

Fig. 7. Distribution of M. echinulata (Naudin) Bakh.f. (•); M. esetosa (Craib) Karton. (घ); and M. neglecta M.P.Nayar ( $\mathbf{\Delta})$.

10-12 mm long creamy filaments, anthers S-shaped, thick, thecae 10-11 mm long, connective with a pair of ridge or keels, c. $1 \mathrm{~mm}$ long, basally with paired, filiform lateral appendages, 4-6 mm long. Ovary half as long as hypanthium, apex villous; style 15-18 mm long, curved at apex, glabrous; stigma minute; extra-ovarial chambers extending from middle to base of the ovary. Fruits urceolate, 13-15 $\times 9-10 \mathrm{~mm}$, densely covered with brown stellate-tomentose and simple glabrous bristle hairs; calyx lobes persistent, reflexed. Seeds c. $0.75 \mathrm{~mm}$ long.

Distribution. Malay Peninsula and Sumatra.

Habitat \& ecology. Lowland or swampy forest, in open places at 30-40 m elevation.

Vernacular Name. Sumatra: Kemunting akar (Lingga).

Additional specimens examined. INDONESIA: Riau Archipelago: Lingga Island, Tanjung Buton, Kampung Daik, 30 m, 28 Jul 1919, Bünnemeijer 7065 (BO, K, L).

MALAYSIA: Johor: Sungai Tukong, 30 m, 28 Jul 1930, Spare 828 (K). Malacca: Cuming 2383 (K); Gaudichaud-Beaupré s.n. (P); Griffith KD 2270 (K); Maingay KD 785 (K, L).

SINGAPORE: d'Alleizette 2444 (L); Seeman 2367 (K); Anderson 68 (BM, K, P); Lobb 42 (K); Ridley 15470 (BM, K); Ridley s.n. (BM); Schomburgh 68 (BM, P); Walker 33 (BM, K); King's Collector 278 (P); 7 Sep 1879, King's Collector s.n. (K); 11 Aug 1894, Langlasse 178 (P); Jurong Road, 19 Oct 1932, Corner SFN 26035 (K); Nee Soon, 25 Jun 1978, Maxwell 78-334 (L); Seletar Reservoir, 11 Mar 1971, Noor SRMN 13 (L); Ang Mo Kio, 8 Mar 1889, Ridley 258 (BM); Mandai Road, 10 Dec 1949, Sinclair s.n. (L, P). 
Notes. Macrolenes echinulata is easily recognised by its dense simple, unbranched, dark maroon bristle hairs on the branchlets, petioles, inflorescence axes and hypanthium. The leaves are abaxially rather tomentose and lack bristles. The distribution of the species is restricted to the lowland forest of the southern part of the Malay Peninsula (Malacca, Johor and Singapore) and Sumatra (Riau and Riau Archipelago). Triana (1872) and Clarke (1879) considered this species to be a synonym of Macrolenes zeylanica (= M. annulata) because of the simple, glabrous, bristle hairs but they overlooked the difference in density and the fact that the bristle hairs in M. annulata only occur on the hypanthium, and not on the branchlets, where they are present in M. echinulata.

6. Macrolenes esetosa (Craib) Karton., comb. \& stat. nov. - Marumia rhodocarpa Wall. ex Cogn. var. esetosa Craib, Fl. Siam. Enum. 10: 697 (1931). - Macrolenes echinulata (Naudin) Bakh.f. var. esetosa (Craib) J.F.Maxwell, Gard. Bull. Singapore 33: 321 (1980). - TYPE: Thailand, Narathiwat, Sungai Padi, August 1924, D. Bourke s.n. (lectotype K [K000859518], designated here; isolectotype BK [BK257157]). (Fig. 7)

Branchlets terete, 3-5 mm in diameter, glabrescent; nodes swollen, with interpetiolar ridge; internodes 5-9.5 cm long. Leaves: petioles terete or subangular, 6-12 mm long, pubescent with minute appressed greyish stellate hairs; blades ovate to elliptic-oblong, 6-14 × 3.2-5.5 cm, membranous, base subcordate, margin entire, apex acuminate, acumen $0.5-0.7 \mathrm{~cm}$ long, adaxially glabrous, dark green, abaxially pubescent, covered with minute greyish stellate hairs. Inflorescences 3.5-4.5 cm long, with 3-5 flowers; main axis angular, covered with greyish stellate-tomentose hairs; primary axis 2-2.5 $\mathrm{cm}$ long with 1-2 nodes, secondary axis c. $0.5 \mathrm{~cm}$ long with 1 node, tertiary axis not developed; bracts lanceolate, 9-10 × 1.7-2 mm, stellate-tomentose, greyish; bracteoles subulate, c. $2 \mathrm{~mm}$ long, stellate-tomentose, caducous; pedicels stellatefurfuraceous, bristly at apex, 3-5 $\mathrm{mm}$ long in central flowers, 1-2 $\mathrm{mm}$ long in lateral flowers. Hypanthium campanulate-tubular, 8-11 $\times 5-6 \mathrm{~mm}$, densely covered with greyish stellate-tomentose hairs and 1.5-2.5 m long, brown, thick, glabrous bristle hairs; calyx lobes triangular, 4-5 × 2-3 mm, reflexed, apex acute, rarely obtuse, sparsely bristly. Petals in bud conical, 5-6 mm long, glabrous; mature petals not seen, pink to violet (Williams 17219). Stamens (in bud): alternipetalous stamens with 5-7 $\mathrm{mm}$ long filaments, anthers slender, straight, thecae 10-14 mm long, pedoconnective 2-3 mm long, connective basal crest enlarged into an annular crest with several fimbriate, filiform appendages, 2-4 $\mathrm{mm}$ long, laterally with paired, filiform appendages, c. $4 \mathrm{~mm}$ long; oppositipetalous stamens with 5-6 mm long filaments, anthers straight, thick, thecae 8-12 $\mathrm{mm}$ long, connective with a pair of ridges or keels, c. $1 \mathrm{~mm}$ long, basally with paired, filiform lateral appendages, 4-5 mm long. Ovary half as long as hypanthium, apex pubescent; style 13-15 mm long, curved at apex, glabrous; stigma minute; extra-ovarial chambers extending from middle to base of ovary. Fruits urceolate to ovoid, 10-13 × 6-8 mm, sparsely covered with greyish 
stellate-tomentose hairs and dense 1.5-2.5 mm long brown, thick, glabrous bristle hairs; calyx lobes persistent, reflexed. Seeds c. $0.5 \mathrm{~mm}$ long.

Distribution. Southern Peninsular Thailand (Narathiwat).

Habitat \& ecology. Evergreen forest on roadside.

Additional specimen examined. THAILAND: Narathiwat: Sungai Padi, 14 May 1950, Williams 17219 (K); Waeng, 27 Nov 1962, Sangkhachand, 883 (L).

Notes. Macrolenes esetosa was previously considered to be a variety of M. echinulata due to its hypanthium of minute stellate hairs and bristles that are simple without a branching tip (Craib, 1931; Maxwell, 1980b). Unlike Macrolenes echinulata, this species lacks bristle hairs on branchlets, petioles and inflorescence axes. The bristle hairs of Macrolenes esetosa are found only on the hypanthium and the upper part of the pedicels. The bristle hairs are erect and thicker than in Macrolenes echinulata, and have a golden-brown colouration, while in M. echinulata the bristle hairs are found on branchlets, petioles, inflorescence axes and hypanthium, and they are rather slender and dark maroon. The species also resembles Macrolenes annulata that also has a setose hypanthium, but $M$. esetosa differs in having a pubescent lower leaf surface and triangular calyx lobes (lower leaf surface sparsely stellate-puberulous to glabrous and calyx lobes lanceolate in M. annulata).

7. Macrolenes glabrata M.P.Nayar, J. Jap. Bot. 55: 48 (1980). - TYPE: Malaysia, Peninsular Malaysia, Selangor, Ulu Klang Ampang, 1 September 1959, Millard 1756 (holotype K; isotype KLU n.v.). (Fig. 8)

Branchlets terete, 3-6 $\mathrm{mm}$ in diameter, covered with minute brown stellatefurfuraceous hairs; nodes swollen, with an annular interpetiolar ridge; internodes 5-13 cm long. Leaves: petioles terete, 15-25 mm long, stellate-furfuraceous; blades ovate, 10-16 × 5-7 cm, subcoriaceous, base slightly cordate, margin entire, apex acuminate, acumen 1.5-2 cm long, adaxially glabrous, dark glossy green, abaxially glabrous, sparsely stellate-puberulous on midrib and veins. Inflorescences 7-10 cm long, with 3-9 flowers; main axis stellate-furfuraceous; primary axis 6-9 cm long with 1 or 2 nodes, secondary axis 1-2 cm long with 1 node or not developed, tertiary axis not developed; bracts linear, 8-10 $\mathrm{mm}$ long, stellate-furfuraceous, esetose, caducous; bracteoles linear, 4-6 mm long, stellate-furfuraceous, esetose, caducous; pedicels densely brown stellate-tomentose, 3-5 mm long in central flowers, $1-3 \mathrm{~mm}$ long in lateral flowers. Hypanthium urceolate, 10-12 $\times 6-8 \mathrm{~mm}$, densely covered with brown stellate-tomentose hairs and 5-6 mm long bristles covered with minute stellate hairs, simple or weakly barbed and branched at tips; calyx lobes triangular-ovate with acute tips, 6-8 $\times 4-5 \mathrm{~mm}$, densely covered with minute stellate hairs and bristle hairs at margin, inside glabrous. Petals in bud conical, 9-10 mm long, stellate-furfuraceous, 
apex rounded; mature petals suborbicular, 18-20 × c. $18 \mathrm{~mm}$, reflexed, base clawed, apex obtuse, glabrous inside, white with pinkish hue. Stamens: filaments white in lower half, yellow in upper half; alternipetalous stamens with c. $15 \mathrm{~mm}$ long filaments, anthers curved, sickle-shaped, thecae 20-22 mm long, pedoconnective c. $7 \mathrm{~mm}$ long, connective basal crest thin, annular, prolonged into several fimbriate, filiform appendages, 6-7 $\mathrm{mm}$ long, lateral appendages, not or poorly developed; oppositipetalous stamens with c. $12 \mathrm{~mm}$ long filaments, anthers S-shaped, thecae 14-15 mm long, connective with a thin keel crest, extended with a pair of filiform 4-5 $\mathrm{mm}$ long appendages, lateral appendages paired, filiform, c. $6 \mathrm{~mm}$ long. Ovary half as long as hypanthium, apex villous; style $23-25 \mathrm{~mm}$ long, curved at tip, glabrous, reddish; stigma minute; extra-ovarial chambers extending almost to base of ovary. Fruits urceolate, c. $15 \times 10 \mathrm{~mm}$, glabrescent and covered with simple or barbed bristle hairs; calyx lobe remnants persistent, reflexed. Seeds c. $0.75 \mathrm{~mm}$ long.

Distribution. Peninsular Malaysia (Selangor).

Habitat \& ecology. Montane forest, in open area or road side at c. $1500 \mathrm{~m}$ elevation.

Vernacular name. Akar kelompang (Selangor).

Additional specimens examined. MALAYSIA: Selangor: Ulu Gombak, 31 May 1967, Carrick 1563 (K, L); Genting Highlands, Gunung Ulu Kali, 1500 m, 3 Jun 1978, Maxwell 78-311 (L).

Notes. This species resembles Macrolenes stellulata in the bristle hairs on the hypanthium, which are simple or weakly branched or barbed at the tip, but the leaves are rather glabrous on both surfaces, not tomentose. The species is known only from the mountain area of Genting Highlands at the border of Selangor with Pahang State.

8. Macrolenes hirsuta (Cogn.) J.F.Maxwell, Gard. Bull. Singapore 33: 321 (1980). - Marumia hirsuta Cogn. in A.DC. \& C.DC., Monogr. Phan. 7: 553 (1891). - TYPE: Indonesia, Borneo, West Kalimantan, Sintang, Teijsmann HB 8658 (lectotype BO [BO1859504], designated here; isolectotypes BO [BO1859502, BO1859503], FI [FI007927, image seen], U n.v.). (Fig. 5)

Branchlets terete, 3-4 $\mathrm{mm}$ in diameter, covered with minute brown stellate-tomentose hairs and dense, prominent, thick, simple, c. $0.75 \mathrm{~mm}$ long bristle hairs; nodes swollen, with a raised annular interpetiolar ridge; internodes $4.5-6 \mathrm{~cm}$ long. Leaves: petioles terete, 5-7 mm long, densely stellate-tomentose and with scattered simple bristle hairs; blades ovate to ovate-elliptic, 11-12.5 $\times 5-5.5 \mathrm{~cm}$, coriaceous, base cordate with c. $5.7 \mathrm{~mm}$ long sinuses, margin entire, apex acuminate, acumen $1-1.5 \mathrm{~cm}$ long, adaxially glabrous, shiny green with prominent midvein and secondary veins, abaxially brown tomentose and with a pair of hair cushions at base. Inflorescences up to $7 \mathrm{~cm}$ long, with 1-3 flowers; main axis angular, with stellate-tomentose hairs 


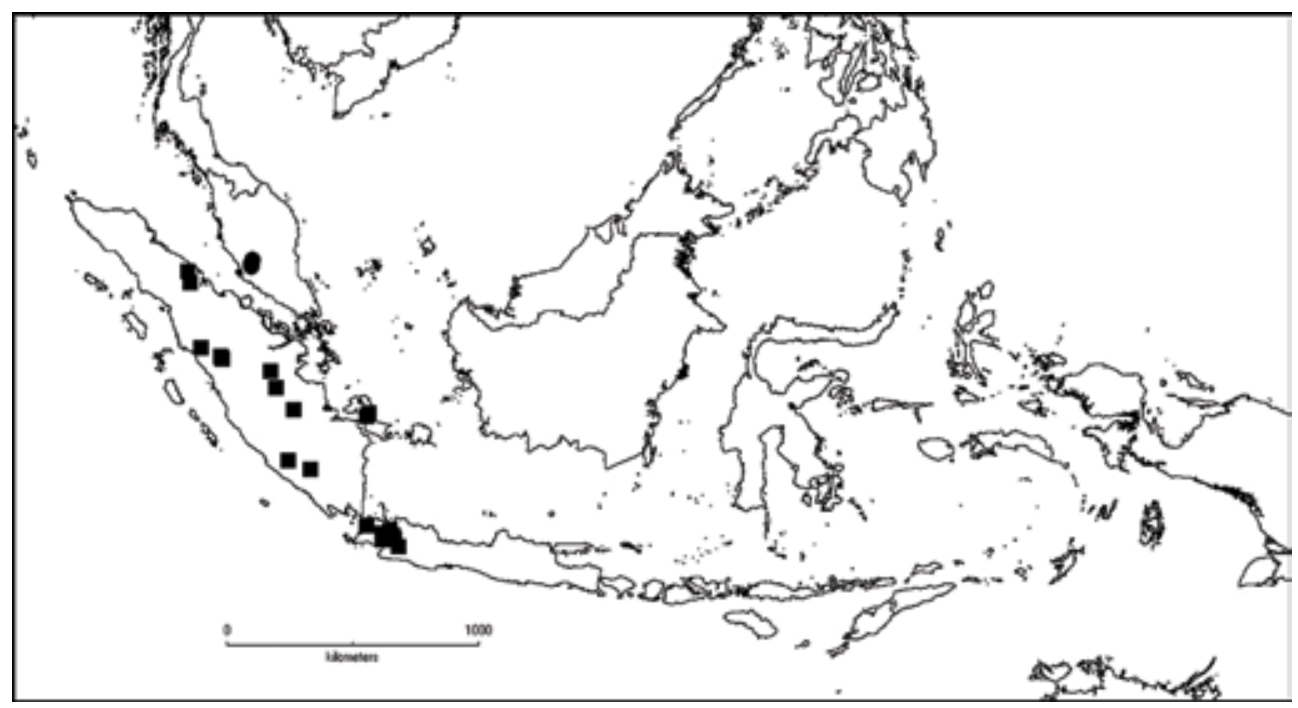

Fig. 8. Distribution of M. glabrata M.P.Nayar (•); and M. muscosa (Blume) Bakh.f. (๘).

and scattered simple bristle hairs covered with minute stellate hairs, more dense at tip that then appears to be capitate; primary axis up to $3.5 \mathrm{~cm}$ long with 1 or 2 nodes, secondary axis $1-1.5 \mathrm{~cm}$ long with 1 node, tertiary axis not developed; bracts not seen; bracteoles thin, suborbicular, 13-15 × 12-14 mm, concave, enclosing flower buds, margin serrulate, stellate-puberulous, caducous; pedicels stellate-tomentose and with scattered simple bristle hairs covered with minute stellate hairs, more dense at tip that then appears to be capitate, 2-3 mm long in central flowers, $1-2 \mathrm{~mm}$ long in lateral flowers. Hypanthium campanulate, 9-10 × 7-8 $\mathrm{mm}$, densely covered with minute stellate hairs and 3-4 mm long bristle hairs, branched or barbed at tip, latter densely covered with minute stellate hairs at tip only; calyx lobes triangular with rounded tips, 7-8 $\times 4-5 \mathrm{~mm}$, densely stellate-tomentose and with bristle hairs with branched or barbed tip, densely covered with minute brown stellate hairs. Petals in bud conical, 8-10 mm long, covered with stellate-furfuraceous hairs; mature petals not seen. Stamens: alternipetalous stamens (in bud) with 3-4 mm long filaments, anthers slender, thecae 7-8 $\mathrm{mm}$ long, pedoconnective 3-4 $\mathrm{mm}$ long, connective basal crest thin, annular, prolonged into several fimbriate, filiform appendages, 3-4 $\mathrm{mm}$ long, lateral appendages not developed; oppositipetalous stamens with 3-4 mm long filaments, anthers thick, thecae c. $7 \mathrm{~mm}$ long, connective with minute fimbriate hairs, basally with paired, filiform lateral appendages, 4-5 $\mathrm{mm}$ long. Ovary half to $3 / 4$ as long as hypanthium, apex villous; style $7-8 \mathrm{~mm}$ long, glabrous; stigma minute, capitate; extra-ovarial chambers extending almost to base of ovary. Fruits urceolate, 12-14 × 9-10 mm, densely covered with minute stellate hairs and 3-4 mm long simple bristle hairs with branched or barbed tip, densely covered with minute stellate hairs; calyx lobe remnants persistent, reflexed. Seeds c. $0.75 \mathrm{~mm}$ long. 
Distribution. Borneo.

Habitat \& ecology. Lower montane dipterocarp forest, in open areas or edges at c. $950 \mathrm{~m}$ elevation.

Additional specimens examined. INDONESIA: North Kalimantan: Malinau, Kayan Mentarang, 950 m, 26 Nov 1991, van Valkenburg \& Stockdale 1081 (K, L).

MALAYSIA: Sarawak: Bario, Kelabit Highlands, trail to Pa Ukat, 12 Apr 1995, Latiff et al. $4237(\mathrm{~K})$.

Notes. Macrolenes hirsuta is distinct by the dense, erect and thick, prominent bristle hairs on the branchlets, petioles and inflorescence axes. The bristles are thicker than those of Macrolenes bipulvinata and M. echinulata. The shape and the indumentum of the hypanthium are similar to those in Macrolenes veldkampii but the latter lacks bristles on the branchlets and petioles.

9. Macrolenes muscosa (Blume) Bakh.f., Contr. Melastom. 211 (1943); Bakhuizen van den Brink in Backer \& Bakhuizen van den Brink, Fl. Java 1: 363 (1964); Nayar, J. Jap. Bot. 55: 48 (1980). - Melastoma muscosum Blume, Bijdr. Fl. Ned. Ind. 17: 1070 (1826); DC., Prodr. 3: 148 (1828). - Marumia muscosa (Blume) Blume, Flora 14: 504 (1831); Blume, Rumphia 1: 17, t. 4 (1835); Naudin, Ann. Sci. Nat., Bot. sér. 3, 15: 280 (1851); Miquel, Fl. Ned. Ind. 1(1): 534 (1855); Triana, Trans. Linn. Soc. London 28(1): 82 (1872); Cogniaux in Boerlage, Handl. Fl. Ned. Ind. 2: 532 (1890); Cogniaux in de Candolle \& de Candolle, Monogr. Phan. 7: 551 (1891); Koorders, Exkurs.-Fl. Java 2: 694 (1912); Hochreutiner, Candollea 2: 471 (1924). - Dissochaeta muscosa (Blume) G.Kadereit in Mabberley, Pl.-Book 1101 (2017). - TYPE: Indonesia, Java, Blume s.n. (lectotype L [L0008927], first step designated by Bakhuizen van den Brink in Contr. Melastom. 212 (1943); second step designated here; isolectotypes $\mathrm{K}$ [K000867117, K000867118], M, MPU [MPU-013522, MPU-013523, images seen], P [P05283626, P05283627, P05283629, images seen]). (Fig. 8-9)

Macrolenes magnibracteata Bakh.f., Contr. Melastom. 209 (1943). - TYPE: Indonesia, Sumatra, Ophir District, N of Taloe, 950 m alt., 10 April 1917, Bünnemeijer 96 (holotype L [L0537195]; isotypes BO [BO1849059, BO1849060).

Climbing up to $10 \mathrm{~m}$ high. Branchlets terete, 3-6 $\mathrm{mm}$ in diameter, densely covered with brown minute stellate-furfuraceous hairs; nodes swollen, with interpetiolar ridge; internodes 3-7.5 cm long. Leaves: petioles terete, c. $10 \mathrm{~mm}$ long, densely brown stellate-tomentose; blades ovate to oblong, $8-15 \times 3.5-6 \mathrm{~cm}$, subcoriaceous, base rounded to shallowly subcordate, margin entire, apex acuminate, acumen c. $1 \mathrm{~cm}$ long, adaxially mostly glabrous or with stellate hairs on veins, abaxially densely brown stellate-tomentose. Inflorescences 5-7 cm long, with 1-9 flowers; main axis angular, 


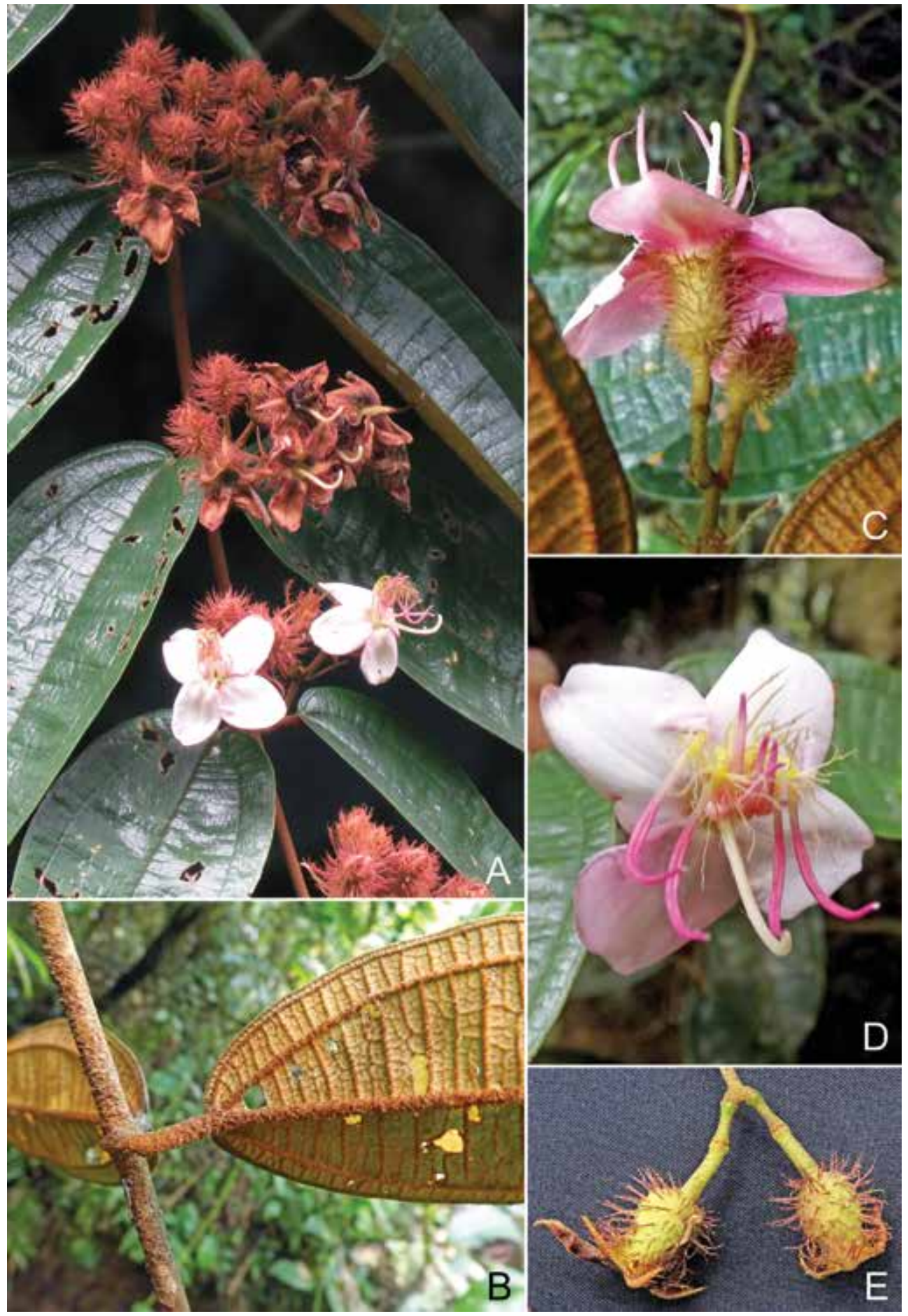

Fig. 9. Macrolenes muscosa (Blume) Bakh.f. A. Habit. B. Branchlet. C. Hypanthium. D. Flower. E. Immature fruits. (Photos A, E from Z. Al Anshori; B, C \& D, A. Kartonegoro). 
densely brown stellate-tomentose; primary axis 2-3 cm long with 1 node, secondary axis up to $1 \mathrm{~cm}$ long with 1 node or not developed, tertiary axis not developed; bracts lanceolate or oblong, 10-20 $\times 3-7 \mathrm{~mm}$, brown stellate-tomentose, caducous; bracteoles linear or oblong, 6-8 mm long, stellate-tomentose; pedicels densely stellate-tomentose, 4-6 mm long in central flowers, 2-4 mm long in lateral flowers. Hypanthium campanulate-tubular, 10-12 × 5-6 mm, densely covered with brown stellatetomentum hairs and simple, 4-5 $\mathrm{mm}$ long bristles covered with brown stellate hairs; calyx lobes triangular with acute tips, 5-6 $\times 2-3 \mathrm{~mm}$, densely covered with brown minute stellate hairs, margin laciniate. Petals in bud conical, 4-6 mm long, brown tomentose or pubescent; mature petals ovate to elliptic, 13-15 $\times 8-11 \mathrm{~mm}$, base clawed, apex obtuse, glabrous adaxially, half glabrous and half pubescent abaxially, white or bright pink. Stamens: alternipetalous stamens with 10-11 mm long filaments, anthers curved, sickle-shaped, thecae 18-20 mm long, apex rostrate, pedoconnective 4-5 mm long, connective basal crest thin, enlarged, annular, rounded, with several fimbriate, filiform appendages, up to $9 \mathrm{~mm}$ long, lateral appendages paired, filiform, 8-9 mm long; oppositipetalous stamens with 9-10 mm long filaments, anthers hookor S-shaped, 11-13 mm long, connective with a thin keel crest, c. $1 \mathrm{~mm}$ long, lateral appendages paired, filiform, c. $5 \mathrm{~mm}$ long. Ovary half as long as hypanthium, apex villous; style 18-22 mm long, curved at tip, glabrous; stigma minute; extra-ovarial chambers extending from middle to base of ovary. Fruits urceolate, $14-15 \times 7-8$ $\mathrm{mm}$, brown, densely covered with stellate-tomentose hairs and simple, 4-5 mm long bristles covered with brown stellate hairs; calyx lobe remnants persistent, reflexed. Seeds c. $0.75 \mathrm{~mm}$ long.

Distribution. Sumatra and West Java.

Habitat \& ecology. Lowland forest to lower montane forest, in open places; 50-1000 $\mathrm{m}$ elevation.

Vernacular names. Java: Areuy caluncung, caluncung beureum, harendong badak, harendong bulu (Sunda).

Additional specimens examined. INDONESIA: Bangka-Belitung: Bangka Island, Gunung Mangkol, 50 m, 12 Sep 1949, Kostermans \& Anta 620 (BO, K, L, P); Bangka Island, Gunung Mangkol, 50 m, 15 Sep 1949, Kostermans \& Anta 734 (BO, K, L). Jambi: 100 m, 18 Aug 1925, Posthumus 715 (BO, L); Harapan Rain Forest, 6 Apr 2013, Wardi BOHK 471 (BO, K). North Sumatra: Labuhan Batu, Aek Kanopan, Lundut, 23 Mar 1927, Bartlett 7050a (K, L); Labuhan Batu, Aek Kanopan, Lundut, 23 Mar 1927, Bartlett 7296 (K, L); Asahan, Kuala Masihi, Yates 2278 (BM). Riau: Indragiri Hulu, Muara Pajanki, 9 Apr 1939, Buwalda 6450 (BO, K, L). South Sumatra: Ogan Ulu, Teijsmann HB 3958 (BO, K, U); Tanjung Enim, Seleman, 150 m, 10 Mar 1972, de Vogel 1224 (BO, K, L). West Sumatra: Taram, Kapalo Banda, 1 Apr 1988, Delita et al. 7 (ANDA); Lima Puluh Kota, Harau Valley, 500 m, 12 Dec 1956, Meijer 5391 (L). Banten: Gunung Seribu, Blume s.n. (L). West Java: Bogor, Bolang, 600 m, 11 May 1924, Docters van Leeuwen 7907 (BO, K, L); Bogor, Cianten, Gunung Batu, 31 Aug 1918, Backer 25794 (BO, L); Bogor, Gunung Kembang, 22 Jun 1924, Bakhuizen van 
den Brink 3410 (BO, U); Bogor, Puraseda, Ranca Badak, 450 m, 2 Feb 1929, Bakhuizen van den Brink 7033 (BO, K, L); Bogor, Parungpung, 750 m, 22 Dec 1930, Bakhuizen van den Brink 7696 (BO, L); Bogor, Mount Halimun, Nirmala Plantation, 1000 m, 10 Jun 1980, van Balgooy \& Wiriadinata 2944 (BO, L); Bogor, Mount Halimun, Nirmala Plantation, 1100 m, 1 Nov 2014, Arief 302 (BO, PE); Bogor, Mount Halimun, Nirmala Plantation, 1100 m, Nov 1997, Suzuki K11066 (L); Bogor, Mount Halimun, Malasari, 1055 m, 10 Oct 2017, Kartonegoro 1108 (BO, L); Bogor, Mount Salak, 950 m, 10 Apr 1904, Hochreutiner 771 (L); Bogor, Tapos, Junghuhn s.n. (L, U); Cianjur, Cidadap, Cadas Malang, 1000 m, 20 Oct 1916, Bakhuizen van den Brink 1858 (BO, L); Cianjur, Cidadap, Cadas Malang, 1000 m, 1 May 1923, Winckel 1302 (BO, K, L, U); Cianjur, Cidadap, Cadas Malang, 1000 m, 18 May 1917, Winckel s.n. (L); Depok, Pancoran Mas Nature Reserve, 93 m, 31 May 1924, Beumée 6729 (BO, L); Sukabumi, Cibadak, Kelapa Nunggal, 800 m, 18 Apr 1974, Wiriadinata 89 (BO, K, L). Unknown location (Java): Boerlage s.n. (L); Blume s.n. (L); Junghuhn 742 (K); Kuhl \& van Hasselt 56 (L); Spanoghe s.n. (K); de Vriese 72 (L); de Vriese 96 (L); de Vriese 110 (L); Zollinger 1409 (BM, P).

Notes. Macrolenes muscosa resembles $M$. dimorpha in its simple bristle hairs on the hypanthium, which are covered by minute stellate hairs. However, the bristles on Macrolenes muscosa are longer (4-5 mm long) than those of M. dimorpha (1-4 mm long). The calyx lobes and bracteoles of Macrolenes muscosa are usually covered with bristle hairs and are ciliate at the margin. The bracts and bracteoles of the specimens from Sumatra are larger and are more oblong-shaped than the Javan specimens that are smaller and rather linear or lanceolate.

10. Macrolenes neglecta M.P.Nayar, J. Jap. Bot. 55: 46 (1980). - Type: Indonesia, Sumatra, Korinchi, Sungei Kumbang, $4500 \mathrm{ft}$ alt., 10 April 1914, H.C. Robinson \& C. Boden-Kloss s.n. (holotype BM [BM000944488]; isotype K [K000867115]). (Fig. 7)

Branchlets terete, 3-5 $\mathrm{mm}$ in diameter, brown stellate-furfuraceous; nodes swollen, with an annular crest-like interpetiolar ridge; internodes $8-11 \mathrm{~cm}$ long. Leaves: petioles terete, 8-10 mm long, brown stellate-tomentose; blades ovate, 6-9 × 3-4.7 $\mathrm{cm}$, coriaceous, base shallowly cordate, margin entire, apex acuminate, acumen c. $0.5 \mathrm{~cm}$ long, adaxially glabrous, dark green, abaxially densely stellate-tomentose. Inflorescences up to $9 \mathrm{~cm}$ long, with 1-3 flowers; main axis angular, terete, brown stellate-furfuraceous; primary axis up to $7.5 \mathrm{~cm}$ long with 1 or 2 nodes, secondary axis when developed $1-1.5 \mathrm{~cm}$ long with 1 node; bracts and bracteoles ovate, 8-9 $\times$ 6-7 mm, glabrous, thin, margin serrate, apex acute, persistent; pedicels stellatefurfuraceous, 2-3 mm long in central flowers, 1-2 $\mathrm{mm}$ long in lateral flowers. Hypanthium tubular, 8-9 $\times$ 4-5 mm, covered with stellate-furfuraceous hairs and dark simple, glabrous, $1.5-2 \mathrm{~mm}$ long bristle hairs; calyx lobes ovate or triangular, 7-8 $\times$ 4-5 mm, margin serrate, apex acute, glabrous. Petals in bud conical, 5-7 mm long; mature petals suborbicular, 14-15 × c. $14 \mathrm{~mm}$, base clawed, apex obtuse, glabrous, pink. Stamens: alternipetalous stamens with c. $12 \mathrm{~mm}$ long filaments, anthers slender, sickle-shaped, thecae 16-17 mm long, pedoconnective c. $5 \mathrm{~mm}$ long, connective basal crest small with several fimbriate, filiform appendages, 4-5 mm long, 
lateral appendages paired, filiform, c. $5 \mathrm{~mm}$ long; oppositipetalous stamens with c. 10 $\mathrm{mm}$ long filaments, anthers S-shaped, thick, thecae 11-13 $\mathrm{mm}$ long, connective with a pair of ridges or keels, c. $0.5 \mathrm{~mm}$ long, lateral appendages paired, filiform, $4-5 \mathrm{~mm}$ long. Ovary half as long as hypanthium, apex villous; style 15-17 $\mathrm{mm}$ long, curved at apex, glabrous; stigma minute; extra-ovarial chambers extending from middle to base of ovary. Fruits and seeds not seen.

Distribution. Sumatra (Kerinci Range).

Habitat \& ecology. Montane forest at c. 1300 m elevation.

Notes. Known only from the type from the Kerinci Range in Western Sumatra. The species typically resembles Macrolenes annulata with its simple, glabrous bristle hairs and triangular-ovate calyx lobes. However, the leaves of Macrolenes neglecta are subcoriaceous and densely covered with stellate-tomentose hairs on the blade beneath, while $M$. annulata has membranous, glabrous leaves.

11. Macrolenes nemorosa (Jack) Bakh.f., Contr. Melastom. 206 (1943); Nayar, J. Jap. Bot. 55: 50 (1980). - Melastoma nemorosum Jack, Trans. Linn. Soc. London 14: 8 (1823), as 'nemorosa'; de Candolle, Prodr. 3: 149 (1828). - Marumia nemorosa (Jack) Blume, Flora 14: 505 (1831); Blume, Mus. Bot. 1(3): 33 (1849); Naudin, Ann. Sci. Nat., Bot. sér. 3, 15: 279 (1851); Miquel, Fl. Ned. Ind. 1(1): 533 (1855); Triana, Trans. Linn. Soc. London 28(1): 82 (1872); Clarke in Hooker, F1. Brit. India 2: 542 (1879); Cogniaux in Boerlage, Handl. Fl. Ned. Ind. 2: 532 (1890); Cogniaux in de Candolle \& de Candolle, Monogr. Phan. 7: 549 (1891); King, J. Asiat. Soc. Bengal, Pt. 2, Nat. Hist. 69(1): 47 (1900); Ridley, Fl. Malay Penins. 1: 795 (1922). - TYPE: Malaysia, Penang, Jack 51 (lectotype BM [BM000944447], designated by Nayar in J. Jap. Bot. 55: 50 (1980)). (Fig. 10-11)

Marumia affinis Korth. in Temminck, Verh. Nat. Gesch. Ned. Bezitt., Bot. t. 60 (1842); Naudin, Ann. Sci. Nat., Bot. sér. 3, 15: 282 (1851); Miquel, Fl. Ned. Ind. 1(1): 533 (1855). - Dissochaeta affinis (Korth.) Clausing in Renner et al., Fl. Thailand 7(3): 421 (2001). - TYPE: Indonesia, Borneo, Bandjermasin, G. Sakoembang, P.W. Korthals s.n. (lectotype L [L0537251], first step designated by Bakhuizen van den Brink in Contr. Melastom. 207 (1943); second step designated by Turner in Taxon 67: 628 (2018); isolectotypes K [K000859511, K000859513, K000859516, K000859517], L [L0537252], P [P05283673, P05283676, images seen]).

Marumia leprosa Korth. in Temminck, Verh. Nat. Gesch. Ned. Bezitt., Bot. 241 (1844); Blume, Mus. Bot. 1(3): 34 (1849); Naudin, Ann. Sci. Nat., Bot. sér. 3, 15: 283 (1851); Miquel, F1. Ned. Ind. 1(1): 533 (1855); Triana, Trans. Linn. Soc. London 28(1): 82 (1872); Cogniaux in Boerlage, Handl. Fl. Ned. Ind. 2:532 (1890); Cogniaux in de Candolle \& de Candolle, Monogr. Phan. 7: 549 (1891). - Macrolenes nemorosa 


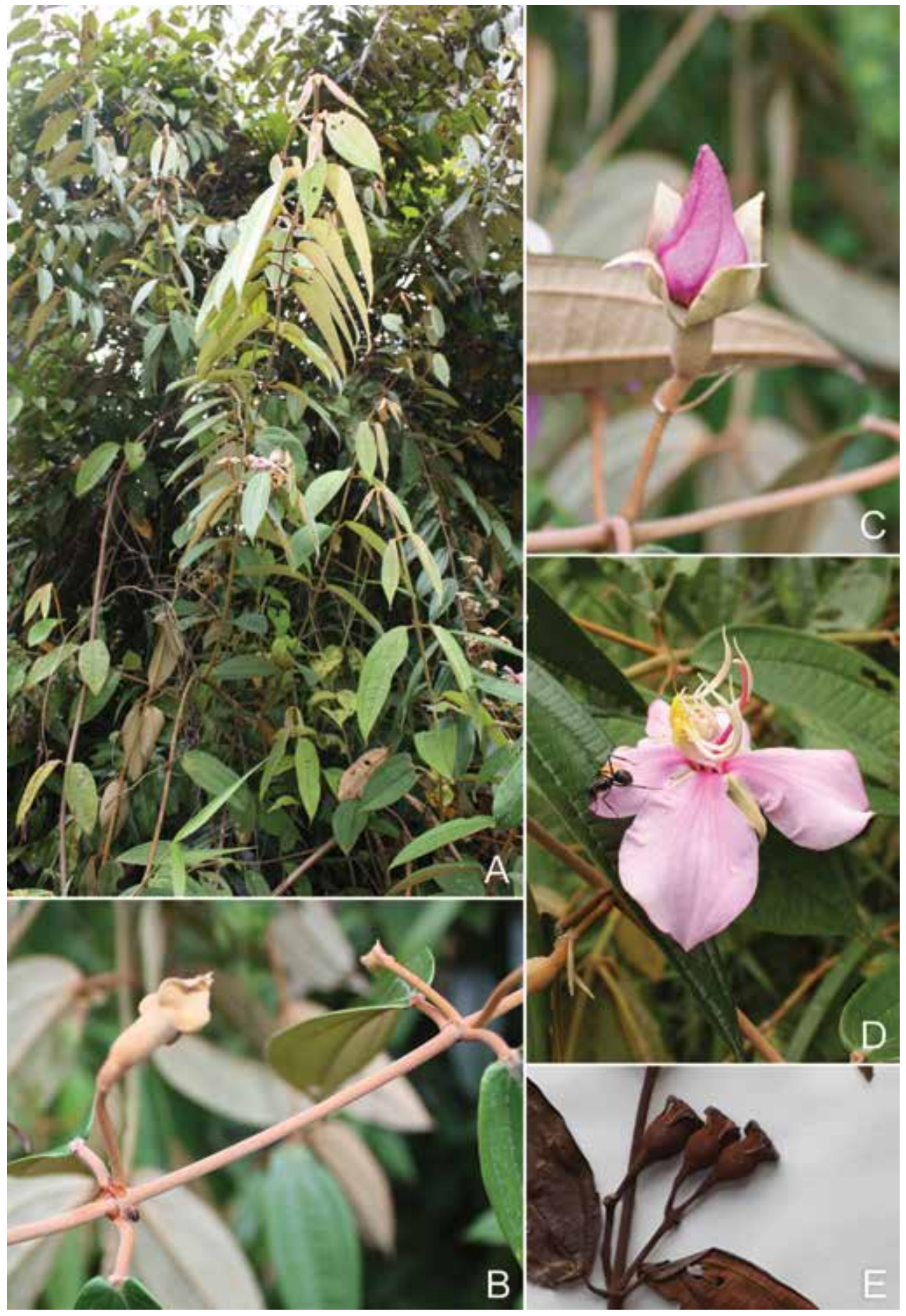

Fig. 10. Macrolenes nemorosa (Jack) Bakh.f. A. Habit. B. Branchlet. C. Hypanthium. D. flower. E. Fruits. E from Hardial \& Sidek 383 (K). (Photos: A. Kartonegoro). 
(Jack) Bakh.f. var. leprosa (Korth.) Bakh.f., Contr. Melastom. 208 (1943); Nayar, J. Jap. Bot. 55: 51 (1980). - TYPE: Indonesia, Borneo, Bandjermasin, G. Sakoembang, P.W. Korthals s.n. (lectotype L [L0537253], first step designated by Bakhuizen van den Brink in Contr. Melastom. 208 (1943); second step designated here; isolectotypes BO [BO1769284], K [K000859511, K000859513, K000859514], L [L0008931, L053725], MPU [MPU-013526, image seen], P [P05283622, P05283623, images seen], S [SG-3964, image seen]).

Marumia bancana Scheff., Natuurk. Tijdschr. Ned.-Indië 31: 355 (1870). - Macrolenes nemorosa (Jack) Bakh.f. var. bancana (Scheff.) Bakh.f., Contr. Melastom. 207 (1943); Nayar, J. Jap. Bot. 55: 50 (1980). - TYPE: Indonesia, Sumatra, Bangka, Djeboes, J.E. Teijsmann s.n. (lectotype L n.v., designated by Bakhuizen van den Brink in Contr. Melastom. 208(1943); isolectotypes BO [BO1769279, BO1769280], K[K000859515]).

Marumia verrucosa Cogn. in A.DC. \& C.DC., Monogr. Phan. 7:549 (1891). - Marumia nemorosa (Jack) Blume var. verrucosa (Cogn.) Ridl., Fl. Malay Penins. 1: 795 (1922). - TYPE: Malaysia, Peninsular Malaysia, Malacca, Klang, Kehding 091 (lectotype FI [FI008754, image seen], designated here; isolectotypes BR [BR519628, image seen]).

Marumia impressa Craib, Bull. Misc. Inform. Kew 1930: 321 (1930); Craib, Fl. Siam. Enum. 10: 696 (1931); Furtado, Gard. Bull. Singapore 20: 116 (1963). - TYPE: Thailand, Phang Nga, Kapong, Takuapa, 100 m alt., 17 February 1929, A.F.G. Kerr 17110 (lectotype K [K000859519], designated here; isolectotypes BK [BK257158, image seen], BM [BM000944448], K [K000859520]).

Climbing up to $12 \mathrm{~m}$ high. Branchlets terete, 3-4 $\mathrm{mm}$ in diameter, covered with brown stellate-furfuraceous hairs; nodes swollen, with interpetiolar ridges; internodes 7.5-10 cm long. Leaves: petioles flattened, 8-10 mm long, densely stellate-tomentose; blades ovate-elliptic to elliptic, $8-16 \times 3.8-9 \mathrm{~cm}$, membranous or subcoriaceous, base rounded to shallowly subcordate, margin entire, apex acuminate, acumen up to 0.5 $\mathrm{cm}$ long, adaxially mostly glabrous or with stellate hairs on veins, abaxially densely stellate-tomentose. Inflorescences 5-8 cm long, with 1-3 flowers; main axis densely stellate-tomentose; primary axis $3-3.5 \mathrm{~cm}$ long with 1 node, secondary axis $1-1.8$ $\mathrm{cm}$ long with 1 node or not developed, tertiary axis not developed; bracts lanceolate, 12-15 × c. $4 \mathrm{~mm}$ long, stellate-tomentose, caducous; bracteoles subulate or oblong, 3-4 mm long, stellate-tomentose, caducous; pedicels densely stellate-tomentose, 2-4 $\mathrm{mm}$ long in central flowers, c. $1 \mathrm{~mm}$ long or subsessile in lateral flowers. Hypanthium campanulate-tubular or suburceolate, $8-15 \times 5-7 \mathrm{~mm}$, villous, densely covered with stellate-tomentum only; calyx lobes triangular with acute or acuminate tips, $7-15 \times$ 3-6 mm, densely covered with minute stellate hairs. Petals in bud conical, 7-9 mm long; mature petals suborbicular, 20-25 × 18-20 mm, reflexed, base clawed, apex obtuse, glabrous, white-pinkish to pink. Stamens: alternipetalous stamens with 10-11 $\mathrm{mm}$ long yellow filaments, anthers curved, sickle-shaped, thecae 18-20 mm long, 


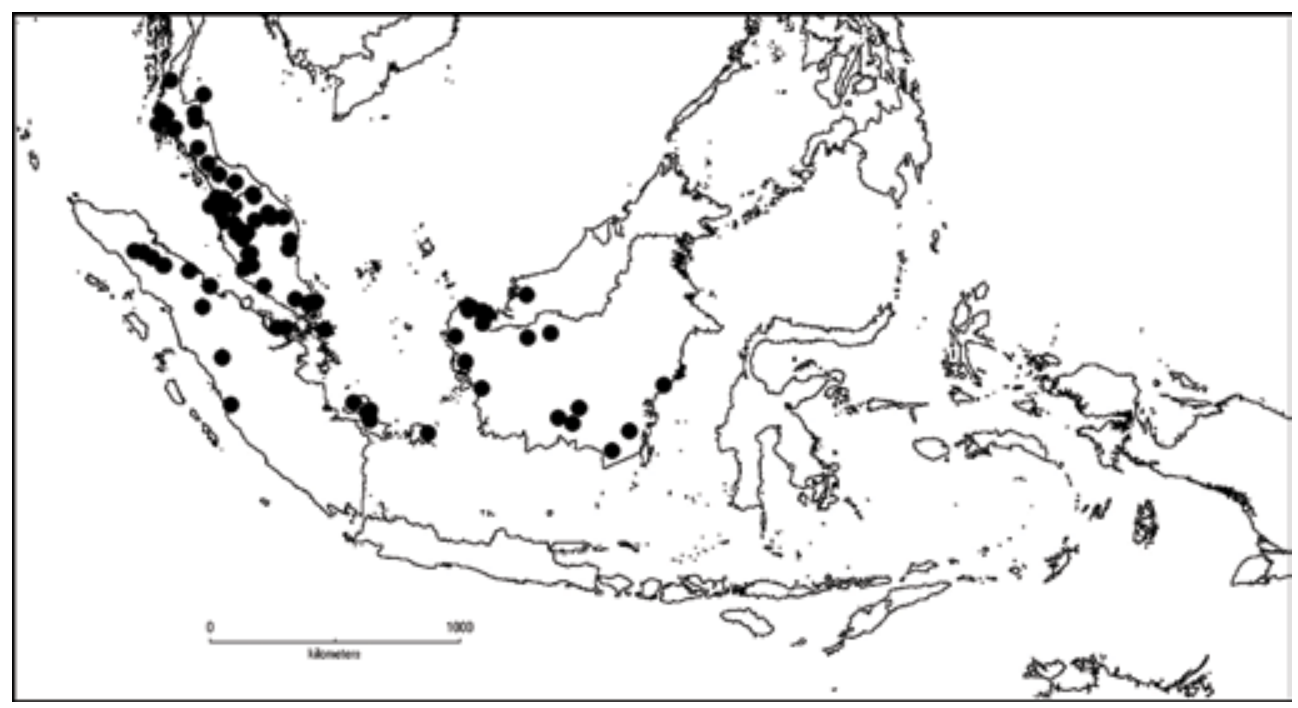

Fig. 11. Distribution of M. nemorosa (Jack) Bakh.f. (•).

yellow, apex rostrate, pedoconnective 7-8 $\mathrm{mm}$ long, connective basal crest thin, enlarged, annular, rounded, with fimbriate, filiform, up to $5 \mathrm{~mm}$ long appendages, lateral appendages paired, filiform, 6-7 mm long; oppositipetalous stamens with c. 10 $\mathrm{mm}$ long yellow filaments, anthers S-shaped, 13-15 mm long, connective with a thin keel crest, up to $2 \mathrm{~mm}$ long, lateral appendages paired, filiform, 5-6 mm long. Ovary $1 / 3$ to half as long as hypanthium, apex pubescent; style 20-22 $\mathrm{mm}$ long, curved at tip, glabrous; stigma minute; extra-ovarial chambers extending almost to base of ovary. Fruits urceolate, 10-15 $\times 7-10 \mathrm{~mm}$, brown, densely covered with stellate-tomentose hairs only; calyx lobe remnants persistent, reflexed. Seeds c. $0.75 \mathrm{~mm}$ long.

Distribution. Thailand (Southern Peninsula), Peninsular Malaysia, Sumatra and Borneo.

Habitat \& ecology. Disturbed evergreen lowland forest to lower montane forest, heath forest, peat swamps, riverine forest, roadsides; 10-1250 m elevation.

Vernacular names. Peninsular Malaysia: Banga utan. Sumatra: pancung pelangit (Bengkalis), akar penangil (Bangka). Borneo: kemasulan (Katingan), mangkodok (Sarawak).

Additional specimens examined. INDONESIA: Aceh: Mount Leuser National Park, Gunung Kemiri, 10 Mar 2008, Sumadijaya 342 (BO); Mount Leuser National Park, Gunung Bandahara, 1000 m, 27 Jun 1972, de Wilde \& de Wilde-Duyfjes 13414 (K, L). Bangka-Belitung: Bangka Island, Batu Rusak, Berkhout s.n. (BO); Bangka Island, Melabun, 80 m, 15 Nov 1917, Bünnemeijer 1989 (BO, L); Bangka Island, Sungai Selan, Teijsmann s.n. (BO, L); Belitung Island, Manggar, Teijsmann s.n. (BO). North Sumatra: Yates 1207 (BM, K, L); Sibolangit, 
900 m, 13 Oct 1917, Lörzing 5333 (BO, L); Mount Sibayak, Bandar Baru, 900 m, 10 Oct 1928, Lörzing 14128 (BO, K, L); Labuan Bilik, Bila, 8 Oct 1928, Lörzing 14308 (BO, K, L); Labuhan Batu, Kota Pinang, Langga Payung, Mar 1933, Rahmat Si Toroes 3287 (L); Labuhan Batu, Kota Pinang, Langga Payung, Mar 1933, Rahmat Si Toroes 3403 (L); Bohorok, Bukit Lawang, 17 Feb 1973, Soedarsono 245 (BO, L). Riau: Rangsang Island, 24 Jul 1918, Bruinier 39 (BO); Rangsang Island, 24 Jul 1918, Bruinier 92 (BO). Riau Archipelago: Bengkalis, Selat Panjang, 15 Nov 1919, Beguin 473 (BO); Dompak Island, 10 m, 24 Jun 1919, Bünnemeijer 6416 (BO, L). West Sumatra: Korthals s.n. (P); Lima Puluh Kota, Harau Valley, Sarasah Bonta, 500 m, 27 Apr 2002, Silvia et al. 35 (ANDA); Lima Puluh Kota, Harau Valley, Sarasah Bonta, 500 m, 11 Sep 2017, Kartonegoro 1070 (BO, L); Lima Puluh Kota, Harau Valley, Sarasah Bonta, 500 m, 12 Sep 2017, Kartonegoro 1097 (BO, L). Central Kalimantan: Sampit, Cempaka Mulia, 20 Jan 1954, Alston 13135 (BM, L, PNH); Sei Gohong, Rungun River, 50 m, 14 Jan 2001, Sidiyasa et al. 2418 A (L); Sebangau National Park, Katingan River, Sungai Landabung, 15 Mar 2007, Wardani \& Amir 554 (BO). East Kalimantan: Balikpapan, Sungai Wain, 200 m, 16 Jan 2005, Bernard et al. RC\#4 (L). South Kalimantan: Mount Pamatton, Korthals s.n. (L); Mount Sakumbang, Korthals s.n. (L). West Kalimantan: Ulu Kenepai, Hallier 1442 (BO, L); Rasau Jaya, Sungai Punggur Besar, 8 Nov 1976, Kartawinata 1421 (BO, K, L); Kapuas Hulu, Pentulak Lake, 7 Oct 1949, Main 1951 (BO, K, L); Ketapang, Gunung Palung National Park, Cabang Panti, 20 m, 23 Mar 1997, Laman et al. 994 (BO, L). Unknown location (Kalimantan): de Vriese 141 (L); de Vriese 167 (L).

MALAYSIA: Johor: Alor Bukit, 22 Nov 1966, Hardial Singh 529 (L); Kluang, 5 Mar 1973, Hardial Singh 1095 (L); Kota Tinggi, 21 May 1978, Maxwell 78-242 (L); Kota Tinggi, 21 May 1978, Maxwell 78-246 (L); Kota Tinggi, Ridley 15381 (BM); Kota Tinggi, Kuala Sedili, 23 Jun 1959, Kadim \& Noor, M. 128 (L); Kota Tinggi, Mersing Road, 31 Aug 1977, Maxwell 77397 (L); Kota Tinggi, Mawai Baharu, 22 May 1978, Maxwell 78-276 (L). Kedah: Semeling, Mar 1911, Bell \& Haniff s.n. (K); Sungai Patani, 2 Sep 1938, Wolfe \& Abdul Kadir SFN 21460 (BM, K). Kelantan: Gua Musang, road from Kuala Betis to Kampong How, 12 Oct 1985, Latiff \& Zainudin 1070 (L); Sungei Lebir, Kuala Rantong, 5 Sep 1967, Cockburn KEP 116000 (K); Kampung Parit, 18 Feb 1933, Haniff SFN 10234 (BO); Kuala Aring, 1 Sep 1899, Yapp 126 (K). Malacca: Griffith KD 2271 (K); Maingay KD 786 (L). Pahang: Fraser's Hill, 16 Sep 1922, Burkill \& Holttum SFN 8647 (BO); Fraser's Hill, 1500 m, 29 Sep 1978, Maxwell 78-371 (L); Lubok Temang, 12 Jun 1923, Henderson FMS 11024 (L); Sungai Telom, 1036 m, 23 Oct 1930, Kiah \& Strugnell SFN 23926 (BM); Cameron Highlands, 1200 m, 12 Apr 1937, Nur SFN 32639 (K); Ulu Sungai Kuantan, 213 m, 11 Jun 1934, Symington \& Kiah SFN 28781 (K). Penang: Phillips s.n. (K); Schomburgh s.n. (K); Wallich 4043A (BM, K, M, P); Bukit Penang, 165 m, Curtis 1008 (K); Penara Bukit, 350 m, 3 Jun 1938, Yahya SFN 21444 (K). Perak: King's Collector 10366 (P); Scortechini 64 (P); Scortechini s.n. (L); Maxwell's Hill, Bodden-Kloss s.n. (BM); Maxwell's Hill, 1250 m, 16 Sep 1949, Sinclair \& Kiah SFN 38738 (BM, K); Maxwell's Hill, 22 Nov 1980, Keng et al. 28 (L); Sungei Siput, 11 Sep 1920, Burkill SFN 6327 (BO); Grik, 18 Jun 1924, Burkill SFN 12429 (BO); Sungai Krian, 27 Oct 1938, Spare SFN 36039 (K, P); Gunung Batu Putih, Wray 1221 (BM, K). Selangor: Rantau Panjang, 31 Jul 1914, Boden-Kloss 82 (K); Rantau Panjang, 3 Aug 1914, Boden-Kloss s.n. (K); Sungei Buloh, 17 Jan 1966, Hardial Singh \& Sidek 383 (K, L); Gading, 500 m, 20 Jul 1969, Loh FRI 13386 (K, L); Klang Gates, Jan 1921, Ridley s.n. (K). Terengganu: Gunong Padang, 1200 m, Jun 1937, Moysey \& Kiah SFN 31048 (K); Bundi, 1904, Rostados s.n. (BM, K); Tasik Kenyir, Simpan Tembat, 221 m, 19 Nov 2008, Kamarul Hisham et al. FRI 59335 (L). Sarawak: Bartlett s.n. (BM); Beccari PB 554 (K, P); Beccari PB 776 (K, P); Beccari PB 2024 (P); Native Collector 89 (BM, L, P); Native Collector 549 (BM, L); Native Collector 1459 
(K, P); Native Collector 1793 (BM); Kuching, 11 Apr 1954, Brooke 8329 (BM, L); Kuching, Haviland 145 (BM, L); Kuching, Sakib s.n. (K); Kuching, Mount Penrissen, Haviland 69 (K); Lundu, Biawak, Ulu Sungai Pasir, 9 Apr 1997, Jamree et al. S.76759 (K); Ibid., Samunsan, Sungei Belinsa, 10 Mar 1989, Othman Ismawi et al. S.62272 (K, L); Kuching, Pueh, Sungai Kopak, 200 m, 19 Aug 1996, Rantai Jawa \& Lai S.74519 (L); Kuching, Salampit, 19 Jul 1989, Yahud et al. S.56690 (K, L); Sibu, Naman, 26 Feb 1958, Sanusi S.9765 (K, L).

THAILAND: Krabi: Tambon Khao Panom, 100 m, 30 Mar 1930, Kerr 18780 (BM, K); Nong Khon, 15 Aug 1964, Sangkhachand BKF 46354 (K, L). Nakhon Si Thammarat: Kao Den, 200 m, 14 Apr 1928, Kerr 15308 (BM, K); Kao Soi Dao, 100 m, 29 Apr 1930, Kerr 19235 (BM, K, L). Narathiwat: Nikhom Waeng, 6 Mar 1974, Larsen \& Larsen 33025 (K, P); Sungei Kolok, 7 Sep 1966, Sangkhachand \& Nimanong 1325 (K, L); Ban Bala-Pookaotong, 420 m, 4 Oct 2003, Promchua 64 (L). Phang Nga: Takuapa, Kapong, 75 m, 17 Jul 1972, Larsen et al. 31095 (K, L); Thai Muang, Khao Lumpee Hat Thai Muang, 30 m, 22 Jun 2006, Williams 2045 (K, L). Ranong: Khlong Kam Puan, 100 m, 26 Apr 1973, Geesink \& Santisuk 4955 (K, L, P); Khlong Kam Puan, 100 m, 1 May 1973, Geesink \& Santisuk 5097 (L, P); Khlong Kam Puan, 26 Apr 1974, Larsen \& Larsen 33404 (K, L, P); Muang Leng, 11 Jan 1966, Hansen \& Smitinand BKF 40175 (L). Songkhla: Rattapoom, Boripat Falls, 50 m, 30 Aug 1986, Maxwell 86-644 (L); Khao Luke Lome, 450 m, 16 Sep 1986, Maxwell 86-683 (L). Surat Thani: Panom, 50 m, 25 Mar 1927, Kerr 12420 (BM, K); Panom, 20 Aug 1976, Praphat 65 (K, L, P); Kaw Samui, 31 May 1927, Put 742 (BM, K, L). Trang: Khao Chong, 150 m, 13 Aug 1975, Maxwell 75-810 (L). Yala: Chaung, 24 Jun 1930, Kiah SFN 24378 (K).

Notes. Macrolenes nemorosa is the only species that can easily be recognised by its villous or tomentose indumentum on most parts and by the lack of any bristle hairs. It has a wide distribution, similar to that of Macrolenes pachygyna and M. stellulata, and ranges from Thailand, and Peninsular Malaysia to Sumatra and Borneo; not recorded for Java.

12. Macrolenes pachygyna (Korth.) M.P.Nayar, J. Jap. Bot 55: 49 (1980). - Marumia pachygyna Korth. in Temminck, Verh. Nat. Gesch. Ned. Bezitt., Bot. t. 59 (1842); Blume, Mus. Bot. 1(3): 34 (1849); Naudin, Ann. Sci. Nat., Bot. sér. 3, 15: 281 (1851); Miquel, Fl. Ned. Ind. 1(1): 535 (1855); Triana, Trans. Linn. Soc. London 28(1): 82 (1872); Cogniaux in Boerlage, Handl. Fl. Ned. Ind. 2:532 (1890); Cogniaux in de Candolle \& de Candolle, Monogr. Phan. 7: 552 (1891); Merrill, Univ. Calif. Publ. Bot. 25: 223 (1929); Furtado, Gard. Bull. Singapore 20: 116 (1963). - Dissochaeta pachygyna (Korth.) I.M.Turner, Taxon 67(3): 628 (2018). - TYPE: Indonesia, Borneo, Kapoeas-Barito, Tewe River, P.W. Korthals s.n. (lectotype L [L0008936], first step designated by Bakhuizen van den Brink in Contr. Melastom. 217 (1943); second step designated by Turner in Taxon 67: 628 (2018); isolectotypes K [K000867112], L [L0537218, L0537219], P [P05283680, P05283682, images seen], S [SG-3965, image seen]). (Fig. 12)

Marumia jackii Korth. in Temminck, Verh. Nat. Gesch. Ned. Bezitt., Bot. 243 (1844). - TYPE: Indonesia, West Sumatra, G. Malintang, P.W. Korthals s.n. (lectotype L [L0537214], first step designated by Bakhuizen van den Brink in Contr. Melastom. 217 
(1943); second step designated here; isolectotypes K [K000867113], L [L0008935], P [P05283635, P05283636, images seen]).

Marumia vulcanica Korth. in Temminck, Verh. Nat. Gesch. Ned. Bezitt., Bot. 243 (1844); Blume, Mus. Bot. 1(3): 34 (1849); Naudin, Ann. Sci. Nat., Bot. sér. 3, 15: 282 (1851); Miquel, Fl. Ned. Ind. 1(1): 536 (1855). - TYPE: Indonesia, West Sumatra, G. Merapi, P.W. Korthals s.n. (lectotype L [L0537216], first step designated by Bakhuizen van den Brink in Contr. Melastom. 217 (1943); second step designated by Turner in Taxon 67: 628 (2018); isolectotypes L [L0008934, L0537215], $\mathrm{P}$ [P05283633, image seen]).

Marumia stellulata Korth. in Temminck, Verh. Nat. Gesch. Ned. Bezitt., Bot. 243 (1844), nom. illeg., non Blume (1831). - Marumia reticulata Blume, Mus. Bot. 1(3): 34 (1849); Naudin, Ann. Sci. Nat., Bot. sér. 3, 15: 282 (1851); Miquel, F1. Ned. Ind. 1(1): 535 (1855); Triana, Trans. Linn. Soc. London 28(1): 82 (1872); Clarke in Hooker, Fl. Brit. India 2: 542 (1879); Cogniaux in Boerlage, Handl. F1. Ned. Ind. 2: 532 (1890); Cogniaux in de Candolle \& de Candolle, Monogr. Phan. 7: 551 (1891); King, J. Asiat. Soc. Bengal, Pt. 2, Nat. Hist. 69(1): 49 (1900); Koorders, Exkurs.-Fl. Java 2: 694 (1912); Ridley, F1. Malay Penins. 1: 795 (1922). - Macrolenes reticulata (Blume) Bakh.f., Contr. Melastom. 215 (1943). - TYPE: Indonesia, Sumatra, Indrapoera, Korthals s.n. (lectotype L [L0537217], first step designated by Bakhuizen van den Brink in Contr. Melastom. 216 (1943); second step designated here; isolectotype P [P02274819, image seen]).

Dissochaeta reformata Blume, Mus. Bot. 1(3): 36 (1849); Naudin, Ann. Sci. Nat. Bot. sér. 3, 15: 79 (1851); Miquel, Fl. Ned. Ind. 1(1): 530 (1855); Clausing in Renner et al., Fl. Thailand 7(3): 428 (2001). - Anplectrum reformatum (Blume) Triana, Trans. Linn. Soc. London 28(1): 85 (1872); Cogniaux in de Candolle \& de Candolle, Monogr. Phan. 7: 568 (1891). - Diplectria reformata (Blume) Kuntze, Revis. Gen. P1. 1: 246 (1891). - TYPE: Indonesia, Borneo, Barito, Doesoen, P.W. Korthals s.n. (lectotype L [L0537220], designated by Veldkamp \& Nayar in Blumea 24: 434 (1979 ['1978']); isolectotype L [L0537221]).

Marumia oligantha Naudin, Ann. Sci. Nat., Bot. sér. 3, 15: 281 (1851); Miquel, Fl. Ned. Ind. 1(1): 534 (1855). - TYPE: Indonesia, Sumatra, Lampong, Gunung Logie, 30 Spetember 1845, H. Zollinger 3070 (lectotype P [P02274820, image seen], designated here; isolectotypes BM, BO [BO1751361], G-DC [G00319905, image seen]).

Marumia korthalsiana Miq., F1. Ned. Ind., Eerst. Bijv. 2: 318 (1861); Triana, Trans. Linn. Soc. London 28(1): 82 (1872); Cogniaux in de Candolle \& de Candolle, Monogr. Phan. 7: 553 (1891). - TYPE: Indonesia, West Sumatra, Loeboek Sikaping, Teijsmann HB 820 (lectotype U [U0004055], designated by Bakhuizen van den Brink in Contr. Melastom. 217 (1943); isolectotype BO [BO1764891]). 


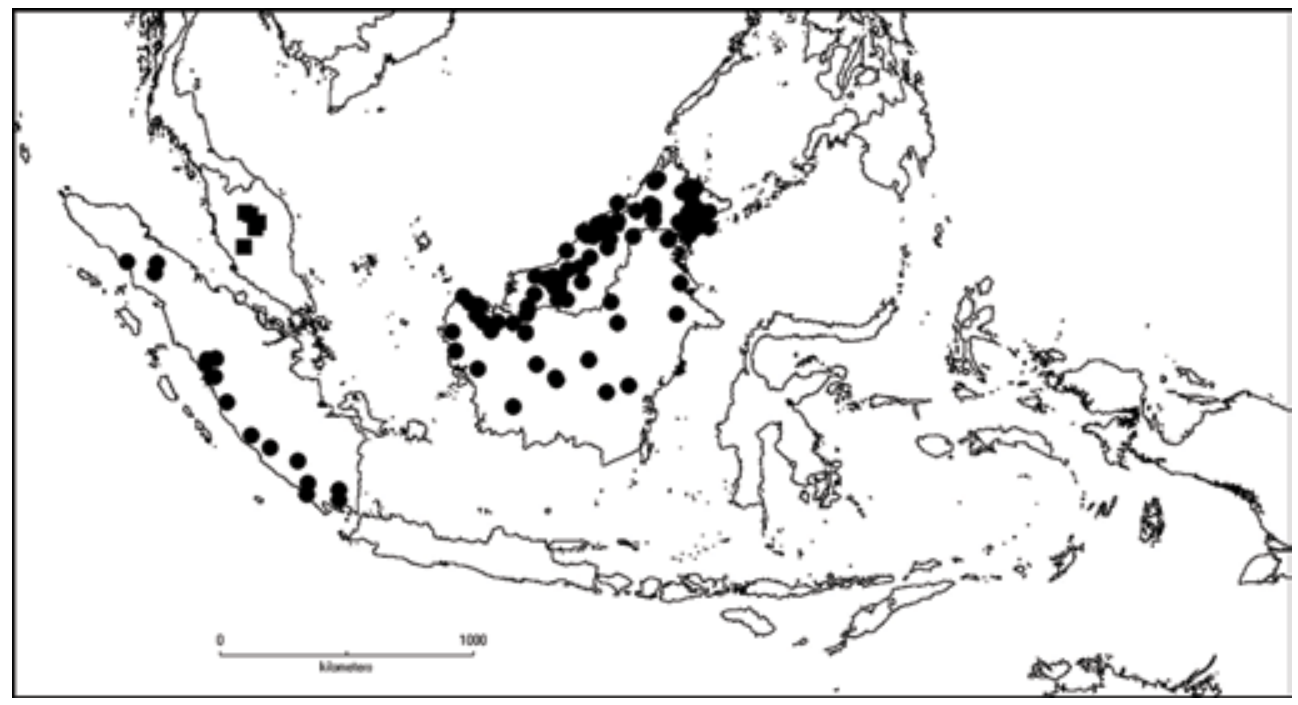

Fig. 12. Distribution of M. pachygyna (Korth.) M.P.Nayar $(\bullet)$ and M. rufolanata (Ridl.) J.F.Maxwell (ם).

Marumia stellulata auct. non. Blume: Naudin, Ann. Sci. Nat., Bot. sér. 3, 15: 282 (1851); Miquel, Fl. Ned. Ind. 1(1): 535 (1855); Triana, Trans. Linn. Soc. London 28(1): 82 (1872); Cogniaux in Boerlage, Handl. Fl. Ned. Ind. 2:532 (1890); Cogniaux in de Candolle \& de Candolle, Monogr. Phan. 7: 552 (1891) (all p.p. excl. type).

Macrolenes stellulata auct. non. (Blume) Bakh.f.: Bakhuizen van den Brink, Contr. Melastom. 216 (1943) (p.p. excl. type).

Climbing up to $15 \mathrm{~m}$ high. Branchlets terete, 3-4.5 $\mathrm{mm}$ in diameter, densely covered with minute brown stellate-furfuraceous hairs, glabrescent at the end; nodes swollen, with a simple interpetiolar ridge, densely stellate-furfuraceous; internodes 5.5-10.5 cm long. Leaves: petioles terete, $8-15 \mathrm{~mm}$ long, densely brown stellate-furfuraceous; blades elliptic, elliptic-oblong to oblong, $8.8-18 \times 3.3-8.7 \mathrm{~cm}$, subcoriaceous, base subcordate, margin entire, apex acuminate, acumen $0.3-1 \mathrm{~cm}$ long, adaxially glabrous, dark glossy green, abaxially densely brown stellate-furfuraceous to tomentose. Inflorescences 5-10 cm long, with 1-12 flowers; main axis angular, densely brown stellate-furfuraceous; primary axis $4-8 \mathrm{~cm}$ long with 1 or 2 nodes, secondary axis 1-2 mm long with 1 node or not developed; bracts linear, 5-6 mm long, not ciliate, stellate-tomentose, caducous; bracteoles lanceolate, linear or subulate, 4-10 $\times 1-2$ $\mathrm{mm}$ long, not ciliate, stellate-tomentose, caducous; pedicels terete, densely stellatefurfuraceous, thickened to $2-3 \mathrm{~mm}$ in diameter, $2-3 \mathrm{~mm}$ long in central and lateral flowers. Hypanthium campanulate to suburceolate, 10-16 $\times 5-9 \mathrm{~mm}$, brownish when dry, densely covered with brown stellate-furfuraceous hairs and 2-3 $\mathrm{mm}$ long bristles barbed or branched at tip, completely covered with minute brown stellate hairs; calyx 
lobes triangular, 4-7 × 3-5 mm, tips acute, densely covered with minute stellatefurfuraceous hairs, margin ciliate, bristles with simple or branched tip and covered with minute brown stellate hairs. Petals in bud conical, 5-13 mm long, apex acute, stellate-furfuraceous; mature petals obovate to suborbicular, 10-25 × 7-15 mm, reflexed, base clawed, apex obtuse, above glabrous, underneath half stellatefurfuraceous and half glabrous, white. Stamens: alternipetalous stamens with 13-15 $\mathrm{mm}$ long filaments, anthers curved, sickle-shaped, thecae 15-17 mm long, apex rostrate, pedoconnective c. $9 \mathrm{~mm}$ long, connective basal crest lamellar and annular, prolonged into several fimbriate, filiform appendages, 9-10 $\mathrm{mm}$ long, laterally with paired, filiform appendages, 9-10 mm long; oppositipetalous stamens with 8-12 mm long filaments, anthers S-shaped, 13-15 mm long, connective with a thin keel crest, up to $3 \mathrm{~mm}$ long, basally with paired, filiform lateral appendages, 7-11 $\mathrm{mm}$ long. Ovary $2 / 3$ as long as hypanthium, apex densely covered with capitate bristle hairs and smooth brown hairs; style 20-30 mm long, curved at tip, white, upper part glabrous, base densely covered with brown hairs; stigma minute, capitate; extra-ovarial chambers extending to near base of ovary. Fruits ovoid or urceolate, 10-15 $\times 6-12 \mathrm{~mm}$, sparsely covered with stellate hairs and densely covered with branched- or barbed-tip bristle hairs, apex densely covered with capitate bristle hairs and smooth brown hairs; calyx lobe remnants persistent, reflexed. Seeds c. $0.75 \mathrm{~mm}$ long.

Distribution. Sumatra and Borneo.

Habitat \& ecology. Primary or secondary lowland dipterocarp forest, lower montane forest, swamp forest, riverine or heath forest, in open or logged places; 10-1180 m elevation.

Vernacular names. Sumatra: kangon sipuan (Sungei), sikaduduk rimbo (Minang). Borneo: letah letah (Murut), radi akar (Sanggau).

Additional specimens examined. BRUNEI: Belait: Kuala Ingei, 30 m, 7 Jul 1957, Ashton BRUN 152 (BO, K, L); Sungei Belait, 3 Nov 1989, Forman \& Blewett 1194 (K, L); Labi, 17 Feb 1969, van Niel 4585 (L); Labi, Malayan Ulu, 2 Aug 1997, Ogata et al. 527 (L); Sungai Rampayoh, 9 Jan 1994, Kirkup \& Coode 795 (L); Bukit Puan, 29 Aug 1960, Sinclair \& Kadim 10484 (K, L); Melilas, 100 m, 24 Nov 1992, Thomas et al. 109 (K, L); Bukit Sawat, 10 Apr 1997, Ogata et al. 464 (L). Temburong: Sungai Belalong, 50 m, 17 Feb 1991, Argent et al. 916 (K, L); Batu Apoi, Selapon, Bukit Belitun, 100 m, 29 Jan 1994, Coode et al. 7940 (L). Tutong: Panchong-Benutang, 10 m, 21 Oct 1989, Forman \& Blewett 994 (K, L); Ulu Tutong, Ramba, 150 m, 11 May 1992, Johns et al. 7625 (K).

INDONESIA: Aceh: Mount Leuser National Park, Klut Nature Reserve, Pucuk Lembang, 40 m, 8 Jul 1985, de Wilde \& de Wilde-Duyfjes 19809 (BO, L). Bengkulu: Lebong Tandai, Jul 1922, Brooks 7922 (K); Bukit Kaba, 800 m, 29 Mar 1922, de Voogd 1372 (BO). Lampung: Sep 1845, Zollinger 778 (P); Krui, Sukau, 28 Jan 1924, Bouman-Houtman 11 (BO). North Sumatra: Sidikalang, road Sidikalang-Pongkolan, 1200 m, 27 Mar 1954, Alston 14794 (BM, L); Lau Lintang, Gunung Rinte, 280 m, Lörzing 16323 (BO, L). South Sumatra: Forbes 2783 (BM, L, P); Ranau Lake, 700 m, 7 Nov 1929, De Voogd 426 (BO). West Sumatra: 
Mount Singgalang, Jul 1878, Beccari PS 109 (BM, K, L); Mount Talang, 1550 m, 20 Oct 1918, Bünnemeijer 5180 (BO); Pariaman, Bukit Tambun Tulang, 450 m, 28 Mar 1987, Den 9 (ANDA); Payakumbuh, Mount Sago, 900 m, 9 Jun 1955, Meijer 3421 (BO); Lubuk Paraku, 500 m, 17 Sep 1988, Nagamasu 3311 (ANDA). Central Kalimantan: Nanga Bulik, Sungai Buluh, 300 m, 29 Feb 1984, Hansen 1233 (BO, L); Nanga Bulik, Sungai Lamandau, 50 m, 12 Mar 1984, Hansen 1270 (BO); Nanga Bulik, Sungai Lamandau, 50 m, 12 Mar 1984, Hansen 1283 (BO, L); Katingan River, Tumbang Samba, 235 m, 19 Jan 1995, Jarvie \& Ruskandi 5014 (BO, L); Katingan River, Tumbang Samba, 200 m, 22 Dec 1982, Mogea \& de Wilde (BO, K, L); Katingan River, Tumbang Samba, 100 m, 5 Feb 1983, Wiriadinata 3548 (BO, L). East Kalimantan: West Kutai, Hikam Batu Beng, 50 m, 26 Jul 1925, Endert 2248 (BO, K, L); West Kutai, Hikam Batu Beng, 50 m, 29 Jul 1925, Endert 2293 (BO, K, L); West Kutai, Hikam Batu Beng, 15 Oct 1925, Endert 4173 (BO, L); Sungei Doho, Jaheri 1591 (BO); Tanjung Redeb, Birang River, 10 m, Kessler Berau-317 (L); Berau, Mount Ilas Bungaan, 300 m, 9 Sep 1957, Kostermans 13747 (BO, K, L); Mului, 414 m, 1 Dec 2005, Raes et al 717 (K, L). North Kalimantan: Krayan, Long Bawan, Gunung Batu Linanit, 1100 m, 31 Jul 1981, Kato et al. B-10295 (BO, L); Sebatik Island, 28 Dec 1954, Kostermans 10711 (BO, L); Nunukan, Sungai Semboyong, Nov 1953, Meijer 2193 (BO, K, L); Ibid., Sungai Simengkadu, Dec 1953, Meijer 2361 (BO, K, L). West Kalimantan: Sintang, 150 m, 10 Apr 1994, Church 816 (BO, K, L); Sintang, Ketungau Tengah, Nanga Kelapan, 150 m, 15 Apr 2014, Kartonegoro \& Pratama 777 (BO); Smitauw, Hallier 1361 (BO, K, L, P); Sungai Kenepai, Hallier 1971 (BO); Gunung Melawi, Teijsmann HB 8659 (BO); Sungai Landak, Teijsmann s.n. (BO); Sanggau, Noyan, Ngira, 14 Oct 1993, de Jong 552 (L).

MALAYSIA: Sabah: Kalabakan, Luasong, 22 Sep 1980, Fidilis \& Sumbing SAN 91872 (K, L); Kalabakan, Luasong, 26 Apr 1982, Fidilis SAN 94793 (K, L); Kalabakan, Luasong, 23 Feb 1982, Fidilis \& Sumbing SAN 95684 (L); Kalabakan, Luasong, 190 m, 20 Jul 2001, Postar et al. SAN 144073 (K, L); Kalabakan, Sapulut, Labang, 25 Oct 1988, Fidilis \& Sawan SAN 125276 (K, L); Kalabakan, Brantian, 6 Apr 1972, Kumin SAN 75321 (K, L); Kinabatangan, Bukit Garam, 20 Feb 1987, George et al. SAN 117562 (K); Kinabatangan, Sungai Mananggul, 28 Jan 1988, Joseph et al. SAN 123830 (K, L); Lamag, Ulu Sungai Pin, 8 Sep 1979, Leopold \& Petrus SAN 90978 (K, L); Keningau, Mandalom, 21 Feb 1989, Sawan SAN 125399 (K, L); Lahad Datu, Silam, 11 Jan 1966, Ahmad Talip SAN 52942 (K, L); Lahad Datu, Danum Valley, Ulu Segama, 200 m, 28 Feb 1985, Argent et al. 108275 (K); Lahad Datu, Danum Valley, Ulu Segama, 16 Mar 1988, George et al. SAN 123927 (K); Lahad Datu, Danum Valley, Ulu Segama, 30 Jun 2006, Karolus 66 (K); Ibid., 14 May 1989, Ridsdale 2022 (K, L); Ibid., 16 Mar 2008, Ridsdale SAN 148778 (K); Lahad Datu, Silabukan, 230 m, 18 Feb 1963, Sitiol SAN 33427 (K, L); Lahad Datu, Ulu Tabin, 750 m, 15 Jan 1990, Dewol SAN 129537 (K, L); Kaboy River, 15 m, 17 Nov 1932, Burot 2690 (BO, K, L); Nabawan, Witti Range, Tiulon, 800 m, 11 Mar 1982, Dewol SAN 94956 (L); Nabawan, Nabawan-Pandawan Road, 17 Mar 1990, Sumbing Jimpin SAN 128479 (L); Ranau, Mount Kinabalu, Mount Nunkok, 900 m, 31 May 1933, Clemens \& Clemens 32765 (BM, BO, K, L, M); Ranau, Mount Kinabalu, Penibukan, 1200 m, 2 Nov 1933, Clemens \& Clemens 50066 (K, L); Ranau, Mount Kinabalu, Penokok, 1200 m, Haviland 1345 (K); Sandakan, Kabili-Sepilok, 100 m, 1 May 1935, Castro 4502 (K); Ibid., 9 Apr 1954, Wood A1963 (K, L); Sandakan, Elmer 20241 (BM, BO, K, L, M, P, PNH, U); Sandakan, Ramos BS 1211 (BO, K); Sandakan, Segaliud Lokan, 15 Jan 1975, Aban Gibot SAN 81124 (L); Sandakan, Segaliud Lokan, 7 Mar 1975, Leopold \& Kodoh SAN 81380 (K, L); Sandakan, Segaliud Lokan, 11 Mar 1975, Leopold \& Kodoh SAN 81430 (K, L); Sandakan, Segaliud Lokan, 8 Oct 1988, Majawat et al. SAN 102411 (K); Sandakan, Elopura, 18 Nov 1947, Cuadra A1118 (BO, K); Sandakan, Telupid, 60 m, 19 May 1978, Dewol SAN 79466 (K, L); Sandakan, Tanjung Batu, 
10 m, 25 Mar 1948, Anthony A774 (K); Sandakan, Sungai Menuil, 17 m, 15 Mar 1963, Sayu Elleh SAN 35426 (K, L); Tawau, Elmer 20548 (BM, BO, K, L, M, P, U); Tawau, Elmer 21540 (BM, BO, K, L, M, P, U); Tawau, Merotai Kecil, 45 m, 28 Dec 1963, Aban Gibot SAN 18610 (K); Ibid., Balung River, 170 m, 17 Jul 1963, Aban Gibot SAN 36998 (K, L). Sarawak: Barber 313 (K); Brooks 1024 (BM); Balingian, Bawan, 10 m, 20 Oct 1963, Chai S.19479 (BO, K, L); Baram, Dec 1894, Hose 228 (BM, K); Baram, Anap, 700 m, 8 Sep 1964, Sibat ak Luang S.21991 (K, L); Baram, Bukit Mersing, 1300 m, 1 Jun 1956, Purseglove 5260 (K, L); Baram, Sungai Tau, 60 m, 28 May 1956, Purseglove 5112 (K, L); Baram, Ulu Tinjar, Mount Dulit, 1000 m, 29 Aug 1932, Richards 1520 (K); Belaga, Ulu Belaga, Sepakau Logging Camp, 250 m, 13 Oct 1981, Hansen 601 (L); Belaga, Batang Balui, Batu Laga, 600 m, 6 Mar 1989, Yii S.56517 (K, L); Belaga, 30 Mar 1989, Yii S. 62379 (K, L); Bintulu, Nanga Sapulow, 50 m, 5 Jul 1966, Ding Hou 465 (BO, K, L); Bintulu, Similaujan FR., 100 m, 3 Sep 1991, Frodin 2180 (L); Bintulu, Tatau, Bukit Kana, 500 m, 24 Mar 1995, 24 Mar 1995, Yii \& Jugah ak Kudi S. 71623 (L); Kapit, Bukit Tibang, 1300 m, 9 Jul 1969, Anderson \& Paie S. 28604 (K, L); Kapit, Rejang, Pelagus, 18 Apr 1963, Ashton S. 18298 (BO, K, L); Kapit, Balleh, Menyiong, 500 m, 12 Nov 1979, Othman et al. S.41366 (K, L); Kuching, Beccari PB 1022 (BM, K, M, P); Kuching, Beccari PB 2311 (K); Kuching, Beccari PB 2355 (P); Kuching, Bau, 60 m, 15 Dec 1965, Chai \& Seng S.16198 (K, L); Kuching, Kubah, 85 m, 17 Sep 1994, Rantai Jawa et al. S.68453 (K, L); Kuching, Matang, 21 Jan 1894, Haviland 146 (BM, BO, K); Kuching, Matang, 300 m, 25 Oct 1929, Clemens \& Clemens 20933 (K); Kuching, Matang, Gibbs 4424 (BM); Kuching, Matang, 20 m, 7 Jan 1964, Chai S. 19757 (BO, K, L); Kuching, Gunung Gading, 988 m, 4 May 2007, Sabran et al. S.83747 (K); Lubok Antu, Sungai Engkari, 21 Mar 1974, Chai S.34081 (K, L); Miri, Bakam Road, 3 Apr 1966, Sibat ak Luang S. 24739 (BO, K, L); Miri, Bakam Road, 7 Apr 1966, Benang ak Bubong S.24838 (BO, K, L); Lundu, Ulu Sungai Samunsam, 27 Mar 1989, Othman Ismawi et al. S. 56634 (AAU, L); Miri, Gunung Mulu, 29 Jul 1977, Chai S.39573 (K, L); Miri, Lambir Hill, 50 m, 6 Jul 1962, Paie S.16609 (BO, K, L); Miri, Lambir Hill, 22 Oct 1983, Abang Mochtar S.47117 (K, L); Miri, Lambir Hill, 4 Mar 1966, Awang S.24114 (BO, K, L); Miri, Sungai Bakong, 80 m, 26 Feb 1966, Sibat ak Luang S.24453 (BO, K, L); Miri, Ulu Luak, 50 m, Othman S.21311 (K, L); Mukah, Mukah Hill, 13 Jul 1997, Stephen et al. S.77357 (AAU, K, L); Sarikei, Lanjak Entimau, Sungai Merinum, 280 m, 1 Nov 1998, Julaihi \& Jamree S.79209 (K, L); Serian, Tebedu, 26 Jun 1996, Jamree et al. S. 73760 (K); Sibu, Gat, Mount Majau, 25 Jul 1929, Clemens \& Clemens 21594 (BO, K); Simunjan, Sabal, 400 m, 25 Feb 1995, Runi et al. S.71293 (L); Mount Sengghai, 370 m, 30 Dec 1927, Native Collector 5153 (BO); Marudi, 300 m, Feb 1932, Richards 2661 (K, L); Kampong Liam, 5 Nov 1976, Yeo \& Jugah ak Kudi S.38400 (K, L).

Notes. The species has conspicuous bristle hairs with a branched or barbed tip and it is covered with minute stellate hairs from base to apex. Bristle hairs on Macrolenes hirsuta and $M$. veldkampii are also barbed at the tip, but only covered by minute stellate hairs in the upper part, while the base is glabrous. The other species with barbed-tip bristle hairs is Macrolenes stellulata that differs in rather puberulous leaves and distinct, ovate-lanceolate bracts and bracteoles.

Naudin (1851) erroneously wrote that the type of Macrolenes oligantha (Zollinger 3070) was collected on Java, but the label indicates that it was collected on Gunung Logie ('Gunung Sugih'), Lampung, Sumatra. The latter is more likely as no other specimens from Java are known. Only Macrolenes annulata and M. muscosa are known from Java. 
Nayar (1980) correctly took this species out of the synonymy of Macrolenes stellulata (Jack) Bakh.f. Macrolenes pachygyna has elliptic-oblong leaves and linear bracts and bracteoles, while $M$. stellulata has oblong-ovate leaves and laciniate leaf-like bracts and bracteoles.

The basionym of the species (Marumia pachygyna) was validly published by Korthals with illustration plate earlier in 1842 and followed by the full description in 1844 (Turner, 2018).

13. Macrolenes rufolanata (Ridl.) J.F.Maxwell, Gard. Bull. Singapore 33: 321 (1980). - Marumia rufolanata Ridl., Fl. Malay Penins. 5: 310 (1925). - TYPE: Malaysia, Peninsular Malaysia, Pahang, Kuala Lipis, Ulu Chimeras, $200 \mathrm{ft}$ alt., 18 November 1924, I.H. Burkill \& Haniff SFN 15661 (lectotype K [K000867119], designated here; isolectotype SING [SING0052046; SING0052047]). (Fig. 12)

Branchlets terete, 4-6 $\mathrm{mm}$ in diameter, densely tomentose, covered with minute brown stellate-furfuraceous hairs; nodes swollen, with interpetiolar ridge; internodes 6-10 cm long. Leaves: petioles terete, 10-12 mm long, densely brown stellatefurfuraceous; blades elliptic to elliptic-oblong, 7.5-12 ×3-6 cm, subcoriaceous, base subcordate, margin entire, apex acuminate, acumen c. $5 \mathrm{~mm}$ long, adaxially glabrous, dark glossy green, abaxially densely brown stellate-tomentose. Inflorescences 8-15 cm long, with 3-10 flowers; main axis terete, densely brown stellate-furfuraceous; primary axis 5-10 cm long with 2 or 3 nodes, secondary axis $1.5-2 \mathrm{~cm}$ long with 1 node, tertiary axis not developed or up to $5 \mathrm{~mm}$ long; bracts ovate, $6-7 \times 4-5 \mathrm{~mm}$, densely stellate-tomentose with simple bristle hairs on margin, caducous; bracteoles ovate, $2-3 \times$ c. $2 \mathrm{~mm}$, densely brown stellate-tomentose with simple bristle hairs on margin, caducous; pedicels densely brown stellate-tomentose, 2-3 mm long in central flowers, c. $1 \mathrm{~mm}$ long or almost absent in lateral flowers. Hypanthium campanulate, 10-12 × 6-7 mm, densely covered with minute brown stellate-furfuraceous hairs and 1-1.5 mm long simple, thick, bristles, densely covered with brown minute stellate hairs, appearing to be capitate; calyx lobes triangular with acute tips, $5-7 \times$ c. $3 \mathrm{~mm}$, densely covered with minute brown stellate hairs, outer surface also covered with c. 1 $\mathrm{mm}$ long bristle hairs densely covered with brown stellate hairs, inner surface lacking bristle hairs, margin without bristle hairs, not ciliate. Petals in bud and when mature not seen, ovate, apparently white, centre of abaxial surface scurfy (see Ridley, 1925). Stamens: alternipetalous stamens (in bud) with 10-12 $\mathrm{mm}$ long white filaments, anthers straight, thecae 10-11 mm long, apex rostrate, pedoconnective c. $4 \mathrm{~mm}$ long, connective basal crest thin, annular, with several fimbriate, filiform appendages, 4-6 $\mathrm{mm}$ long, lateral appendages paired, filiform, 4-5 mm long; oppositipetalous stamens with c. $10 \mathrm{~mm}$ long white filaments, anthers straight, thecae 8-10 $\mathrm{mm}$ long, connective with a thin keel crest, up to $2 \mathrm{~mm}$ long, lateral appendages paired, filiform, 5-6 mm long. Ovary $2 / 3$ as long as hypanthium, apex villous; style 10-12 mm long, glabrous, villous near base; stigma minute; extra-ovarial chambers extending almost to base of ovary. Fruits ovoid to suburceolate, 10-15 × 7-9 mm, brown, densely covered with 
minute brown stellate-furfuraceous hairs and 1-1.5 $\mathrm{mm}$ long simple, thick bristles densely covered with brown minute stellate hairs; calyx lobe remnants persistent, reflexed. Seeds c. $0.75 \mathrm{~mm}$ long.

Distribution. Peninsular Malaysia.

Habitat \& ecology. Lowland forest, in open places at 60-90 m elevation.

Vernacular Name. Akar sendudo (Kelantan).

Additional specimens examined. MALAYSIA: Kelantan: Ulu Sungai Kelantan, Sungai Jenal, 25 Oct 1967, Cockburn FRI 7417 (L); Sungei Lebir, Bukit Batu Papan, 120 m, 4 Jul 1936, Henderson SFN 29504 (K). Pahang: Gunong Tahan, 22 Jul 1936, Kiah SFN 31760 (K). Selangor: Fraser's Hill, 1160 m, 25 Apr 1966, Stone 6283 (L).

Notes. Furtado (1963) reduced Macrolenes rufolanata to synonymy of $M$. stelullata because he supposed that the flowers in their young stage of development, with unbranched bristle hairs, would ultimately produce bristle hairs that branch at the apex when mature. However, the holotype $(S F N 15661)$ in Kew has mature flowers and all bristles are neither branched nor barbed at the apex.

14. Macrolenes stellulata (Jack) Bakh.f., Contr. Melastom. 216 (1943). - Melastoma stellulatum Jack, Trans. Linn. Soc. London 14: 6 (1823) "stellulata"; de Candolle, Prodr. 3: 148 (1828). - Marumia stellulata (Jack) Blume, Flora 14: 503 (1831); Naudin, Ann. Sci. Nat., Bot. sér. 3, 15: 282 (1851); Miquel, Fl. Ned. Ind. 1(1): 535 (1855); Triana, Trans. Linn. Soc. London 28(1): 82 (1872); Cogniaux in Boerlage, Handl. F1. Ned. Ind. 2:532 (1890); Cogniaux in de Candolle \& de Candolle, Monogr. Phan. 7: 552 (1891). - TYPE: Indonesia, Sumatra, Bencoelen, Saloomah, Jack s.n. (lost); Indonesia, Sumatra, Jambi Province, Harapan Rain Forest, Nawai River, Kapas River branch, 70 m alt., 8 April 2013, Deden et al. BOHK 239 (neotype BO, designated here; isoneotypes K [K000812315], KEP n.v.). (Fig. 13)

Marumia ciliatiloba Baker f., J. Bot. 62 (Suppl.): 40 (1924); Furtado, Gard. Bull. Singapore 20: 115 (1963). -Macrolenes ciliatiloba (Baker f.) Bakh.f., Contr. Melastom. 215 (1943). - Macrolenes stellulata (Jack) Bakh.f. var. ciliatiloba (Baker f.) J.F.Maxwell, Gard. Bull. Singapore 33: 321 (1980). - TYPE: Indonesia, Sumatra, Res. Palembang, Soekaradja, Roepit River, $600 \mathrm{ft}$ alt., H.O. Forbes 3008 (lectotype BM [BM000944489], designated here; isolectotypes K [K000867111], L [L0008933, L0537222]).

Macrolenes submembranacea Bakh.f., Contr. Melastom. 214 (1943). - TYPE: Indonesia, Sumatra, Res. Bencoelen, G. Raja, Lake Ranau, 1300 m elev., 2 November 1929, C.G.G.J. van Steenis 3522 (holotype L [L0537196]; isotypes BO [BO1751371, BO1751372], SING [SING0052048]). 


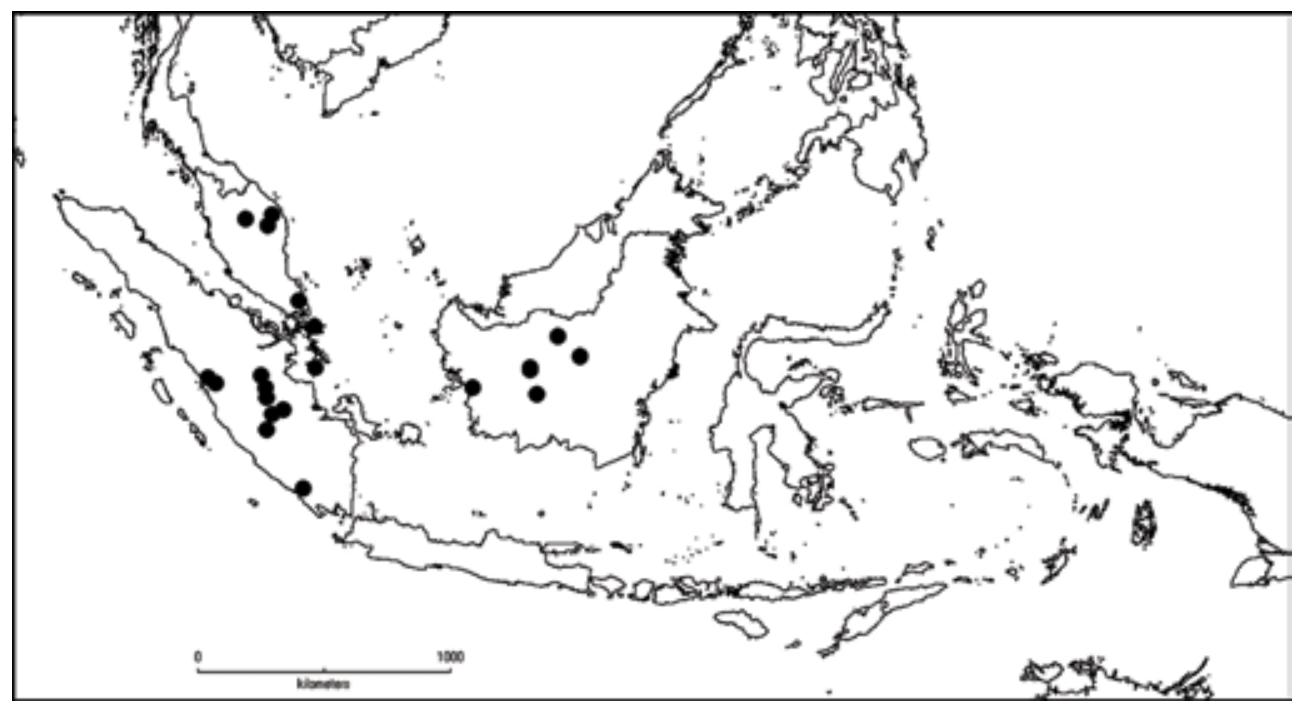

Fig. 13. Distribution of M. stellulata (Jack) Bakh.f. (•).

Climbing up to $15 \mathrm{~m}$ high. Branchlets terete, 3-4 $\mathrm{mm}$ in diameter, covered with minute brown stellate-furfuraceous hairs; nodes swollen, with an annular, crest-like interpetiolar ridge; internodes 5-7 cm long. Leaves: petioles terete or flattened, 10-15 $\mathrm{mm}$ long, densely stellate-tomentose; blades ovate-elliptic to elliptic, 9-14 × 4.7-6 $\mathrm{cm}$, subcoriaceous, base subcordate to cordate with 5-7 $\mathrm{mm}$ long sinuses, margin entire, apex acuminate, acumen $0.5-1 \mathrm{~cm}$ long, adaxially glabrous, abaxially brown stellate-puberulous. Inflorescences 10-15 cm long, with 3-15 flowers; main axis angular, stellate-tomentose; primary axis 5-9 $\mathrm{cm}$ long with 1 or 2 nodes, secondary axis 1.5-3 cm long with 1 node, tertiary axis not developed; bracts ovate, $10-12 \times$ c. $8 \mathrm{~mm}$, stellate-tomentose, margin ciliate, purplish, persistent; bracteoles ovate or suborbicular, 6-7 × 5-6 mm, stellate-tomentose, margin ciliate, purplish; pedicels stellate-tomentose and covered with scattered simple bristle hairs, 2-3 mm long in central flowers, 1-2 mm long in lateral flowers. Hypanthium tubular, 12-21 $\times 5-9$ $\mathrm{mm}$, greyish when dry, densely covered with minute stellate-tomentum and 3-4 mm long bristles with barbed or branched tip, completely covered with dense minute greyish-brown stellate-tomentose hairs; calyx lobes triangular or oblong with truncate base with acute tip, 6-9 $\times 3-4 \mathrm{~mm}$, margin ciliate with simple or barbed-tip bristle hairs and densely covered with minute greyish-brown stellate hairs, densely stellatetomentose, purplish. Petals in bud conical, 9-14 mm long, covered with stellatefurfuraceous hairs; mature petals obovate to suborbicular, 20-22 × 15-18 mm, reflexed, base clawed, apex obtuse, above glabrous, underneath half stellatefurfuraceous, half glabrous, white or purple. Stamens: alternipetalous stamens with 15-16 mm long yellow filaments, anthers slender, curved, sickle-shaped, thecae 24-26 $\mathrm{mm}$ long, yellow, apex rostrate, pedoconnective 7-8 $\mathrm{mm}$ long, connective basal crest thin, annular, prolonged into several fimbriate, filiform appendages, 8-10 mm long, 
pointing sidewards, lateral appendages not developed; oppositipetalous stamens with 13-14 mm long yellow filaments, anthers S-shaped, thecae 18-20 mm long, yellow, connective with a minute thin keel crest or short hairs, basally with ligular appendages prolonged into a single or a pair of filiform, $9-10 \mathrm{~mm}$ long appendages. Ovary $2 / 3$ as long as hypanthium, apex villous and with several 2-3 mm long capitate bristle hairs; style 24-26 mm long, curved at tip, glabrous, stellate-furfuraceous at base; stigma minute, capitate; extra-ovarial chambers extending almost to base of ovary. Fruits urceolate, c. $20 \times 10-12 \mathrm{~mm}$, densely covered with minute stellate-tomentose hairs and 3-4 $\mathrm{mm}$ long bristles with barbed or branched tips, covered by dense minute greyish-brown stellate hairs, apex densely with several capitate bristle hairs; calyx lobe remnants persistent, not reflexed. Seeds c. $0.75 \mathrm{~mm}$ long.

Distribution. Peninsular Malaysia, Sumatra and Borneo.

Habitat \& ecology. Lowland secondary forest and dipterocarp forest, in open places or along roadsides; 30-310 m elevation.

Vernacular name. Peninsular Malaysia: Akar sundok (Malay); Sumatra: daduruh akar (Bengkulu); kidaru (Sukaraja); kedudu akar (Jambi).

Additional specimens examined. INDONESIA: Jambi: 200 m, Sep 1925, Posthumus 927 (BO, L); Sungai Lesing, Oct 1925, Posthumus 989 (BO); Teluk Rendah, 250 m, 20 Aug 1983, Rahayu 324 (BO, L); Harapan Rain Forest, 70 m, 3 Apr 2008, Siahaan 3 (K). Riau: Rengat, Bukit Tiga Puluh Nat. Park, Bukit Karampal, 100 m, 14 Nov 1988, Burley \& Tukirin et al. 1449 (BO, K, L). Riau Archipelago: Singkep Island, Manggu, 40 m, 2 Aug 1919, Bünnemeijer 7170 (BO, K, L); Singkep Island, Manggu, 40 m, 2 Aug 1919, Bünnemeijer 7187 (BO, L); Bintan Island, Bukit Sipinjang, Teijsmann s.n. (BO, L). West Sumatra: Solok, Tabek, Talang Babungo, 1100 m, 26 May 2001, Coco et al. 27 (ANDA); Solok, Tabek, Talang Babungo, 1100 m, 26 May 2001, Ivon et al. 18 (ANDA). Central Kalimantan: Barito Ulu, Joloi River, 15 Jun 1990, Ridsdale PBU 554 (K, L); Kotawaringin Timur, Sangai, 100 m, 27 Sep 1996, Argent et al. 9635 (L). West Kalimantan: Ketapang, Gunung Palung, 30 m, 22 Jun 1986, van Balgooy \& van Setten 5561 (BO, L); Ketapang, Gunung Palung, Cabang Panti, 20 m, 21 Oct 1996, Laman et al. 56 (BO, K, L); Sintang, Bukit Baka, 310 m, 9 Nov 1993, Church et al. 633 (BO, K, L); Liang Gagang, Hallier 3022 (BO, L); Sintang, 25 Jun 1894, Langlasse 95 (P).

MALAYSIA: Johor: Mersing Road, 30 m, 4 Jan 1966, Burkill 3900 (L). Kelantan: Relai, 22 Oct 1967, Cockburn FRI 7298 (K, L). Pahang: Kuala Aur, Ulu Sungai Sepia, 40 m, 16 Jul 1970, Shah \& Noor 1922 (L). Terengganu: Ulu Brang, 120 m, Jul 1937, Moysey \& Kiah SFN 33835 (L).

Notes. Macrolenes pachygyna was considered to be a synonym of $M$. stellulata by Bakhuizen van den Brink (1943) based on the barbed tip of the bristle hairs on the hypanthium but is considered to be a distinct taxon in this revision.

In the description of this species, Jack (1823) wrote that the leaves are oblong-ovate with a cordate base and the bracts are leaf-like, while in Macrolenes pachygyna the leaves are rather elliptic-oblong with a rounded base and the bracts are linear, not-leaf-like. 
The type specimens of Melastoma stellulatum were collected from Sumatra but were lost during shipment to Europe. Therefore, a neotype is choosen in this revision.

Maxwell (1980b) considered Macrolenes ciliatiloba to be a variety of $M$. stelullata sensu Bakh.f., which is actually $M$. pachygyna with its branched or barbed-tip of the bristle hairs on the hypanthium. The bristles in Macrolenes stellulata are rather densely covered with minute greyish-brown stellate hairs and the leaf underneath is puberulous, not tomentose. Bracts and bracteoles on both species are also different, ovate or suborbicular or leaf-like with a laciniate margin in Macrolenes stellulata, linear or lanceolate and lacking a laciniate margin in M. pachygyna.

15. Macrolenes subulata J.F.Maxwell, Gard. Bull Singapore 33: 321, fig. 6 (1980). TYPE: Indonesia, Sumatra, Lampung Province, Mt. Tanggamus, 1100-1200 m alt., 25 April 1968, M. Jacobs 8028 (holotype L [L0537194]; isotypes BO [BO1865976], K [K000867110], KEP [KEP110313, image seen], SING [SING0052049]). (Fig. 14-15)

Climbing up to $2 \mathrm{~m}$ high. Branchlets terete, 3-4 $\mathrm{mm}$ in diameter, densely covered with brown stellate-furfuraceous hairs and often with scattered bristle hairs covered by stellate hairs at the tip; nodes swollen, with interpetiolar ridge; internodes 4-5.5 cm long. Leaves: petioles terete, 6-8 mm long, densely brown stellate-furfuraceous and with scattered bristle hairs covered by stellate hairs at the tip; blades ovate to ovate-elliptic, 7.7-9.5 × 3.2-5 cm, membranous, base shallowly cordate, margin entire, apex acuminate, acumen $0.5-1 \mathrm{~cm}$ long, adaxially glabrous, dark green, abaxially sparsely covered with brown stellate hairs, densely so on veins. Inflorescences 5-7 cm long, with 1-3 flowers; main axis angular, densely brown stellate-furfuraceous and with scattered bristle hairs covered by stellate hairs at the tip; primary axis $2.5-4 \mathrm{~cm}$ long with 1 node, secondary axis not developed; bracts lanceolate, 10-12 × 3-5 mm, brown stellate-furfuraceous; bracteoles lanceolate, 6-10 $\times 3-5 \mathrm{~mm}$, densely stellate-furfuraceous; pedicels densely covered with minute brown stellate-furfuraceous hairs and bristle hairs covered by stellate hairs at the tip, c. $4 \mathrm{~mm}$ long in central flowers, 1-2 mm long in lateral flowers. Hypanthium campanulatetubular, 10-12 × 6-7 mm, densely covered with minute brown stellate-furfuraceous hairs and with 1-3 mm long, thick, simple bristle hairs covered by stellate hairs at the tip; calyx lobes slightly triangular, 9-11 × 4-6 mm, densely brown stellate-tomentose, apex acute, margin with short thick bristle hairs. Petals in bud conical, 5-6 mm long, glabrous; mature petals obovate or suborbicular, 25-30 × 20-25 mm, not reflexed, base clawed, apex obtuse, glabrous, white with purple tinge. Stamens: alternipetalous stamens with 14-15 mm long bright yellow filaments, anthers slender, sickle-shaped, thecae 23-25 mm long, pink, pedoconnective 6-7 $\mathrm{mm}$ long, whitish, connective basal crest small with several fimbriate, filiform appendages, 5-6 $\mathrm{mm}$ long, lateral appendages paired, filiform, 7-8 mm long; oppositipetalous stamens with 12-14 $\mathrm{mm}$ long bright yellow filaments, anthers S-shaped, thick, thecae 16-18 mm long, connective with a pair of ridges or keels, c. $1 \mathrm{~mm}$ long, basally with paired, filiform 
lateral appendages, $6-8 \mathrm{~mm}$ long. Ovary $2 / 3$ as long as hypanthium, apex villous; style 20-22 mm long, curved at apex, glabrous, dark pink, white at apex; stigma minute, capitate; extra-ovarial chambers extending from the middle to base of ovary. Fruits seen immature, c. $12 \times 6-7 \mathrm{~mm}$, densely covered with brown minute stellatefurfuraceous hairs and $1-3 \mathrm{~mm}$ long, thick, bristle hairs covered by stellate hairs at the tip; calyx lobes persistent, reflexed. Seeds seen immature, c. $0.4 \mathrm{~mm}$ long.

Distribution. Sumatra (Lampung).

Habitat \& ecology. Montane forest in open places; 800-1200 m elevation.

Additional specimen examined. INDONESIA: Lampung: Mount Tanggamus, Gisting, $800 \mathrm{~m}$, Hughes et al. SUBOE 71 (BO, E).

Notes. This species resembles Macrolenes dimorpha from Peninsular Malaysia and Thailand in its indumentum on most parts, but differs in having bristle hairs that are covered with brown stellate hairs on the upper part with the base glabrous. The species is so far known only from Mount Tanggamus in Lampung Province, Sumatra.

\section{Macrolenes tuberculata Karton. sp. nov.}

Hypanthium tuberculate, cyathiform, rather short, slightly triangular to subrounded, calyx lobes c. 3.5 by $3 \mathrm{~mm}$, with acute to obtuse tips; similar in the size of the hypanthium and the length of the calyx lobes to Macrolenes bruneiensis, but differing in the type of the indumentum where M. tuberculata has tuberculate bristles and $M$. bruneiensis has floccose bristles. - TYPE: Indonesia, North Sumatra, Mount Leuser National Park, Besitang, Sikundur, 50-100 m alt., 8 August 1979, W.J.J.O. de Wilde \& B.E.E. de Wilde-Duyfjes 19573 (holotype BO; isotypes K, L). (Fig. 15-16)

Climbing up to $25 \mathrm{~m}$ high. Branchlets terete, 3-4 $\mathrm{mm}$ in diameter, covered with minute brown stellate-furfuraceous hairs; nodes swollen, with interpetiolar ridges; internodes $3.5-7 \mathrm{~cm}$ long. Leaves: petioles terete, $8-10 \mathrm{~mm}$ long, stellate-furfuraceous; blades elliptic-oblong to oblong, $5.5-13 \times 2-4.3 \mathrm{~cm}$, subcoriaceous, base slightly to broadly subcordate, margin entire, apex acuminate, acumen $0.5-1 \mathrm{~cm}$ long, adaxially glabrous, dark glossy green, abaxially densely stellate-tomentose. Inflorescences $3-5 \mathrm{~cm}$ long, with 1-3 flowers; main axis terete, densely brown stellate-furfuraceous; primary axis $1.5-2.5 \mathrm{~cm}$ long with 1 node, secondary axis when developed c. $0.7 \mathrm{~cm}$ long; bracts and bracteoles minute, caducous; pedicels densely brown stellate-furfuraceous, c. $5 \mathrm{~mm}$ long in central flowers, 2-3 mm long in lateral flowers. Hypanthium campanulate-cyathiform, c. $10 \times 6-8 \mathrm{~mm}$, densely covered with minute brown stellate-furfuraceous hairs and c. $0.5 \mathrm{~mm}$ long tubercles covered with minute brown stellate hairs; calyx lobes slightly triangular to subrounded with acute to obtuse tips, c. 3.5 by $3 \mathrm{~mm}$, densely covered with minute stellate hairs, reflexed. Petals in bud 

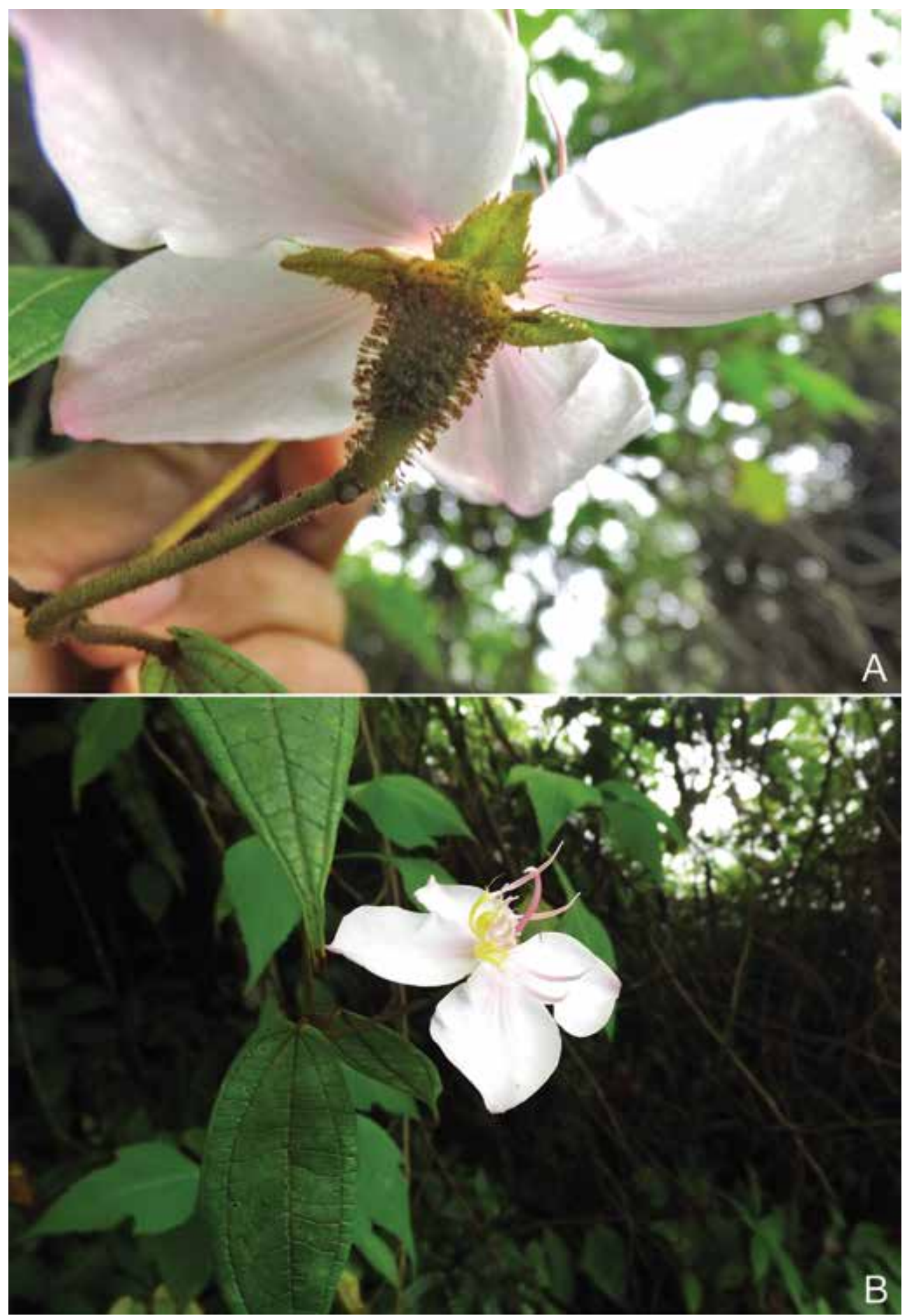

Fig. 14. Macrolenes subulata J.F.Maxwell. A. Hypanthium with mature flower. B. Flower (Photos: A. Kartonegoro). 


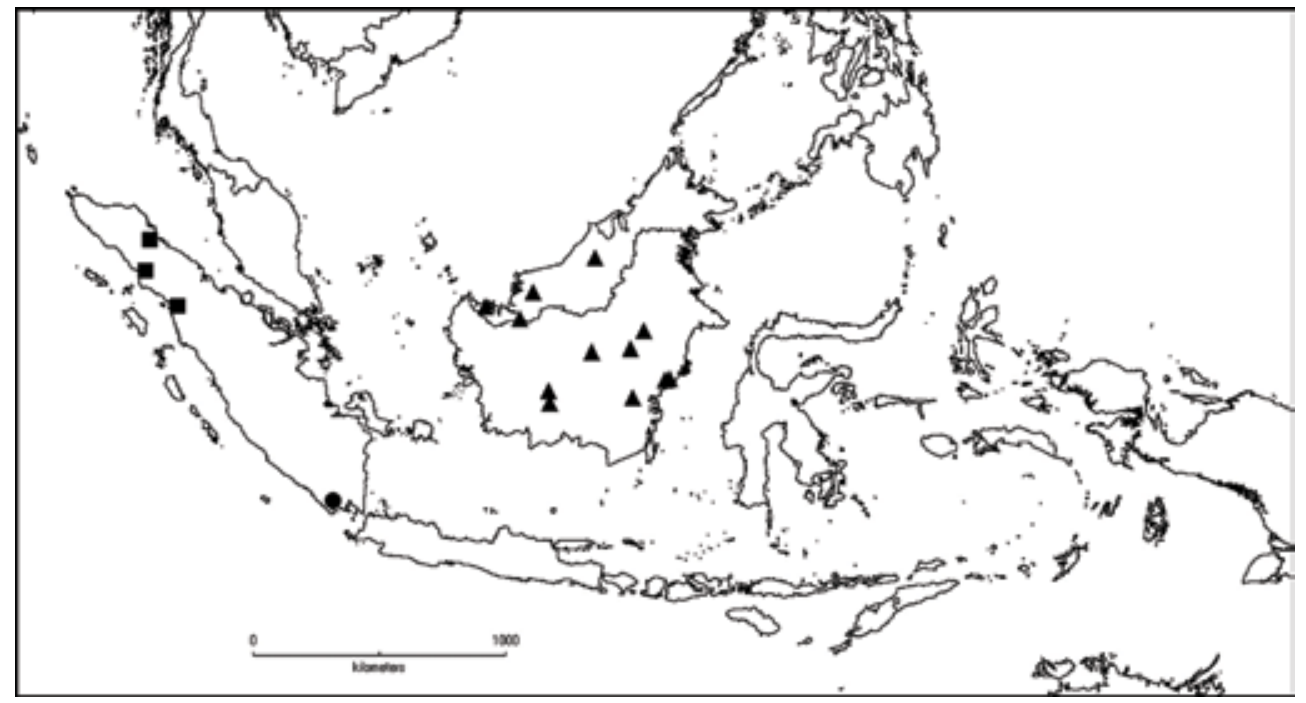

Fig. 15. Distribution of M. subulata J.F.Maxwell (•); M. tuberculata Karton. (घ); and $M$. veldkampii Karton. ( $\mathbf{\Delta})$.

conical, c. $5 \mathrm{~mm}$ long, brown stellate-tomentose; mature petals obovate to suborbicular, 8-12 × 6-10 mm, reflexed, base clawed, apex acute, above glabrous, underneath half glabrous, half densely brown stellate-tomentose, white to pinkish white. Stamens: alternipetalous stamens with c. $7 \mathrm{~mm}$ long yellowish filaments, anthers curved, sickle-shaped, thecae 10-11 mm long, pink, pedoconnective c. $4 \mathrm{~mm}$ long, connective basal crest thin, annular, prolonged into several fimbriate, filiform appendages, up to $3 \mathrm{~mm}$ long, lateral appendages not developed; oppositipetalous stamens with c. $6 \mathrm{~mm}$ long filaments, anthers S-shaped, thecae 8-9 mm long, pink, connective with a thin keel crest, c. $0.5 \mathrm{~mm}$ long, basally with paired, filiform lateral appendages, 5-6 mm long. Ovary $3 / 4$ as long as hypanthium, apex pubescent; style 12-13 mm long, densely stellate-pubescent, glabrous and curved at tip; stigma minute, capitate; extra-ovarial chambers extending to the middle of the ovary. Fruits ovoid, 10-12 × c. $9 \mathrm{~mm}$, densely covered with brown stellate hairs and small tubercles; calyx lobe remnants persistent, reflexed. Seeds c. $0.5 \mathrm{~mm}$ long.

Distribution. Sumatra (North).

Habitat \& ecology. Lowland tropical forest in open area or secondary logged forest at 50-250 m elevation.

Etymology. The species epithet refers to the tuberculate appearance of the hypanthium surface. 


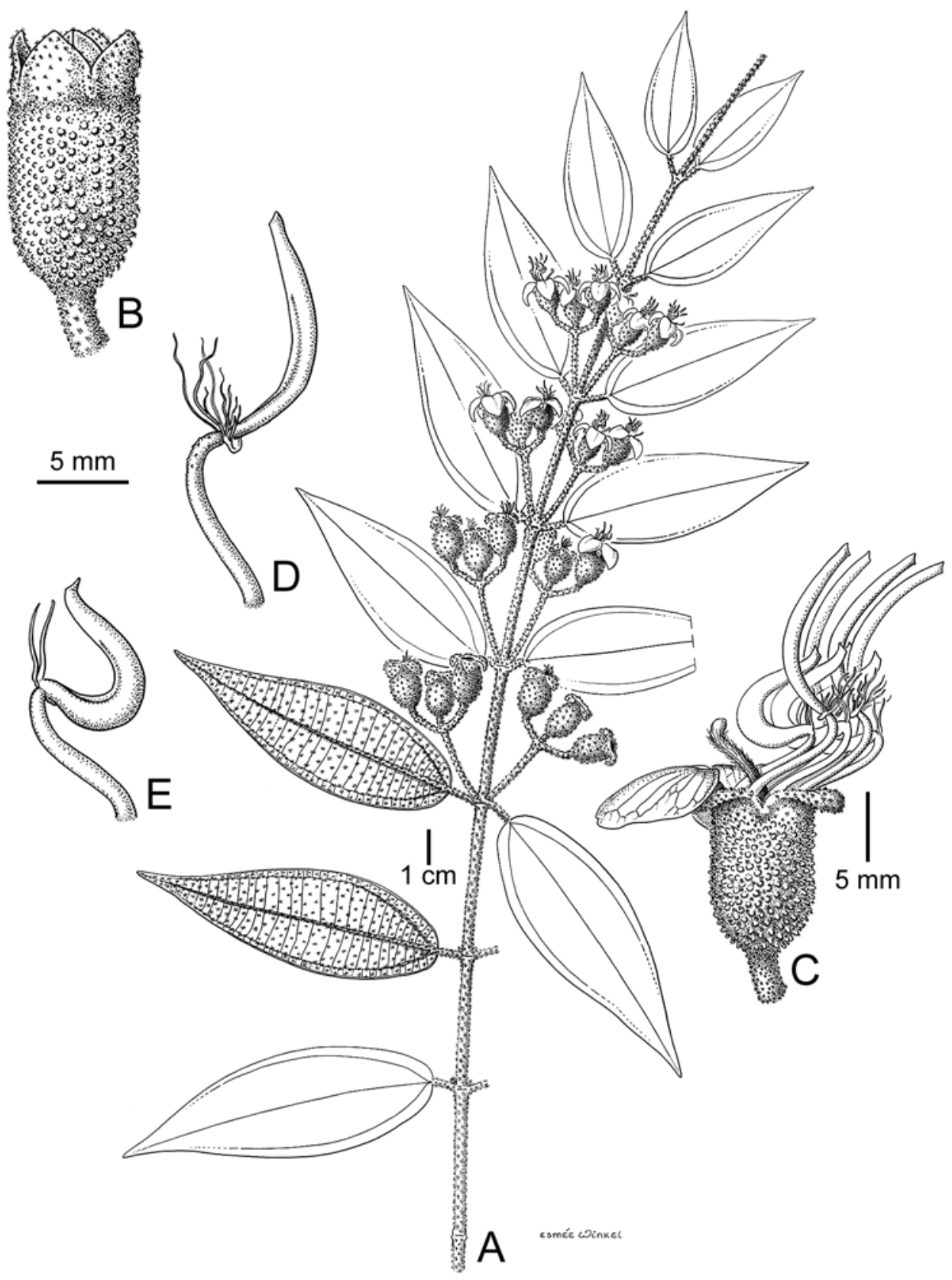

Fig. 16. Macrolenes tuberculata Karton. A. Habit. B. Hypanthium. C. Flower. D. Alternipetalous stamen. E. Oppositipetalous stamen. A, C-E from de Wilde \& de Wilde-Duyfjes 20667 (L); B from Maskuri 1103 (L). Drawn by Esmée Winkel. 
Additional specimens examined. INDONESIA: Aceh: Mount Leuser Nat. Park, Subulussalam, Alas River, Lae Batu-Batu, 50 m, 5 Aug 1985, de Wilde \& de Wilde-Duyfjes 20667 (L). North Sumatra: Mount Leuser Nat. Park, Besitang, Sikundur, 100-250 m, 15 Aug 1971, Iwatsuki et al. S-407 (BO, K, L); Ibid., 50 m, 29 Jan 1983, Maskuri 1103 (BO, K, L); Ibid., 20 Jul 1991, de Wilde \& de Wilde-Duyfjes 21086 (L, U).

Notes. Macrolenes tuberculata is recognised by its campanulate-cyathiform and tuberculate hypanthium. The tubercles (c. $0.5 \mathrm{~mm}$ long) on the hypanthium are covered by minute stellate hairs. Like M. bruneiensis, this species has a small hypanthium and short calyx lobes of only c. $3.5 \mathrm{~mm}$ long.

\section{Macrolenes veldkampii Karton., sp. nov.}

Resembles Macrolenes pachygyna in indumentum around the hypanthium of erect bristle hairs with barbed or branched tips, only the apex covered with dense, minute brown stellate hairs (the bristle hairs of $M$. pachygyna are completely covered with small brown stellate hairs). - TYPE: Indonesia, Borneo, East Kalimantan, Long Iram subdistrict, Maruwai, block Lampunut, 310 m, 004'S 11452'E, 19 March 1999, P.J.A. Kessler et al. 2656 (holotype BO; isotypes K, L [L0370302], WAN n.v.). (Fig. 15, 17)

Climbing up to $8 \mathrm{~m}$ high. Branchlets terete, 3-5 $\mathrm{mm}$ in diameter, densely covered with minute brown stellate-furfuraceous hairs; nodes swollen, with simple interpetiolar ridge; internodes 3.3-7 cm long. Leaves: petioles terete, 5-7 mm long, densely stellate-tomentose; blades ovate-elliptic, $6.5-8.4 \times 3-3.8 \mathrm{~cm}$, subcoriaceous, base cordate, margin entire, apex acuminate, acumen c. $0.5 \mathrm{~cm}$ long, adaxially glabrous, dark green, abaxially densely brown stellate-tomentose. Inflorescences 5.5-11 cm long, with 1-12 flowers; main axis terete or subangular, densely brown tomentose, often with scattered capitate bristle hairs; primary axis $2.5-7 \mathrm{~cm}$ long with 1 or 2 nodes, secondary axis $0.8-2.4 \mathrm{~cm}$ long with 1 node or not developed, tertiary axis if developed up to $1.7 \mathrm{~cm}$ long; bracts linear or lanceolate, $7-8 \times$ c. $2 \mathrm{~mm}$, entire, stellate-tomentose outside, glabrous inside, caducous; bracteoles linear or lanceolate, 4-5 mm long, stellate-tomentose outside, glabrous inside; pedicels densely covered with minute stellate-furfuraceous hairs and bristle hairs covered with dense minute stellate hairs at tip, tip appearing to be capitate, 2-3 $\mathrm{mm}$ long in central and lateral flowers. Hypanthium campanulate, 9-12 × 7-9 $\mathrm{mm}$, brownish when dry, densely covered (surface of hypanthium not visible) with c. $2 \mathrm{~mm}$ long erect bristle hairs with barbed or branched tips, latter covered with dense minute brown stellate hairs, base of bristles glabrous or subglabrous; calyx lobes triangular with acute tips, 5-6 $\times 3-4 \mathrm{~mm}$, densely covered with bristle hairs as on hypanthium, margin ciliate and covered with minute brown stellate hairs. Petals in bud conical, 5-6 mm long, covered with stellate-furfuraceous hairs; mature petals obovate to suborbicular, 15-18 $\times 8-10$ $\mathrm{mm}$, not reflexed, base clawed, apex obtuse, above glabrous, underneath half stellate- 


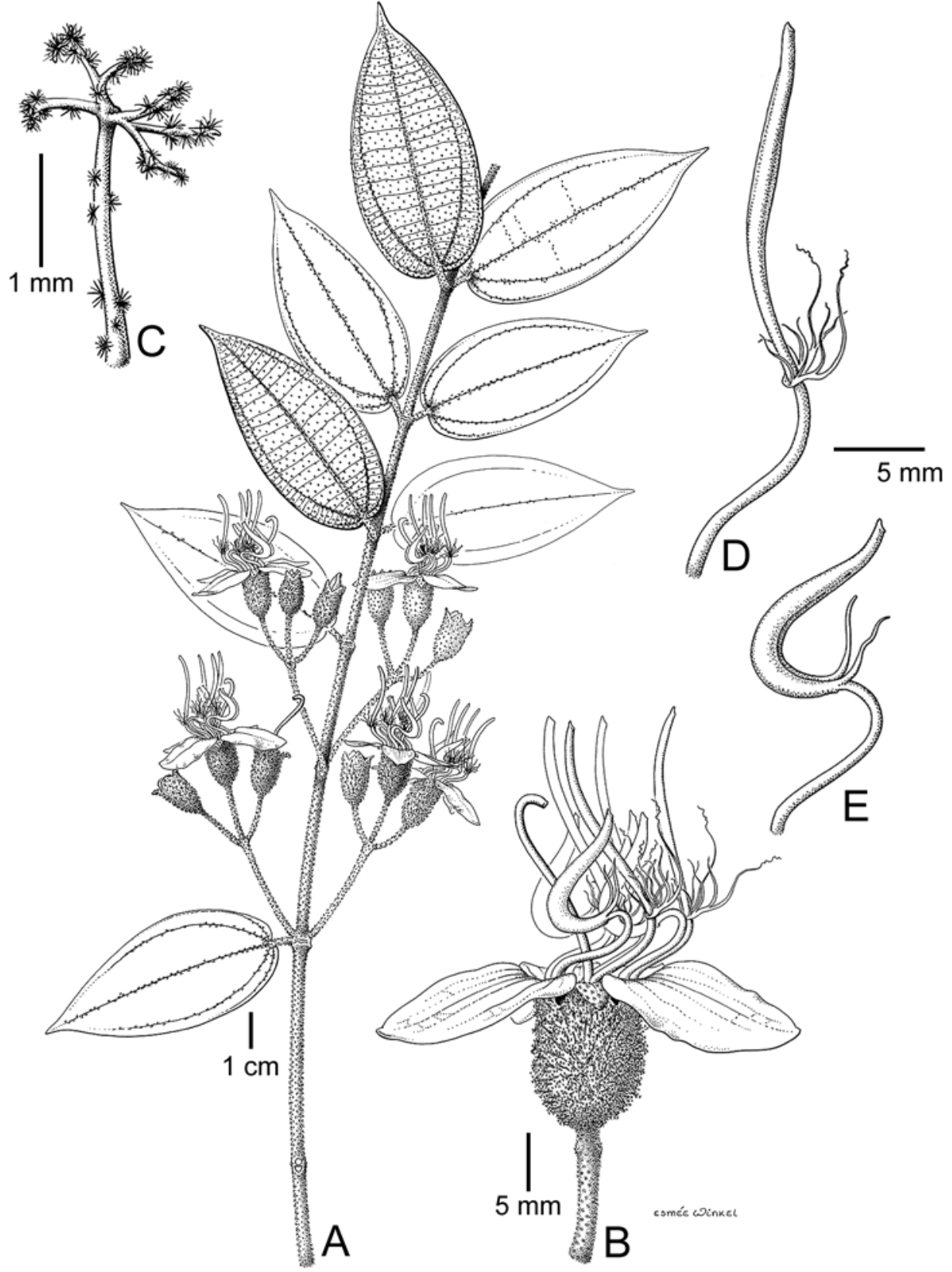

Fig. 17. Macrolenes veldkampii Karton. A. Habit. B. Flowers. C. Indumentum. D. Alternipetalous stamen. E. Oppositipetalous stamen. All from Kostermans 13041 (L). Drawn by Esmée Winkel. 
furfuraceous, half glabrous. Stamens: alternipetalous stamens with c. $6 \mathrm{~mm}$ long filaments, anthers curved, sickle-shaped, thecae 15-16 mm long, pedoconnective 4-5 $\mathrm{mm}$ long, connective basal crest thin, annular, prolonged into several fimbriate, filiform appendages, 5-6 mm long, lateral appendages not developed; oppositipetalous stamens with c. $6 \mathrm{~mm}$ long filaments, anthers S-shaped, thecae 9-11 $\mathrm{mm}$ long, connective with a minute thin keel crest, c. $0.3 \mathrm{~mm}$ long, basally with paired, filiform lateral appendages, 5-6 mm long. Ovary $3 / 4$ as long as hypanthium, apex pubescent; style 15-16 mm long, stellate-furfuraceous and with scattered capitate bristle hairs, above glabrous, curved at tip; stigma minute, capitate; extra-ovarial chambers extending almost to base of ovary. Fruits urceolate, 10-12 $\times 8-9 \mathrm{~mm}$, brown, densely covered with c. $2 \mathrm{~mm}$ long erect bristle hairs with barbed or branched tips, latter covered with dense minute brown stellate hairs, base of bristles glabrous or subglabrous; calyx lobe remnants persistent, reflexed. Seeds c. $0.75 \mathrm{~mm}$ long.

Distribution. Borneo.

Habitat \& ecology. Secondary lowland or mixed dipterocarp forest, sometimes waterlogged; 50-600 m elevation.

Etymology. The species epithetacknowledges the late Jan Frederik "Jan Frits"Veldkamp, a Dutch agrostologist, who also worked on Southeast Asian Melastomataceae (for obituary see Baas \& Hovenkamp, 2018a, 2018b).

Additional specimens examined. INDONESIA: Central Kalimantan: Kuala Kuayan, Permantang, 50 m, 30 Mar 1984, Hansen 1318 (BO); Barito Ulu, 2 Jun 1990, Ridsdale PBU 275 (BO, K, L); Ibid., 26 May 1990, Sidiyasa PBU 132 (BO, L); Kotawaringin Timur, Sangai, 50 m, 21 Sep 1996, Argent \& Wilkie 963 (L). East Kalimantan: Ambriansyah \& Arifin W 217 (L); Long Iram, Maruwai, Lampunut, 310 m, 20 Mar 1999, Kessler et al. 2676 (BO, K, L); Mount Palimasan, 600 m, 14 Sep 1956, Kostermans 13041 (BO, K, L); Bukit Bangkirai, 17 Feb 2001, Ruskandi \& Rugayah 400 (BO). South Kalimantan: Tabalong, 190 m, 5 Jul 2000, Sidiyasa \& Arifin 2007 (BO, L).

MALAYSIA: Sarawak: Baram, Ulu Tinjar, Mount Dulit, 13 Sep 1932, Richards 1770 (K); Kuching, Bartlett s.n. (BM); Ibid., Beccari PB 125 (K, P); Ibid., Beccari PB 379 (K, P); Ibid., Beccari PB 632 (K, P); Pengkulu Ampat, 31 Oct 1890, Haviland 147 (BM, K); Sri Aman, Kampong Pungur Tapang, 5 Nov 1980, Paie S.42719 (K, L).

Notes. The bristles on the hypanthium have a branched and barbed apex, in which Macrolenes veldkampii resembles M. pachygyna, but the bristles are only covered by minute stellate hairs in the upper part, while the base is glabrous. The bristle hairs are also present on the pedicels and the calyx lobes, whereas Macrolenes pachygyna has no bristle hairs here. 


\section{Excluded taxa}

Macrolenes griffithii M.P.Nayar, J. Jap. Bot. 55: 47 (1980). - TYPE: Malaysia, Peninsular Malaysia, Malacca, W. Griffith KD 2269 (holotype K [K001096571]). = Dissochaeta griffithii (M.P.Nayar) Karton., PhytoKeys 107: 91 (2018).

Macrolenes horrida Bakh.f., Contr. Melastom. 208 (1943). - TYPE: Indonesia, West Sumatra, Agam, Brani, H.A.B. Bünnemeijer 3200 (holotype L [L0537276]; isotypes BO [BO1751324, BO1751325]).=Dissochaeta horrida (Bakh.f.) Karton., PhytoKeys 107: 95 (2018).

Macrolenes ruttenii Bakh.f., Contr. Melastom. 210 (1943). - TYPE: Indonesia, East Kalimantan, Samarinda, Bengalon, L.M.R. Rutten 535 (holotype U [U0004012]). = Dissochaeta rostrata Korth. in Temminck, Verh. Nat. Gesch. Ned. Bezitt., Bot. 239 (1844).

Marumia warburgii Cogn. in Warburg, Bot. Jahrb. Syst. 13: 393 (1891) and in de Candolle \& de Candolle, Monogr. Phan. 7: 554 (1891). - TYPE: Papua New Guinea, Sattelberg, O. Warburg 30 (lectotype BR [BR528055], designated here; isolectotype B n.v.). = Rhodomyrtus trineura (F.Muell.) F.Muell. ex Benth. var. novoguineensis (Diels) A.J.Scott, Kew Bull. 33: 324 (1978) (Myrtaceae).

ACKNOWLEDGEMENTS. The authors wish to thank the directors and curators of the following herbaria (abbreviations following Thiers 2018) for permission to examine and view specimens: AAU, ANDA, BK, BM, BO, BR, E, G, K, KEP, L, M, P, PE, PNH, SING and U. The initial research was supported by the Research and Innovation in Science and Technology Project (RISET-Pro) of the Ministry of Research, Technology and Higher Education of the Republic of Indonesia (World Bank Loan No. 8245-ID). Additional funding for this project, including the field work, was provided by the following: the Bentham-Moxon Trust Grant of the Royal Botanic Gardens Kew (RBGK), UK, for herbarium visit to K; Swaantje Mondt Fund of Leids Universiteits Fonds (LUF), Leiden University, for field work in Indonesia. The last author $(\mathrm{PvW})$ thanks the Treub Maatschappij, the Society for the Advancement of Research in the Tropics, for their support of the Ornstein chair in Tropical Plant Biogeography. Collecting permits were granted by the West Sumatra Nature Conservation Agency (BKSDA) and Mount Halimun-Salak National Park (TNGHS) of the Ministry of Environment and Forestry, Republic of Indonesia; shipping permits by Research Center for Biology (LIPI), Bogor and Quarantine Agency of the Ministry of Agriculture, Republic of Indonesia. Furthermore, we thank Esmée Winkel (Naturalis Biodiversity Center, Leiden) who prepared the drawings of the new taxa in this manuscript. We are also grateful that Cerlin $\mathrm{Ng}$ and Zakaria $\mathrm{Al}$ Anshori allowed us to reproduce their photographs of Macrolenes. Last, we are also grateful to Prof. Dr. Susanne Renner (M) and Prof. Dr. Anton Weber (WU) for their valuable comments, corrections and suggestions to the manuscript during the review process. 


\section{References}

Baas, P. \& Hovenkamp, P.H. (2018a). In memoriam Jan-Frits Veldkamp (31 March 1941 - 12 November 2017). Blumea 63: 1-10.

Baas, P. \& Hovenkamp, P.H. (2018b). Obituary: Jan Frits Veldkamp (1941-2017). Sibbaldia 16: 5-6.

Backer, C.A. (1936). Verklarend woordenboek van wetenschappelijke plantennamen. Gronigen: Noordhoff N.V.

Bakhuizen van den Brink, R.C. (1943). A contribution to the knowledge of the Melastomataceae occurring in the Malay Archipelago, especially in the Netherlands East Indies. PhD thesis, Universiteit Utrecht. Reprinted in: Recueil Trav. Bot. Néerl. 40: 1-391 (1946); Meded. Bot. Mus. Herb. Rijks Univ. Utrecht 91: 1-391 (1947).

Bentham, G. \& Hooker, J.D. (1867). Genera Plantarum, vol. 1. London: L. Reeve \& Co.

Blume, C.L. (1823). Catalogus van eenige der merkwaardigste zoo in-als uit-heemsche gewassen te vinden in 's Lands Plantentuin te Buitenzorg. Batavia: Lands Drukkerij.

Blume, C.L. (1831). Ueber einige Ostindische und besonders Javanische Melastomaceen. Flora 14: 465-528.

Clarke, C.B. (1879). Melastomaceae. In: Hooker, J.D. (ed.) The Flora of British India, vol. 2, pp. 512-565. London: L. Reeve \& Co.

Clausing, G. \& Renner, S.S. (2001). Evolution of growth form in epiphytic Dissochaeteae (Melastomataceae). Organisms Diversity Evol. 1: 45-60.

Clausing, G., Meyer, K. \& Renner, S.S. (2000). Correlations among fruit traits and evolution of different fruits within Melastomataceae. Bot. J. Linn. Soc. 133: 303-326.

Cogniaux, A. (1890). Melastomaceae. In: Boerlage, J.G. (ed.) Handleiding tot de kennis der flora van Nederlandsch Indië, vol. 2, pp. 500-538. Leiden: EJ Brill.

Cogniaux, A. (1891). Melastomaceae. In: Candolle, A. de \& Candolle, C. de (eds) Monographiae Phanerogamarum, vol. 7, pp. 1-1256. Paris: G. Masson.

Craib, W.G. (1931). Florae Siamensis enumeratio. A list of the plants known from Siam, vol. 10. Bangkok: Bangkok Times Press Ltd.

Furtado, C.X. (1963). Notes on some Malaysian Melastomaceae. Gard. Bull. Singapore 20: $105-122$.

Jack, W. (1823). On the Malayan species of Melastoma. Trans. Linn. Soc. London 14: 1-22.

Kadereit, G. (2006). A new species of Dissochaeta Blume (Melastomataceae) from Kalimantan (Borneo, Indonesia). Edinburgh J. Bot. 63: 3-8.

Kartonegoro, A. \& Veldkamp, J.F. (2010). Revision of Dissochaeta (Melastomataceae) in Java, Indonesia. Reinwardtia 13: 125-145.

Kartonegoro, A. \& Veldkamp, J.F. (2013). Revision of Creochiton (Melastomataceae). Blumea 58: 217-227.

Kartonegoro, A., Veldkamp, J.F., Hovenkamp, P. \& Van Welzen, P.C. (2018). A Revision of Dissochaeta (Melastomataceae, Dissochaeteae). PhytoKeys 107: 1-178.

King, G. (1900). Materials for a flora of the Malayan Peninsula 1. J. Asiat. Soc. Bengal, Pt. 2, Nat. Hist. 69(2): 1-87.

Korthals, P.W. (1842-1844). Melastomaceae. In: Temminck, C.J. (ed.) Verhandelingen over de natuurlijke geschiedenis der Nederlandsche overzeesche bezittingen, Botanie, vol. 7, pp. 236-243. Leiden: Natuurkundige Commissie.

Krasser, F. (1893). Melastomataceae. In: Engler, A. \& Prantl, K. (eds) Die natürlichen Pflanzenfamilien, vol. 3, abt. 7, pp. 130-199. Leipzig: Engelmann. 
Maxwell, J.F. (1980a). Taxonomic revision of Diplectrinae Maxw. and Dissochaetinae Naud. (Dissochaeteae) Melastomataceae. PhD thesis, University of Singapore.

Maxwell, J.F. (1980b). Taxonomic notes on the tribe Dissochaeteae (Naudin) Triana (Melastomataceae). Gard. Bull. Singapore 33: 312-327.

Maxwell, J.F. (1984). Taxonomic studies of the Melastomataceae (Part 1). A revision of subtribes Dissochaetinae Maxw. and Dissochaetinae Naudin (genera Diplectria (B1.) Reichb., Dissochaeta B1., Macrolenes Naudin, Creochiton B1., and Pseudodissochaeta Nayar). Fed. Mus. J. 29: 45-117.

Miquel, F.A.W. (1855). Flora van Nederlandsch Indië, vol. 1. Amsterdam: C.G. van der Post.

Naudin, C. (1851). Melastomacearum quae in Museo parisiensi continentur monographicae descriptiones et secundum affinitates distributionis tentamen. Ann. Sci. Nat., Bot. sér. 3, 15: 277-283.

Nayar, M.P. (1980). Notes on Asian Melastomataceae 3. New species and notes on the genus Macrolenes Naud. J. Jap. Bot. 55: 45-52.

Nees von Esenbeck, T.F.L. (1825). Catalogus van eenige der merkwaardigste zoo in- als uitheemse gewassen te vinden in 's Lands Plantentuin te Buitenzorg opgemaakt door C. L. Blume. Flora 8: 97-160.

Reinwardt, C.G.C. (1828). Nova plantarum indicarum genera. In: Hornschuch, C.F. (ed) Sylloge Plantarum Novarum Itemque Minus Cognitarum a Praestantissimis Botanicis adhuc Viventibus Collecta et a Societate Regia Botanica Ratisbonensi, edita 2. Regensburg: C.E. Brenck.

Renner, S.S. (1993). Phylogeny and classification of the Melastomataceae and Memecylaceae. Nordic J. Bot. 13: 519-540.

Renner, S.S., Clausing, G., Cellinese, N. \& Meyer, K. (2001). Melastomataceae. In: Santisuk, T. \& Larsen, K. (eds) Flora of Thailand, vol. 7, part. 3, pp. 412-497. Bangkok: The Forest Herbarium, Royal Forest Department.

Ridley, H.N. (1922). The Flora of the Malay Peninsula, vol. 1. London: L. Reeve \& Co.

Thiers, B. (2018, continously upadated). Index Herbariorum: A global directory of public herbaria and associated staff. New York Botanical Garden's Virtual Herbarium. http:// sweetgum.nybg.org/science/ih/. Accessed 13 Feb. 2018.

Triana, J. (1872 ['1871']). Les Mélastomacées. Trans. Linn. Soc. London 28: 1-188.

Turland, N.J., Wiersema, J.H., Barrie, F.R., Greuter, W., Hawksworth, D.L., Herendeen, P.S., Knapp, S., Kusber, W.-H., Li, D.-Z., Marhold, K., May, T.W., McNeill, J., Monro, A.M., Prado, J., Price, M.J. \& Smith, G.F. (2018). International Code of Nomenclature for algae, fungi, and plants (Shenzhen Code). Regnum Vegetabile 159. Glashütten: Koeltz Botanical Books.

Turner, I.M. (2018). The importance of the plates in the Verhandelingen over de natuurlijke geschiedenis der Nederlandsche overzeesche bezittingen, Botanie for the nomenclature of South-East Asian plants. Taxon 67(3): 621-631.

Veldkamp, J.F. (1979 ['1978']). Notes on Creochiton, Dissochaeta, and Macrolenes (Melastomataceae). Blumea 24: 437-446.

Veldkamp, J.F., Franken, N.A.P., Roos, M.C. \& Nayar, M.P. (1979 ['1978']). A revision of Diplectria (Melastomataceae). Blumea 24: 405-430.

Ventenat, E.P. (1803). Choix de plantes. Paris: Láuteur.

Wong, K.M. (2016). The genus Melastoma in Borneo including 31 new species. Kota Kinabalu: Natural History Publication. 